UNIVERSIDAD POLITÉCNICA DE VALENCIA

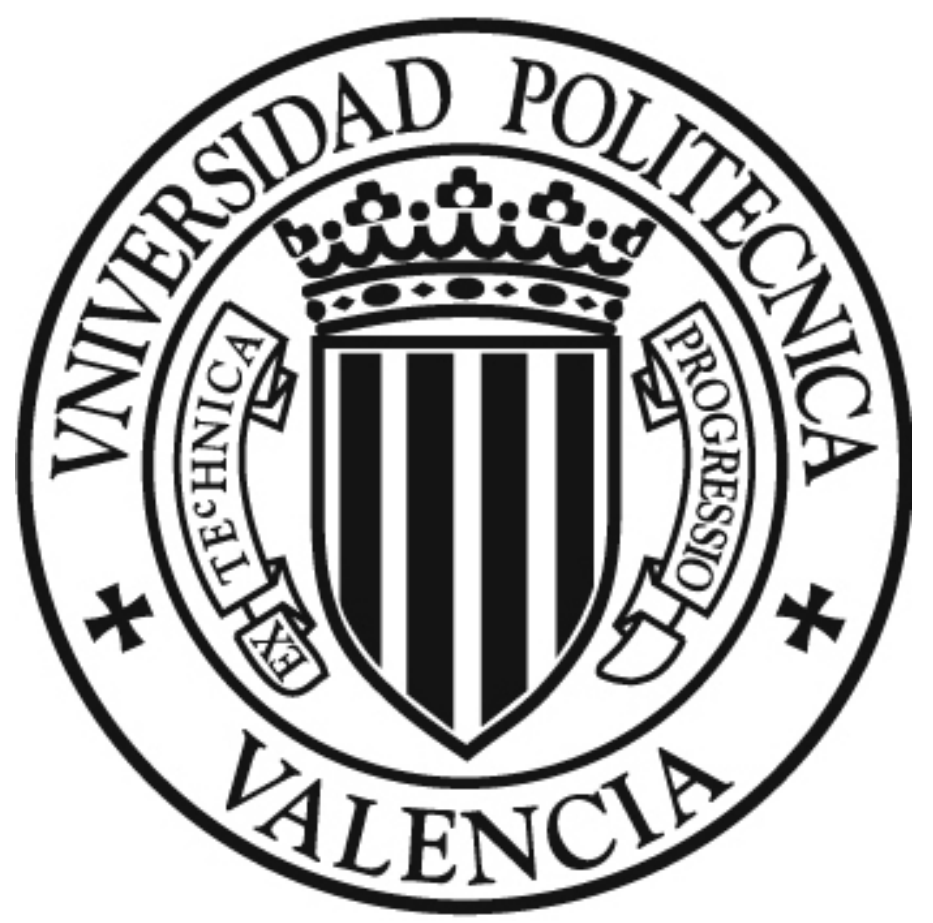

Co-creation innovation for business programs for educational institutions

TESIS DOCTORAL

Doctorando:

Don Agustín Peralt Rillo

Dirigida por:

Dra Dña. Gabriela Ribes Giner

Valencia, Febrero 2015 


\section{Resumen}

En la actualidad, las universidades se encuentran con una competencia cada vez mayor en lo que se refiere a sus programas de posgrado. A la vez que se incrementa la oferta por parte de las instituciones educativas, impera la necesidad por parte de las universidades de mejorar su conocimiento sobre el mercado de posgrado, debido a la falta de investigación existente con una literatura sobre marketing escasa. Todo ello, ayudará a las instituciones educativas a desarrollar estrategias competitivas adecuadas para lograr atraer el talento de los estudiantes de posgrado diferenciándose de la competencia.

Esto supone, por parte de las universidades, la necesidad de desarrollar una orientación proactiva hacia el mercado como inicio de esta estrategia de diferenciación. Además, esta orientación proactiva al mercado, tendrá una particularidad en el caso de los programas de posgrado: no solamente deberá considerar al estudiante adulto, sino también a las propias empresas, ya que en ocasiones son ellas las que apuestan por esos programas al enviar a sus propios profesionales.

Esta orientación proactiva el mercado, pasará, como en otros muchos mercados, por apostar por políticas de marketing de éxito, que permitan en un sentido o en otro, innovar y diferenciarse. Al mismo tiempo, son muchos los autores que relacionan esa orientación proactiva al mercado, con la cocreation. En el caso específico del sector educativo, la co-creation se ha estudiado poco y siempre desde una perspectiva de estudiantes universitarios, no de posgrado. Por último, las consecuencias en el alumno de posgrado de participar en estos procesos de co-creation desde el punto de vista de los efectos en su satisfacción y lealtad, es algo que tampoco se ha estudiado.

Así en primer lugar, en esta tesis, se realiza una revisión bibliográfica de los conceptos de "orientación proactiva hacia el mercado" así como el "proceso de compra" de un programa de posgrado por parte del estudiante adulto.

En esta fase se plantea un primer modelo innovador que describe "el proceso de compra del estudiante adulto" que será el marco perfecto que facilitará las diferentes reflexiones sobre universidades, alumnos adultos y empresas y todas sus interacciones.

En el segundo estudio, se introduce el concepto de co-creation a través también de una revisión profunda de los conceptos de innovación basada en la co-creación y la innovación educativa. Se plantea un nuevo modelo completada, basada en el inicial, con la introducción del concepto de cocreación. Este modelo será testado a través de un estudio Delphy de expertos introduciendo las mejoras consideradas 
La siguiente etapa de nuestra tesis prosiguió con el objetivo de profundizar cuales serían las mejores técnicas y herramientas para poder implementar con éxito la co-creación. Con una revisión exhaustiva de las distintas técnicas utilizadas en otros sectores se realiza una clasificación de las mismas, en función de las dimensiones conceptuales de la co-creation.

Tras una revisión de las mismas, y considerando las particularidades del sector educativo de posgrado, es precisamente el living lab el que mejor representa ese proceso de trabajar la co-creation pues simula ese proceso de trabajar en situaciones y entornos reales de trabajo. Al mismo tiempo y dada la particularidad del proceso de compra de un master, consideramos que el involucramiento de Lead Users es algo que también se debe considerar.

En la última etapa, nuestra investigación tiene como objetivo medir empíricamente el impacto y las consecuencias de la co-creación en la satisfacción y lealtad del estudiante de posgrado hacia la institución educativa que le facilita participar en esta co-creation. Las relaciones propuestas son consecuencia de una revisión de la literatura cuya consecuencia es un modelo de ecuaciones estructurales (SEM) donde se comprueban estas relaciones hipotéticas entre la co-creacion y la satisfacción y lealtad por parte del estudiante hacia la universidad. Del análisis de la información se puede concluir que la participación del alumno en la co-creation con la universidad, lleva a niveles mayores de satisfacción, y a una mayor lealtad.

Este primer estudio cuantitativo ha supuesto una validación del modelo propuesto, por lo que se puede afirmar, que con independencia de los resultados obtenidos en el proceso de co-creation, el propio proceso de involucración del alumno en ello, redundará en una mayor satisfacción y lealtad hacia la institución. Por todo ello, la co-creation puede facilitar que las instituciones educativas desarrollen estrategias competitivas diferenciadoras que generarán tanto una mayor satisfacción para el estudiante como la posibilidad de lograr diferenciación gracias la innovación que surja del mismo.

Con posterioridad a este primer estudio cuantitativo, se realiza un segundo estudio si bien desde un contexto Business to Business al pretender medir las consecuencias de la co-creation en la satisfacción, fortaleza de la relación y lealtad del estudiante, en este caso profesional enviado por la empresa, hacia la institución educativa. Este nuevo modelo de ecuaciones estructurales (SEM) es más amplio en variables y relaciones que el anterior, introduciendo la fortaleza de la relación. Además se centra en estudiantes adultos que en este caso son profesionales enviados por sus empresas a realizar el programa master, vertiente Business to Business frente a Business to Consumer del anterior

Las conclusiones del estudio son que la co-creation donde el estudiante adulto participa en el proceso, lleva a niveles más altos de satisfacción y a una mayor lealtad hacia la institución educativa. Al mismo tiempo, nuestra investigación muestra, que la fortaleza en la relación, está influenciada positivamente por este proceso de creación de valor si bien no media entre la co-creation y la lealtad. En este caso, la investigación sólo ha validado parte del 
modelo. Así, esta parte última de nuestra investigación vuelve a ser una reafirmación de la idea de que la co-creation puede ser, en sí misma, una herramienta beneficiosa para las universidades para desarrollar estrategias competitivas que generen más valor para sus clientes y que también sea difícil de imitar por la competencia

Finalmente señalar que los resultados de este trabajo facilitan la implementación de un proceso de co-creation entre universidades y estudiante de posgrado así como las posibles áreas de aplicación de la misma dentro del proceso de compra y elección de un programa master. Por otra parte, también se ha demostrado, que con independencia de los resultados de este proceso, la co-creación en si misma resulta en mayores tasas de satisfacción, mejora en la fortaleza en la relación y mayor lealtad hacia la institución por parte del alumno. 


\section{Resum}

Actualment, les universitats es troben amb una competència cada vegada més gran pel que fa als seus programes de postgrau. Alhora que s'incrementa l'oferta per part de les institucions educatives, impera la necessitat per part de les universitats de millorar el seu coneixement sobre el mercat de postgrau, a causa de la falta d'investigació existent amb una literatura sobre màrqueting escassa. Tot això, ajudarà a les institucions educatives a desenvolupar estratègies competitives adequades per aconseguir atreure el talent dels estudiants de postgrau diferenciant-se de la competència.

Això suposa, per part de les universitats, la necessitat de desenvolupar una orientació proactiva cap al mercat com a inici d'aquesta estratègia de diferenciació. A més, aquesta orientació proactiva al mercat, tindrà una particuliradiad en el cas dels programes de postgrau: no sols ha haurà de considerar l'estudiant adult, sinó també a les pròpies empreses, ja que en ocasions són elles les que aposten per aquests programes al enviar els seus propioso professionals.

Aquesta orientació proactiva el mercat, passarà, com en molts altres mercats, per apostar per polítiques de màrqueting de éxitoexitosas, que permetin en un sentit o en un altre, innovar i diferenciar-se. Alhora, són molts els autors que relacionen aquesta orientació proactiva al mercat, amb la cocreation. En el cas específic del sector educatiu, la co-creation s'ha estudiat poc i sempre des d'una perspectiva d'estudiants universitaris, no de postgrau. Finalment, les conseqüències en l'alumne de postgrau de participar en aquests processos de co-creation des del punt de vista dels efectes en la seva satisfacció i lleialtat, és una cosa que tampoc s'ha estudiat.

Així en primer lloc, en aquesta tesi, es realitza una revisió bibliogràfica dels conceptes de "orientació proactiva cap al mercat" així com el "procés de compra" d'un programa de postgrau per part de l'estudiant adult.

En aquesta primera fase es planteja un primer model innovador que descriu "el procés de compra del estudante adult" que serà el marc perfecte que facilitarà les diferents reflexions sobre universitats, alumnes adults i empreses i totes les seves interaccions.

En el segon estudi, s'introdueix el concepte de co-creació a través també d'una revisió profunda dels conceptes d'innovació basada en la co-creació i la innovació educativa. Es planteja un nou model completada, basada en l'inicial, amb la introducció del concepte de co-creació. Aquest model serà testat a través d'un estudi Delphy d'experts introduint les millores considerades 
La següent etapa de la nostra tesi va prosseguir amb l'objectiu d'aprofundir quines serien les millors tècniques i eines per poder implementar amb èxit la co-creació. Amb una revisió exhaustiva de les diferents tècniques utilitzades en altres sectors re realitza una classificació de les mateixes, en funció de les dimensions conceptuals de la co-creation.

Després d'una revisió de les mateixes, i considerant les particularitats del sector educatiu de postgrau, és precisament el living lab el que millor representa aquest procés de treballar la co-creatcion doncs simula aquest procés de trabajr en situacions i entorns reals de treball. Al mateix temps i atesa la particularitat del procés de compra d'un màster, considerem que la implicació de Lead Users és una cosa que també s'ha de considerar.

En l'última etapa, la nostra investigació té com a objectiu mesurar empíricament l'impacte i les conseqüències de la co-creació en la satisfacció i lleialtat del estudiant de postgrau cap a la institució educativa que li facilita participar en aquesta co-creatción. Les relacions propostes són conseqüència d'una revisió de la literatura la conseqüència és un model d'equacions estructurals (SEM) on es comproven aquestes relacions hipotètiques entre la co-creació i la satisfacció i lleialtat per part de l'estudiant cap a la universitat. De l'anàlisi de la informació es pot concloure que la participació de l'alumne en la co-creation amb la universitat, porta a nivells majors de satisfacció, ia una major lleialtat.

Aquest primer estudi quantitatiu ha suposat una validació del model proposat, de manera que es pot afirmar, que amb independència dels resultats obtinguts en el procés de co-creation, el mateix procés d'involucració de l'alumne en això, redundarà en una major satisfacció i lleialtat cap a la institució. Per tot això, la co-creation pot facilitar que les institucions educatives desenvolupin estratègies competitives diferenciadores que generaran tant una major satisfacció per a l'estudiant com la possibilitat d'aconseguir diferenciació gràcies la innovació que sorgeixi de ell mateix.

Amb posterioritat a aquest primer estudi quantitatiu, es realitza un segon estudi si bé des d'un context Business to Business en pretendre mesurar les conseqüències de la co-creation a la satisfacció, fortalesa de la relació i lleialtat de l'estudiant, en aquest cas professional enviat per l'empresa, cap a la institució educativa. Aquest nou model d'equacions estructurals (SEM) és més ampli en variables i relacions que l'anterior, introduint la fortalesa de la relació. A més se centra en estudiants adults que en aquest cas són professionals enviats per les seves empreses a realitzar el programa màster, vessant Business to Business davant Business to Consumer l'anterior

Les conclusions de l'estudi són que la co-creation on l'estudiant adult participa en el procés, porta a nivells més alts de satisfacció ia una major lleialtat cap a la institució educativa. Alhora, la nostra investigació mostra, que la fortalesa en la relació, està influenciada positivament per aquest procés de creació de valor si bé no hi ha entre la co-creation i la lleialtat. En aquest cas, la investigació només ha validat part del model. Així, aquesta part última de la nostra recerca torna a ser una reafirmació de la idea que la co-creation pot ser, 
en si mateixes, una eina beneficiosa per a les universitats per desenvolupar estratègies competitives que generin més valor per als seus clients i que també sigui difícil d'imitar per la competència

Finalment assenyalar que els resultats d'aquest treball faciliten la implementació d'un procés de co-creation entre universitats i estudiant de postgrau així com les possibles àrees d'aplicació de la mateixa dins del procés de compra i elecció d'un programa màster. D'altra banda, també s'ha demostrat, que amb independència dels resultats d'aquest procés, la co-creació en si mateixa resulta en majors taxes de satisfacció, millora en la fortalesa en la relació i major lleialtat cap a la institució per part de l'alumne. 


\begin{abstract}
Nowadays, universities are finding they have more and more competition regarding postgraduate programs. As educational institutions increase the offer, the need for them to improve their knowledge about the postgraduate market becomes more evident due to the lack of existing research and scarce literature about the topic. All this will help the educational institutions to develop suitable competitive strategies in order to attract postgraduate students' talent, thus distinguishing the institutions from the competition.
\end{abstract}

This implies, on behalf of the universities and in order to initiate this differentiation strategy, the need to develop a proactive orientation towards the market. Besides, this proactive orientation towards the market, in the case of postgraduate programs, will have a peculiarity: it will not only have to take into consideration the adult student, but also companies, being that at times it is the companies that confide in these programs to send their professionals.

This proactive orientation towards the market wills, like in many other markets, end up confiding in those programs which have successful marketing and allow for innovation and differentiation. At the same time, many authors relate this proactive orientation towards the market to co-creation. More specifically in the education sector, co-creation has been researched very little and has always been focused on the undergraduate student, not postgraduate. Lastly, the consequences of the postgraduate students' participation in these co-creation processes concerning satisfaction and loyalty is something that has not been studied either.

Therefore, firstly, a bibliographic review of the concepts of "proactive orientation towards the market" is carried out as well as the "purchase process" of a postgraduate program by an adult student.

In this first phase the first innovative model is raised which describes "the purchase process by the adult student" and which will be the perfect frame for the different reflections about universities, adult students and companies and all their interactions.

In the second study, the concept of co-creation is also introduced through an in-depth review of the concepts of innovation based on co-creation and educational innovation. A new completed model is raised based on the first one, with an introduction of the concept of co-creation. This model will be tested by a Delphy study performed by experts and which includes proposed improvements.

The next phase of our study continues with the aim of looking at greater depth which would be the best techniques and tools to implement successfully co-creation. With an exhaustive review of the different techniques used in other sectors, a classification is done on them in relation to the conceptual dimensions of co-creation. 
After a review of these dimensions, and taking into account the peculiarities of the postgraduate educational sector, it is precisely the living lab which best represents this process of working co-creation because it stimulates the work process in real work situations and settings. At the same time and given the peculiarity of the purchase process of a master, we consider that the commitment of the Lead Users is something that should also be considered.

In the last stage, the aim of our research is to empirically measure the impact and consequences of co-creation in the postgraduate student's satisfaction and loyalty towards the educational institution which facilitates participation in this co-creation. The proposed relations are a consequence of a literature review whose outcome is a structural equation model (SEM) where these hypothetical relations between co-creation and student satisfaction and loyalty towards the university are proven. From the analysis of the information it can be concluded that student participation in co-creation with the university leads to higher levels of satisfaction and greater loyalty.

This first quantitative study has led to a validation of the proposed model which allows us to affirm that, independent of the results obtained in the cocreation process, the student involvement in it, will result in greater satisfaction and loyalty towards the institution. For this reason co-creation can help the educational institutions to develop competitive differentiating strategies which will generate not only a greater satisfaction for the student but also the possibility of achieving differentiation thanks to the resulting innovation.

After this first quantitative study, a second study was carried out in a Business to Business context by sending a professional from the company to the educational institution. In this study an attempt was made to measure the consequences of co-creation in student satisfaction, strength of the relation and student loyalty. This new structural equation model (SEM) has more variables and relations than the former one, introducing the strength of the relation. In addition, the study is centered on adult students who in this case are professionals sent by their companies to study a master program, Business to Business as opposed to Business to Consumer from the former study.

The conclusions of the study are that the co-creation where the adult student participates in the process takes them to higher levels of satisfaction and greater loyalty towards the educational institution. At the same time, our research shows that the strength of the relation is positively influenced by the process of creation of value. In this case, the research has only validated part of the model. Therefore, this last part of our research again reaffirms the idea that co-creation can be a beneficial tool for universities in order to develop competitive strategies which generate more value for their clients and which also makes it difficult for the competition to imitate.

Finally it should be pointed out that the results of this research facilitate the implementation of a co-creation process between universities and postgraduate students as well as the possible areas of its application within the purchase process and choosing a master program. On the other hand, it has also been demonstrated that independent of the results of this process, cocreation itself leads to higher rates of satisfaction, an improvement in the strength of the relation and more student loyalty towards the institution. 


\section{Agradecimientos}

En primer lugar, quiero dar las gracias a la Directora de esta tesis, Dña Gabriela Ribes Giner cuya dedicación y firmeza han sido claves para poder llevar esta Tesis a término.

En segundo lugar a mis compañeros de la Universidad Europea por el ánimo para que siguiera en los momentos difíciles ofreciéndome su apoyo y ayuda

No puedo dejar de citar a mi madre, que desde su ejemplo me enseñó lo que significa la perseverancia y el sentido de la responsabilidad y honradez. $Y$ por supuesto, agradecer a mis dos hijos, Alejandro y Pablo, su gran apoyo y comprensión en muchos momentos. Sin ellos a mi lado, esta tesis no hubiera sido posible. 
Índice:

\section{CAPITULO 1: INTRODUCCIÓN}

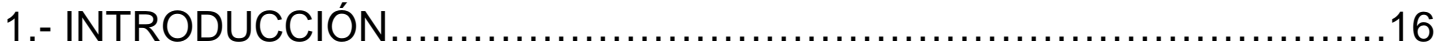

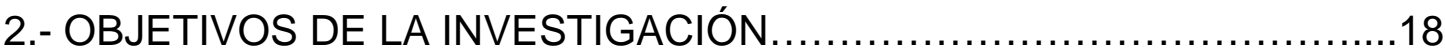

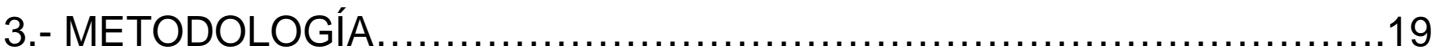

3.1 Revisión bibliográfica

3.2 Metodo Delphy

3.3 Modelo de Ecuaciones Estructurales ( SEM)

4.- DATOS DEL ESTUDIO Y SUS CARACTERÍSTICAS .....................21

5.- RESUMENES EXTENDIDOS DE LOS ARTÍCULOS .....................22

5.1. A proactive market orientation for the postgraduate programs....22

5.2. Co-creation innovation model for masters programs in the universities.

5.3. Métodos y técnicas facilitadoras de la co-creation innovation en programas de máster para el mercado del posgrado.

5.4. Co-creation between students and universities and its effects on the student's satisfaction and loyalty towards university

5.5. Value of Co-creation in the multi-stakeholder "university-companyemployee" system as a marketing strategy for educational institutions.......25

6.- BIBLIOGRAFÍA MÁS RELEVANTE ...................................26

\section{CAPÍTULO 2: A PROACTIVE MARKET ORIENTATION FOR THE POSTGRADUATE PROGRAMS}

ABSTRACT

1.- INTRODUCTION: TRENDS IN THE MARKET OF POSTGRADUATE

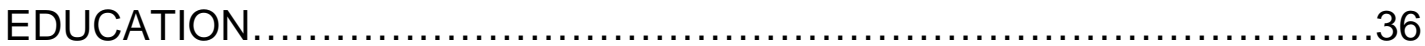

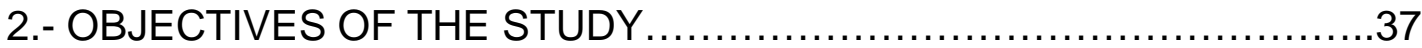

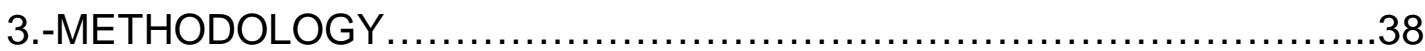

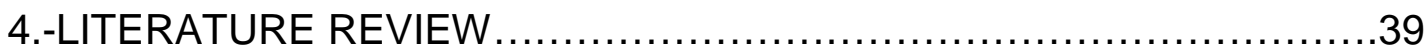

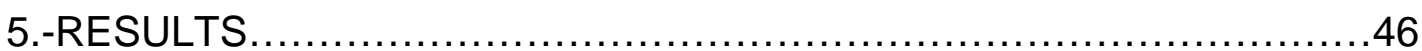

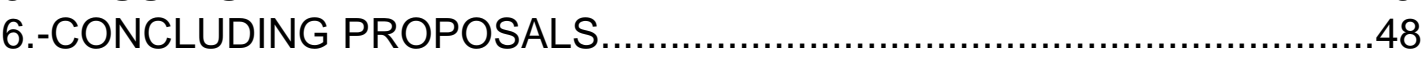

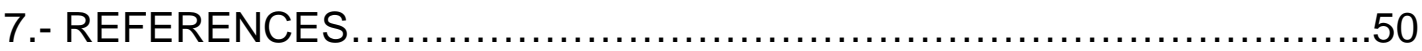

CAPÍTULO 3: CO-CREATION INNOVATION MODEL FOR MASTERS PROGRAMS IN THE UNIVERSITIES

ABSTRACT .............................................................. 56

1.-INTRODUCTION: TRENDS IN THE MARKET OF POSTGRADUATE

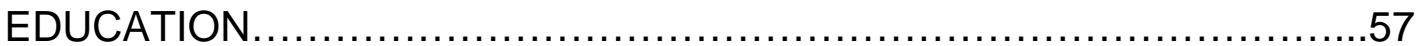

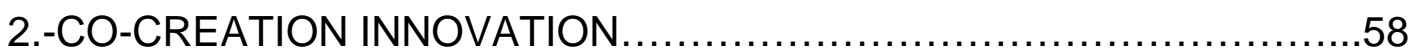

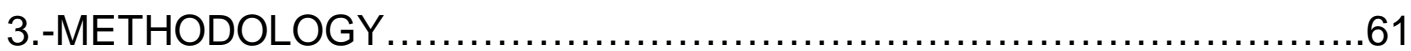

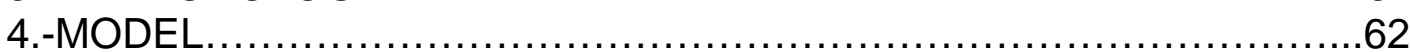

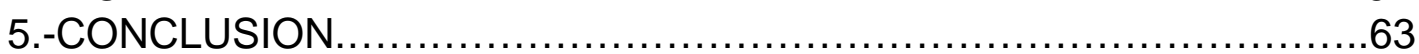

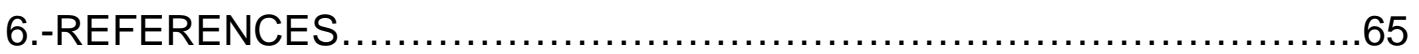


CAPÍTULO 4: METODOS Y TECNICAS FACILITADORAS DE LA COCREATION INNOVATION EN PROGRAMAS MASTERS PARA EL MERCADO DEL POSGRADO

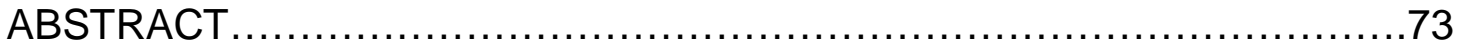

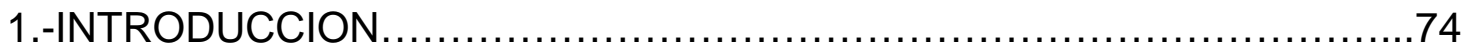

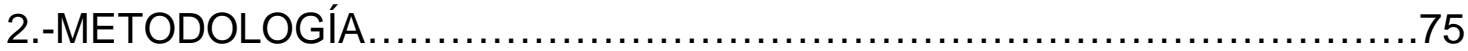

3.-REVISIÓN DE LA LITERATURA .............................................76

4.-RESULTADOS: CLASIFICACIÓN DE LAS METODOLOGÍAS Y TÉCNICAS

PARA LA CO-CREATION INNOVATION ................................... 82

5.-CONCLUSIONES Y FUTURAS LÍNEAS DE INVESTIGACIÓN.............84

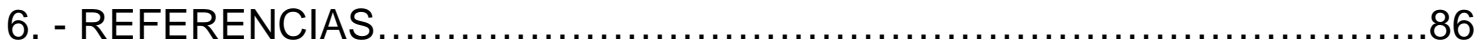

CAPÍTULO 5: CO-CREATION BETWEEN STUDENTS AND UNIVERSITIES AND ITS EFFECTS ON THE STUDENT'S SATISFACTION AND LOYALTY TOWARDS UNIVERSITY

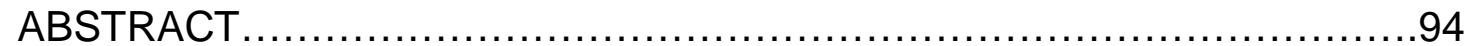

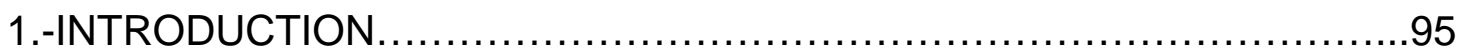

2.-BACKGROUND, HYPOTHESIS AND CONCEPTUAL MODEL ..............95

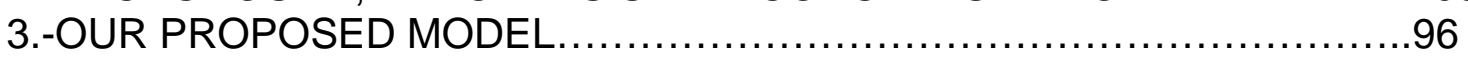

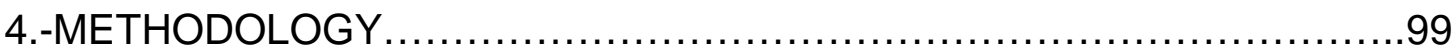

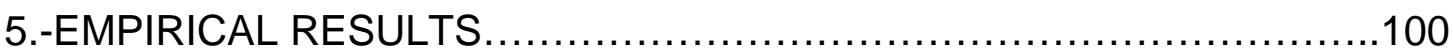

6.-CONCLUSIONES, CONTRIBUTIONS AND IMPLICATIONS ..............104

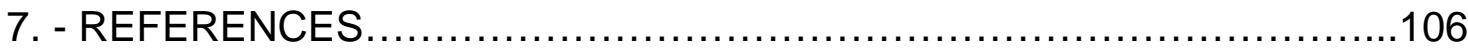

CAPITULO 6: VALUE OF CO-CREATION IN THE MULTI-STACKEHOLDER "UNIVERSITY-COMPANY-EMPLOYEE" SYSTEM AS A MARKETING STRATEGY FOR EDUCATIONAL INSTITUTIONS

1.-INTRODUCTION ......................................................... 110

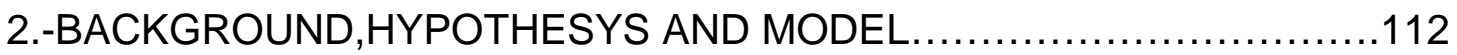

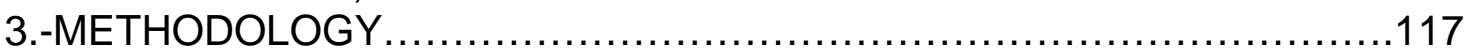

4.-EMPIRICAL RESULTS ........................................................ 117

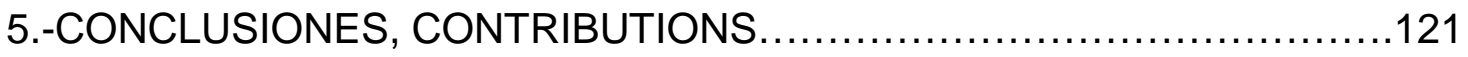

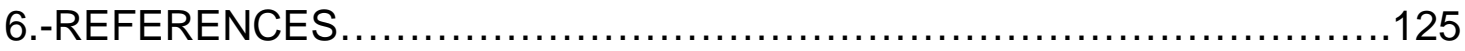

CAPÍTULO 7: CONCLUSIONES

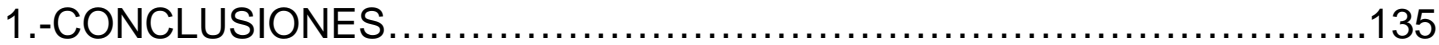

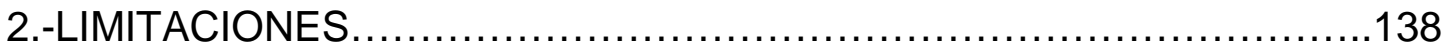

3.-FUTURAS LINEAS DE INVESTIGACIÓN.............................139

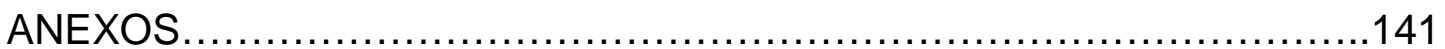


CAPÍTULO 1

INTRODUCCIÓN

13 


\section{1.- Introducción}

Desde la adaptación de la educación al Espacio Europeo de Educación Superior (Real Decreto 1509/2005), las universidades españolas ofrecen dos tipos de máster para completar los estudios de grado: Título propio o Máster oficial, reglado con parámetros de certificación. En esta tesis, el concepto de máster hace referencia al los másteres oficiales y máster título propios de la universidad relacionados con la gestión de empresas.

En la actualidad, la competencia entre las universidades actuales en lo que se refiere a sus programas de posgrado se incrementa de año en año debido a la compleja situación económica, la economía global, la introducción de programas en línea y la aparición de instituciones educativas por todo el mundo (Schimel et al., 2011; Eschenfelder, Clark, Marco y Racic, 2011). A la vez que aumentan la oferta por parte de las distintas instituciones educativas y el abanico de programas donde elegir los alumnos, impera la necesidad por parte de las universidades de mejorar su conocimiento sobre el mercado y más concretamente sobre el mercado de posgrado, debido a la falta de investigación existente (Hegarty, 2011). La literatura sobre marketing para el mercado de posgrado es incoherente y carece de modelos teóricos que tengan en cuenta la situación competitiva de este mercado (Hemsely-Brown y Oplatka, 2006; Simoes y Soares, 2010; Chia, 2011).

Chapleo (2010) afirma que hay una falta de diferenciación real por parte de las instituciones educativas en un momento complejo y competitivo como el actual. Enache (2011) sostiene que las universidades no tienen una completa orientación hacia el mercado mientras que Nicolescu (2009) considera que el campo del marketing puede aportar mucho a las universidades más allá de la promoción y la comunicación. Enache y Casatas (2011) afirman que el desarrollo y la proporción de información e instrumentos dentro del área del marketing ayudarán a las instituciones educativas a desarrollar estrategias competitivas adecuadas para lograr atraer a los estudiantes. Maringe y Gibbs (2012) consideran que las universidades deben aprender del mundo real de la empresa para desarrollar perspectivas más orientadas a sus consumidores, estudiantes y empresas.

Esto supone, por parte de las universidades, la necesidad de desarrollar una orientación proactiva hacia el mercado como inicio de esa estrategia de diferenciación (Oplataka y Hemsley-Brown, 2007). Además, esta orientación proactiva hacia el mercado, tendrá una particularidad en el caso de los programas de posgrado: no solamente tendrá que considerar al estudiante adulto de posgrado, sino también a las propias empresas, ya que en ocasiones son ellas las que apuestan por esos programas al enviar a sus propios profesionales (Kotler y Fox, 1995; Nicolescu et al., 2009). Para el posgrado, el conocimiento y dominio del proceso de decisión del estudiante adulto es precisamente una de las carencias de la literatura de investigación (Vrontis, 2007; Sánchez Herrera et al., 2009).

Esta más que necesaria orientación proactiva hacia el mercado en la búsqueda de una estrategia de diferenciación, pasará, como en muchos otros 
sectores, por apostar por políticas de marketing exitosas que permitan ofrecer a los estudiantes aquello que más se acerque a sus necesidades y que sea diferente a lo ofertado por otras instituciones, es decir, innovar (Kotler y Kelle, 2009). Son muchos los autores que relacionan claramente esa orientación proactiva hacia el mercado con la co-creation (Von Hippel, 2005; Piller et al., 2011; Dahan y Hauser, 2002).

Vargo y Lush (2004) definen el concepto de co-creation como la forma en que las empresas o instituciones se relacionan con sus clientes para crear conjuntamente más valor mediante el involucramiento y la participación de todos. Más concretamente, en relación con el sector educativo, Piller et al. (2011) describen el concepto de co-creation como la implementación de fórmulas de management enfocadas en el estudiante, que utilizan la información y las capacidades del estudiante en el proceso de innovación.

Por lo tanto, dentro de las distintas posibilidades del marketing, innovar, bajo el paradigma de la co-creation e involucrar al cliente como co-creador, aparece como una fórmula que puede ser determinante para el éxito de las mismas (Sjodin y Kristenson, 2012). De una manera más general, son varios los autores que afirman que la co-creación puede provocar efectos positivos en los resultados empresariales (Lusch y Vargo, 2006; Ballantyne y Barey, 2008).

En relación a la implementación de esta co-creation, Storback y Frow (2008) afirman que escasean los estudios donde se profundice cómo llevar a cabo este proceso de co-creation y se propongan técnicas y métodos útiles para ello. Witell et al. (2011) insisten en la importancia de identificar aquellos métodos y técnicas que faciliten el trabajo e interacción en entornos reales de mercado.

Por todo ello, en un momento de cierta complejidad como el actual en el sector educativo de posgrado, todo apunta a que debería estudiarse la cocreation y su aplicación por parte de las instituciones educativas. La co-creation se ha estudiado poco en el sector educativo y siempre desde una vertiente centrada en los estudiantes universitarios, no de posgrado, como co-creadores del servicio que reciben (Bovill, Cook-Sather y Felten, 2011). Profundizar tanto en un mejor dominio del proceso de decisión del estudiante adulto de posgrado como en las mejores técnicas para poder implementar junto a él un proceso de co-creation es algo que aportaría conocimiento útil para las instituciones educativas de posgrado.

Por último, son diversos los estudios en otros sectores que demuestran que la co-creation tiene efectos positivos en la satisfacción, relación y lealtad del consumidor con la empresa (Kotze y du Plessis, 2003; Ault et al., 2007; Hoyer et al., 2010; Rajhal et al., 2011). Hasta la fecha no existe ningún estudio realizado que mida las consecuencias de la co-creation con estudiantes adultos de posgrado.

Por tanto, esta tesis ayuda a llenar este vacío existente al centrarse tanto en las consecuencias del uso de la co-creation por parte de las universidades con estudiantes de posgrado como en el mayor conocimiento del proceso de decisión del estudiante adulto y la consecuente mejor técnica y método para implementar la co-creation con este. 


\section{2.- Objetivos de la Investigación}

En un entorno global y altamente competitivo como el actual para las instituciones educativas, la co-creation puede desempeñar un papel fundamental de diferenciación tanto a través de una innovación de más éxito como por el hecho de que el propio proceso de co-creation conlleve consecuencias sobre la fidelización y la satisfacción del consumidor, en este caso del estudiante adulto, como ha ocurrido en otros sectores.

Esta tesis tiene como objetivo general contribuir al conocimiento de la co-creation para el mercado de educación de posgrado facilitando el proceso para una adecuada implementación de la misma, dominando el proceso de decisión, las mejores técnicas y métodos para su aplicación, así como las consecuencias de su implementación en el propio estudiante adulto y en la fidelización y satisfacción del mismo. De manera más concreta, en esta tesis se han marcado los siguientes objetivos específicos:

1.- Estudiar, ante un entorno como el actual, la necesidad por parte de las universidades de desarrollar políticas de proactive market orientation (orientación proactiva hacia el mercado) como primer paso para su diferenciación.

2.- Examinar que, dentro de ésta filosofía de proactive market orientation, la co-creation innovation puede ser una herramienta muy útil para las universidades como estrategia de diferenciación, proponiendo métodos y técnicas para implementar con éxito la co-creation.

3.- Desarrollar un modelo que permita trabajar la co-creation para programas másteres donde universidad-empresa y estudiante adulto colaboran para evidenciar las distintas posibilidades que ofrecería el trabajar bajo este paradigma de la co-creation.

4.- Medir los efectos que la co-creation tendría en los marketing outputs de satisfacción y lealtad para los estudiantes que participen en este proceso de co-creation bajo la perspectiva Business to consumer (estudiante profesional que decide por sí mismo realizar el master)

5. Medir los efectos que la co-creation tendría en los marketing outputs de satisfacción, fortaleza en la relación y lealtad para los estudiantes que participen en este proceso de co-creation si bien en este caso, bajo la perspectiva Business to Business (estudiante profesional enviado por su propia empresa)

Esta tesis está estructurada en un compendio de cinco artículos.Cada artículo aparece de manera estructurada en los distintos capítulos de la tesis.

En el presente capítulo 1, se realiza la introducción a la tesis, se definen los objetivos de la investigación y la estructura de esta, y se finaliza con las metodologías utilizadas y un resumen extendido de los mismos.

En el capítulo 2, se incluye el artículo $A$ proactive market orientation for the postgraduate programs. El artículo fue publicado en el volumen 50 de la revista Dirección y Organización en julio de 2013. La citada revista está 
indexada en: Scopus, Latindex, In-reus, Dice, Dialnet, Compludoc, E-revistas, Redalyc e Isoc.

En el capítulo 3, se presenta el artículo Co-creation Innovation Model for Masters Programs in the Universities, aceptado y publicado como capítulo 13 del libro Innovation and Teaching technologies: New Directions in Research, Practice and Policy editado por la prestigiosa editorial Springer.

En el capítulo 4, se presenta el artículo Métodos y técnicas facilitadoras de la co-creation innovation en programas máster para el mercado de posgrado. Este artículo fue publicado en el volumen 10, número 1, de la revista Intangible Capital en abril de 2014. La revista está indexada de la siguiente manera:RESH: C (0.192); Carhus + (2014): C; Índice de difusión Internacional DICE: 16.5; Latindex ; MIAR 2013 - ICDS: 7.454; CIRC: B; In-Recs (2011): 0.111; Index Copernicus: ICV: 1,03 points; H Google Scholar Metrics: 7 - 9; SCImago Journal \& Country Rank (SJR 2013): 0,191; Source Normalized Impact per Paper (SNIP 2013): 0.602.

En el capítulo 5, se incluye el artículo Value of Co-creation in the multistakeholder "university-company-employee" system as a marketing strategy for educational institutions. Este trabajo fué presentado en el congreso Internacional en la UPV "Mathematical Modelling in Engineering \& Human Behaviour 2014" celebrado en septiembre 2014. El artículo posterior ha sido aceptado por la revista Journal of Computational and Applied Mathematics. La revista está indexada en el SSCI (Índice de impacto JCR-SSCI 2013: 1.077.Posición en el cuartil Q2 MATHEMATICS, APPLIED)

En el capítulo 6, se presenta el artículo Value of Co-creation in the multistakeholder "university-company-employee" system as a marketing strategy for educational institutions propuesto y en estado de revisión en el especial issue 'Theory and Practice of Value Co-Creation in B2B Systems' en Noviembre del 2014 para la revista Industrial Marketing Management. La revista está indexada en el SSCI (Índice de impacto JCR-SSCI 2013: 1.897.Posición en el cuartil Q2 MANAGEMENT).

Por último, en el capítulo 7 se presentarán las conclusiones de la tesis junto con las posibles limitaciones del estudio así como la definición de las futuras líneas de investigación derivadas.

\section{3.- Metodología}

Esta tesis ha seguido el formato de tesis por compendio de publicaciones y en ella se incluyen cinco artículos publicados en revistas académicas internacionales. Cada uno de ellos aborda las diferentes etapas de este estudio y en su conjunto, explican el contenido de la tesis. En los artículos se han utilizado distintas metodologías que se ajustaban a los propósitos de cada uno de los estudios.

A continuación se exponen las distintas metodologías utilizadas.

\subsection{Revisión bibliográfica}

El proceso de revisión de la literatura o revisión bibliográfica es un proceso clave dentro de una tesis doctoral que se utiliza para gestionar la 
diversidad de conocimientos para una investigación académica específica. Supone una recopilación sistemática de la información publicada hasta esa fecha en relación al tema de investigación. El tema y preguntas sobre la investigación planteada dirigen inicialmente a la búsqueda de referencias de artículos relacionados con el tema de investigación.

Las revisiones sistemáticas difieren de las revisiones bibliográficas tradicionales al adoptar un proceso replicable, científico y transparente; en otras palabras, una tecnología detallada que tiene como objetivo minimizar el sesgo a través de búsquedas exhaustivas de la literatura de los estudios publicados y no publicados y que proporciona una pista de auditoría de las decisiones de los revisores, procedimientos y conclusiones (Cook et al., 1998). El proceso de revisión sistemática y su procedimiento asociado, el metaanálisis, se ha desarrollado en la última década y ahora desempeña un papel importante en las prácticas basadas en la evidencia (Tranfield et al., 2003).

El objetivo final de esta revisión es poder identificar esos vacíos de investigación que conduzcan a generar nuevas investigaciones como la presente para completar y enriquecer el conocimiento sobre la temática.

\subsection{Metodo Delphy}

El método Delphi en un proceso de investigación que consiste en la selección de un grupo de expertos a los que se les pregunta su opinión sobre cuestiones referidas a la temática tratada. Las estimaciones de los expertos se realizan en sucesivas rondas, anónimas, al objeto de tratar de conseguir consenso, pero con la máxima autonomía por parte de los participantes. Este método ha demostrado ser una herramienta eficaz y válida en investigación para la identificación, priorización y validación de temas en relación a investigaciones buscando las opiniones de los panelistas (Alsmadi y Khan, 2010). Holsapple y Joshi (2000) utilizaron un método Delphi para desarrollar un modelo definitivo de una propuesta inicial basada en una revisión bibliográfica como ha sido nuestro caso. Son muchos los ejemplos donde se han utilizado paneles de Delphi para validar modelos. Mencionaremos el liderado por Zhang y Salaba (2009), donde se les pidió a los miembros del panel que plantearan cuestiones críticas acerca de su modelo FRBR para los registros bibliográficos; y el de Tracey y Richey (2007) y su modelo, que fue revisado y validado por expertos en el campo del diseño instruccional a través de un estudio Delphi de tres rondas.

\subsection{Modelo de Ecuaciones Estructurales (SEM)}

La técnica del modelo de ecuaciones estructurales o SEM (Structural Equation Modeling), también llamada «análisis de la estructura de covarianzas», es una técnica confirmatoria que trata principalmente de comprobar si un cierto modelo teórico es válido. Ejemplos de esta técnica son el análisis factorial, la regresión y el path analysis (Hair et al., 1999).

La diferencia principal entre el SEM y otras técnicas de relaciones multivariantes es el uso de relaciones distintas para cada conjunto de variables dependientes. SEM estima una serie de ecuaciones de regresión múltiples, pero interrelacionadas mediante la especificación de un modelo estructural. Así, el investigador utiliza la teoría, la experiencia previa y los objetivos de su investigación para determinar qué variables independientes predicen cada 
variable dependiente. Estas relaciones se trasladan posteriormente a una serie de ecuaciones estructurales para cada variable independiente. De este modo, se pueden descubrir relaciones causales entre las variables objeto de estudio, ya que esta técnica permite medir varias relaciones entre las variables dependientes o independientes.

En definitiva, la técnica SEM es una herramienta matemática, basada en un modelo teórico con el objetivo de describir relaciones de una serie de datos empíricos. Ello requiere que previamente, en base a la teoría, se hayan definido las variables que integran el modelo propuesto.

El estudio de estas relaciones causales trata de determinar el efecto que tiene una variable explicativa sobre la explicada, y en qué medida la variación observada de esta es debida a los cambios producidos por aquella. Así, en el SEM, tendremos por un lado variables manifiestas, medibles y observables, y variables latentes o no observables (Bou y Satorra, 2003). Las variables latentes son aquellos conceptos supuestos y no observados que sólo pueden ser aproximados mediante variables medibles y observables. Por otro lado, las variables observadas, recogidas a través de varios métodos de observación de datos, son las conocidas como variables manifiestas.

Este enfoque confirmatorio, capaz de medir varias relaciones de dependencia sin descuidar los posibles errores de medida en la estimación, es lo que ha convertido al SEM en una herramienta integral tanto en la investigación académica como en la práctica.

La principal característica del SEM es su enfoque confirmatorio. Mientras que en un enfoque exploratorio, la estructura de los factores subyacentes a la matriz de datos no es conocida o especificada a priori, en un enfoque confirmatorio, existe una teoría y una serie de hipótesis que nos sugieren un modelo de relaciones entre las variables. La pregunta que nos hacemos al aplicar la técnica del SEM es: ¿cómo se ajustan los datos al modelo propuesto? (Hair et al., 1999).

Por último es necesario señalar que un modelo de ecuaciones estructurales cuenta con dos submodelos: el submodelo de medida que contiene la forma en que cada variable latente, está medida a través de una serie de indicadores observables, los errores de medición y las relaciones que se esperan encontrar entre los constructos al relacionarse entre sí; el submodelo de relaciones estructurales, el que realmente se desea estimar y que recoge los efectos y las relaciones entre los distintos constructos.

\section{4.-Datos del estudio y sus características}

En la pimera parte del trabajo se estudia la situación actual del marketing para las instituciones educativas así como la co-creation en todo lo referente y publicado sobre ello.

Posteriormente se realiza un estudio cualitativa delphy a través de expertos

El estudio cualitativo delphy se llevó a cabo en dos fases diferenciadas. En la primera fase se testaba el modelo propuesto con un conjunto de tres preguntas abiertas para ser respondidas en formato escrito y una descripción del propósito del estudio. En segunda fase del delphy, se buscaba confirmar 
las modificaciones planteadas por los panelistas en la primera fase, en definitiva si estaban o no de acuerdo con ellas.

Los panelistas eran profesores y miembros de la administración de las universidades en relación con los programas máster así como estudiantes adultos que ya han participado en un programa de postgrado y Directores de Recursos Humanos que han enviado directivos a realizar másters en el pasado.

Junto a los métodos culitativos anteriormente citados, se utilizó una metodología cuantitativa el modelo de ecuaciones estructurales. Bajo esta metodología se realizaron dos estudios.

En el primero de ellos, que buscaba medir el impacto de la co-creation en un entorno Business to Consumer, se realizaron 196 encuestas a alumnos de posgrado que habían decidido por ellos mismos realizar el máster con independencia de la empresa donde trabajaban.

En el segundo estudio, se realizaron 200 encuentas a alumnos de posgrado que habían sido enviados por sus empresas para realizar el master. Este segundo trabajo pretendía medir el impacto de la co-creation en un entorno Business to Business.

Los datos necesarios para poder cumplir con los objetivos de la investigación y para contrastar las hipótesis $r$ se obtuvieron mediante un cuestionario en el tiempo de clase (encuestas cara a cara). La rotación de los elementos fue introducido para reducir el error de medición o método de recolección (producido por el orden en que aparecen los estímulos o las alternativas de respuesta) (sesgo del método común). En ambos casos, la muestra es de estudiantes adultos provenientes de programas masters a tiempo parcial de 2 universidades españolas. El tamaño de muestra señalado es el mínimo necesario para el correcto funcionamiento de la metodología estadística aplicada. De ellos, el $46 \%$ son mujeres y el $54 \%$, hombres. El instrumento utilizado fue una escala de Likert de 1 (totalmente en desacuerdo) a 7 (totalmente de acuerdo) para la respuesta de 21 cuestiones.

\section{5.- Resúmenes extendidos de los artículos}

\subsection{A proactive market orientation for the postgraduate programs}

La situación actual del mercado de los másteres supone que las instituciones educativas se enfrentan a una competencia cada vez mayor debido principalmente a la situación económica actual, la globalización de todos los sectores, incluido el educativo, y la introducción de programas educativos en línea. Esta situación de mercado sugiere que las universidades consideran el marketing como una herramienta necesaria para reflexionar sobre su mercado y desarrollar las estrategias adecuadas. En consecuencia, es necesario invertir recursos con el fin de tener un mayor dominio del mercado y del consumidor adulto para poder influir en el proceso de elección de los futuros estudiantes.

A través de una revisión de la literatura, este artículo pretende conocer, en un momento de alta complejidad como el mencionado, hasta qué punto las universidades tienen una orientación proactiva hacia el mercado en relación a 
sus estudios de posgrado. Por lo tanto, el principal objetivo es ayudar a las universidades para que desarrollen una «orientación proactiva hacia el mercado» como precedente para una política de innovación de éxito para sus programas de posgrado y en definitiva, una clara diferenciación en el mercado.

Para ello se realiza una revisión profunda de los conceptos de «orientación proactiva hacia el mercado» en el sector de posgrado y del «proceso de compra» de un programa de posgrado por parte del estudiante adulto. Con esta revisión bibliográfica se ha pretendido avanzar en el conocimiento planteando un primer modelo innovador que describe «el proceso de compra del estudiante adulto» con sus diferentes fases cuando se enfrente a la decisión y elección de un máster, algo no desarrollado hasta el momento.

Este «modelo de proceso de toma de decisiones» será el marco perfecto que facilitará diferentes reflexiones sobre los clientes, empresas, universidades y todas las posibles interacciones que pueden existir bajo una «orientación proactiva hacia el mercado» y las consiguientes estrategias para realizar una política de innovación de éxito.

Por lo tanto, esta investigación hace una contribución significativa al cuerpo de conocimiento en esta importante área del marketing, en concreto en la necesidad a de una orientación proactiva al mercado. Esta orientación al mercado es la fase inicial para poder llevar a cabo políticas de innovación con éxito en las instituciones educativas que redundará en el desarrollo de estrategias diferenciadoras en un mercado complejo como el actual.

\subsection{Co-creation innovation model for masters programs in the universities}

El objetivo del presente estudio es crear un modelo basado en la cocreation y en la coexistencia de los actores "universidad-empresa-estudiante adulto" que facilite la innovación para en las las universidades en sus programas másteres como estrategia de diferenciación. Este modelo se basa en el paradigma de la innovación basada en la co-creación de universidades emprendedoras. A través de una revisión exhaustiva de la literatura de los conceptos de la orientación proactiva hacia el mercado, la innovación educativa y la innovación basada en la co-creación, hemos creado un marco para la mejora de la innovación entre las instituciones para este segmento particular de los estudiantes de posgrado. Esta herramienta tiene el potencial de facilitar la interacción entre los clientes, empresas, universidades y todas las partes interesadas en el marco del paradigma de innovación basada en la cocreación. Este proceso de interacción y comunicación entre estudiantes, empresas y universidad son la clave para una filosofía de la co-creación del cliente que lleva a las innovaciones con éxito.

Este estudio realiza una contribución significativa al cuerpo de conocimientos de las las universidades para el desarrollo de estrategias diferenciadoras con el tema concreto de la innovación y las estrategias competitivas. En concreto, este estudio Estudios de este tipo, pueden ayudar a los profesores universitarios, administradores y gerentes de las instituciones educativas en la adaptación de sus estrategias de marketing, entre ellas su política de innovación basada en la co-creation. Las consecuencias de esta cocreation serán estudiadas con detalle tanto en su influencia en el estudiante qué participa como en los resultados en las innovaciones de la misma con el 
fin de diferenciarse de la competencia en un sector tan complejo como el de educación de posgrado.

5.3. Métodos y técnicas facilitadoras de la co-creation innovation en programas de máster para el mercado del posgrado

La innovación en los programas de máster, como estrategia de diferenciación para las instituciones educativas, es crucial en un momento complejo como el descrito en el mercado educativo de posgrado. La cocreation como método de innovación está siendo considerada en diversos mercados como una estrategia que mejora la tasa de éxito en innovaciones de servicios, lo que conlleva efectos positivos en los resultados empresariales. Son muy pocos los estudios realizados hasta la fecha sobre co-creation para las instituciones educativas y prácticamente inexistentes aquellos que se centran en el mercado de posgrado.

El objetivo del presente estudio es proponer métodos y técnicas para implementar con éxito en las universidades un proyecto de innovación basado en el paradigma de la co-creation innovation para el mercado de los programas de máster. Con ello, se pretende facilitar a las universidades el camino hacia una política de innovación con éxito en su oferta formativa de los programas de máster, entendida como un binomio producto-servicio. Este proceso de innovación basada en la co-creación requiere una colaboración activa entre las distintas partes involucradas en este proceso: el estudiante adulto de posgrado, las empresas empleadoras y el personal de la universidad, que es la proveedora del servicio de formación. A través de una revisión de la literatura sobre las mejores prácticas de co-creation innovation en otros sectores, se han identificado los diferentes métodos y técnicas utilizados con buenos resultados. Además, se ha realizado una clasificación de los mismos, en función de las dimensiones conceptuales de la co-creation innovation. De esta manera, este estudio supone un avance más en la aplicación del modelo propuesto por Ribes y Peralt (2013) para potenciar la innovación, basado en el paradigma de la co-creation innovation como posible estrategia de diferenciación para las universidades en el mercado del posgrado.

De la clasificación planteada de los métodos señalados es precisamente el living lab el que mejor representa ese proceso de trabajar la co-creación en situaciones y entornos reales de trabajo. Al mismo tiempo, dada la particularidad del proceso de compra de un máster, consideramos que el involucramiento de Lead Users es algo que también se debe considerar.

Esta investigación supone una invitación y propuesta para las instituciones educativas para que planteen dinámicas de este tipo que pueden suponer una vía para disponer de una estrategia diferenciadora al aumentar la probabilidad de éxito de sus políticas innovadoras adaptadas a sus estudiantes adultos.

5.4. Co-creation between students and universities and its effects on the student's satisfaction and loyalty towards university

Este artículo tiene como objetivo medir el impacto y las consecuencias de la co-creación en la satisfacción y en la lealtad del estudiante de posgrado con la universidad a la que asiste, algo de suma importancia en un momento 
como el actual de alta competencia entre las universidades en sus programas de posgrado. Esta lealtad hacia la institución educativa resulta de suma importancia por la necesidad actual de desarrollar estrategias competitivas diferenciadoras. En este caso, supondrían incrementar la probabilidad de fidelización hacia la institución con los programas de posgrado posteriores a la finalización de los estudios universitarios con las recientes modificaciones del tratado de Bolonia.

El objetivo de nuestra investigación es comprobar de una manera empírica hasta qué punto la co-creation contribuye a la satisfacción, y la lealtad entre los alumnos universitarios que participan en ese proceso de co-creation junto con las instituciones educativas. Las relaciones propuestas son consecuencia de una revisión de la literatura cuya consecuencia en un modelo de ecuaciones estructurales (SEM) donde se comprueban esas relaciones hipotéticas entre la co-creación y la satisfacción y la lealtad por parte del estudiante hacia la universidad.

Del análisis de la información se puede concluir que la participación del alumno en la co-creation con la universidad lleva a niveles mayores de satisfacción, y a una mayor lealtad.

Este estudio ha supuesto una validación del modelo propuesto, por lo que podemos afirmar que todos los esfuerzos de las instituciones educativas por una mayor implicación del alumno como co-creador del servicio redundarán en una mayor satisfacción y lealtad de este hacia la institución. Por todo ello, la co-creación puede facilitar el que las instituciones educativas desarrollen estrategias competitivas diferenciadoras que generarán mayor valor para los estudiantes y el que logren la diferenciación necesaria en el momento actual de gran competencia en el mercado de la educación superior.

5.5. Value of Co-creation in the multi-stakeholder "university-companyemployee" system as a marketing strategy for educational institutions

El artículo pretende medir el valor y consecuencias que tiene la cocreación para el consumidor como consecuencia de su participación en un proceso de co-creation en un contexto de Business to Business (BtB) de estudiantes adultos enviados por sus empresas a realizar programas de máster. El estudio es en sí innovador por considerar las consecuencias de la co-creation en un sistema de interacción «universidad-empresa-empleado» con distintas partes interesadas, donde la empresa envía a sus empleados a inscribirse en un programa de máster a tiempo parcial en una institución educativa.

El objetivo del estudio es medir empíricamente el impacto del valor de la co-creación en la satisfacción, la fortaleza de la relación creada y la lealtad por parte del estudiante de posgrado, hacia la institución educativa.

A partir de un modelo de investigación conceptual con algunas relaciones hipotéticas basadas en una revisión de la literatura en profundidad, se utiliza un modelo de ecuaciones estructurales (SEM) para analizar esas relaciones hipotéticas entre la co-creación y la satisfacción, la fortaleza en la relación y la lealtad por parte del estudiante hacia la universidad en un contexto de servicio BtB. 
Las conclusiones del estudio son que la co-creación donde el estudiante adulto participa en un proceso de co-creación con la universidad, lleva a los niveles más altos de satisfacción y una mayor lealtad hacia la institución educativa. Al mismo tiempo, nuestra investigación cuantitativa también muestra que la fortaleza en la relación está influenciada positivamente para este proceso de creación de valor, si bien no media entre la co-creación y la lealtad. Consecuentemente, el estudio ha validado parte del modelo SEM propuesto.

Por tanto, se puede afirmar que todos los esfuerzos de las instituciones educativas para que los estudiantes participen como co-creadores del servicio se traducirán en una mayor satisfacción con la institución y lealtad hacia ella. Las consecuencias potenciales de la lealtad del cliente hacia las universidades son posibles incrementos de los ingresos, la reducción de los costos de adquisición de clientes, y reducción de determinadas partidas de costes lo que redundará en una mayor rentabilidad según lo declarado por Reichheld (1993) en sus investigaciones sobre las consecuencias de la fidelidad.

Así, nuestra investigación demuestra que la co-creación puede ser una herramienta beneficiosa que puede ayudar a las universidades a desarrollar una estrategia competitiva que genere más valor para sus clientes y que también sea difícil de imitar por la competencia, como señala Cova (2011) sobre el desarrollo de estrategias de diferenciación basadas en este tipo de modelos.

\section{Bibliografía más relevante}

Almirall E, Wareham J (2008) Living labs and open innovation: Roles and applicability. The Electronic Journal for Virtual Organizations and Networks; 10(3):21-46.

Auh S, Bell SJ, McLeod CS, Shih E. (2007) Co-production and customer loyalty in financial services. J Retail; 83(3):359-370.

Ballantyne D, Varey RJ (2008).The service-dominant logic and the future of marketing. Journal of the Academy of Marketing Science. ;36(1):11-14.

Basole, R. C., \& Rouse, W. B. (2008). Complexity of service value networks: conceptualization and empirical investigation. IBM systems journal, 47(1), 5370.

Battarbee, K., \& Koskinen, I. (2005). Co-experience: user experience as interaction. CoDesign, 1(1), 5-18.

Bergvall-Kåreborn B, Ihlström Eriksson C, Ståhlbröst A, Svensson J (2009) A milieu for innovation-defining living labs.

Binsardi A, Ekwulugo F. (2003) International marketing of british education: Research on the students' perception and the UK market penetration. Marketing Intelligence \& Planning.; 21(5):318-327.

Bovill, C., Cook-Sather, A., \& Felten, P. (2011). Students as co-creators of teaching approaches, course design, and curricula: implications for academic developers. International Journal for Academic Development, 16(2), 133-145. 
Bowden JL, D'Alessandro S. (2011) Co-creating value in higher education: The role of interactive classroom response technologies. Asian social science; 7(11):p35.

Bowonder B, Dambal A, Kumar S, Shirodkar A (2010). Innovation strategies for creating competitive advantage. Research-technology management. ; 53(3):1932

Caceres, R. C., \& Paparoidamis, N. G. (2007). Service quality, relationship satisfaction, trust, commitment and business-to-business loyalty. European Journal of Marketing, 41(7/8), 836-867.

Carvalho SW, de Oliveira Mota M. (2010). The role of trust in creating value and student loyalty in relational exchanges between higher education institutions and their students. Journal of Marketing for Higher Education; 20(1):145-165.

Chesbrough HW. (2003). Open innovation: The new imperative for creating and profiting from technology. Harvard Business Press.

Chesbrough, H., Vanhaverbeke, W., \& West, J. (2006). Open innovation: a new paradigm for understanding industrial innovation. Open innovation: researching a new paradigm, 1-12.

Clark BR. Creating entrepreneurial universities: Organizational pathways of transformation (1998) issues in higher education. ERIC;

Cova B, Dalli D, Zwick D. (2011).Critical perspectives on consumers' role as 'producers': Broadening the debate on value co-creation in marketing processes. Marketing Theory;11(3):231-241.

Cronbach LJ. (1951).Coefficient alpha and the internal structure of tests. Psychometrika;16(3):297-334.

Diener K, Piller F. (2010). The market for open innovation First study to compare the offerings, methods, and competences of intermediaries, consultancies, and brokers for open innovation. RWTH-TIM Group.

Dong B, Evans KR, Zou S. (2008).The effects of customer participation in cocreated service recovery. Journal of the Academy of Marketing Science;36(1):123-137.

Edmonds, A. (2008). Customer loyalty through co-creation in an independent retail setting. Otago Marketing Review, 1, 1-4.

Enache I (2011). Marketing higher education using the 7 ps framework. Bulletin of the Transilvania University of Braşov• Vol. ;4(53).

Eriksson M, Niitamo V, Kulkki S, Hribernik KA (2006). Living labs as a multicontextual R\&D methodology. :26-28.

Eriksson M, Niitamo V, Kulkki S (2005). State-of-the-art in utilizing living labs approach to user-centric ICT innovation-a european approach. Lulea: Center for Distance-spanning Technology. Lulea University of Technology Sweden. 
Folstad A. A (2013). Guide to online applications for user involvement in living lab innovation. Information Systems and Technology for Organizations in a Networked Society:34.

Fornell C, Larcker DF. (1981).Evaluating structural equation models with unobservable variables and measurement error. J Market Res:39-50.

Foss, N. J., Laursen, K., \& Pedersen, T. (2011). Linking customer interaction and innovation: The mediating role of new organizational practices. Organization Science, 22(4), 980-999.

Fredberg T, Elmquist M, Ollila S (2008). Managing open Innovation. Present findings and future directions. . 2008.

Gajić J. (2012) Importance of marketing mix in higher education institutions. Singidunum Journal of Applied Sciences.;9(1):29-41.

Gallarza MG, Fayos T, Servera D, Arteaga F, Francés DS (2008). Análisis y evaluación del servicio de formación universitaria: Implicaciones para el marketing estratégico de las universidades.

Geyskens, I., Steenkamp, J. B. E., \& Kumar, N. (1999). A meta-analysis of satisfaction in marketing channel relationships. Journal of marketing Research, 223-238.

Giner GR, Peralt A. (2014).Métodos y técnicas facilitadoras de la co-creation innovation en programas máster para el mercado del postgrado. Intangible Capital;10(1).

GMAC Survey (2010).Graduate Management Admission Council

Greer CR, Lei D (2012). Collaborative innovation with customers: A review of the literature and suggestions for future research. International Journal of Management Reviews;14(1):63-84.

Grissemann US, Stokburger-Sauer NE.(2012) Customer co-creation of travel services: The role of company support and customer satisfaction with the cocreation performance. Tourism Management;33(6):1483-1492.

Gruner KE, Homburg C (2000). Does customer interaction enhance new

product success? Journal of business research. ;49(1):1-14.

Guldemond, N., \& van Geenhuizen, M. (2012). 'Livings Labs' for New Health Concepts and Medical Technology in Cluster Development.

Gustafsson E, Jonsson A (2003). Always best connected. Wireless Communications, IEEE;10(1):49-55.

Gustafsson A, Kristensson P, Witell L. (2012).Customer co-creation in service innovation: a matter of communication Journal of Service Management;23(3):311-327.

Jaakkola, E., \& Hakanen, T. (2013). Value co-creation in solution networks.Industrial Marketing Management, 42(1), 47-58. 
Haas, A., Snehota, I., \& Corsaro, D. (2012). Creating value in business relationships: The role of sales. Industrial Marketing Management, 41(1), 94105.

Hair J, Black W, Babin B, Anderson R. (2010).Multivariate data analysis. 7th ed2010..

Hasche, N. (2006). Developing collaborative customer-supplier relationships through value co-creation.

Hegarty N. (2011)Who we are and whom we teach: Understanding graduate student motivation. Journal of Human Resource Education.;5(4).

Heiens RA (2000) Market orientation: Toward an integrated framework. Academy of Marketing Science Review. ;1(1):1-4.

Helgesen $\varnothing$ (2008). Marketing for higher education: A relationship marketing approach. Journal of Marketing for Higher Education;18(1):50-78.

Hemsley-Brown J, Oplatka I. (2006). Universities in a competitive global marketplace: A systematic review of the literature on higher education marketing International Journal of Public Sector Management.;19(4):316-338.

Hoyer WD, Chandy R, Dorotic M, Krafft M, Singh SS. (2010).Consumer cocreation in new product development. Journal of Service Research;13(3):283296.

Howe J (2006). The rise of crowdsourcing. Wired magazine. ;14(6):1-4. 1

Jaworski B, Kohli AK (2006). Co-creating the voice of the customer. The Service-dominant Logic of Marketing: Dialog, debate, and directions:109-117.

Kensing, F., \& Blomberg, J. (1998). Participatory design: Issues and concerns. Computer Supported Cooperative Work (CSCW), 7(3-4), 167-185.

Kohler T, Matzler K, Füller J (2009). Avatar-based innovation: Using virtual worlds for real-world innovation. Technovation; 29(6):395-407.

Kotler, P., \& Fox, K. F. (1995). Strategic marketing for educational institutions.

Kotler, P. (2001). Marketing Management Pearson Education.

Kotze TG, Du Plessis P.(2003) Students as "co-producers" of education: a proposed model of student socialisation and participation at tertiary institutions. Quality Assurance in Education;11(4):186-201.

Kristensson, P., Matthing, J., \& Johansson, N. (2008). Key strategies for the successful involvement of customers in the co-creation of new technologybased services. International Journal of Service Industry Management, 19(4), 474-491.

Lam, S. Y., Shankar, V., Erramilli, M. K., \& Murthy, B. (2004). Customer value, satisfaction, loyalty, and switching costs: an illustration from a business-tobusiness service context. Journal of the Academy of Marketing Science, 32(3), 293-311. 
Lee SM, Olson DL, Trimi S. (2012).Co-innovation: convergenomics, collaboration, and co-creation for organizational values. Management Decision;50(5):817-831.

Leonard D, Rayport JF (2003). Spark innovation through empathic design. Harv Bus Rev. 199755. Lincoln YS. Constructivist knowing, participatory ethics and responsive evaluation: A model for the 21st century. Springer.

Löh, H. (2008). How to drive innovation in CWE-A Living Lab Approach.

Lusch RF, Vargo SL (2006) Service-dominant logic: Reactions, reflections and refinements. Marketing theory ;6(3):281-288

Mai, L. W., \& Ness, M. R. (2006). A structural equation model of customer satisfaction and future purchase of mail-order speciality food. International Journal of Business Science and Applied Management, 1(1), 1-13.

Maringe F. (2006)University and course choice: Implications for positioning, recruitment and marketing. International Journal of Educational Management.;20(6):466-479.

Maringe F, Gibbs P. Marketing higher education: Theory and practice (2009).. Open University Press;

Mavondo FT, Tsarenko Y, Gabbott M. (2004).International and local student satisfaction: resources and capabilities perspective. Journal of Marketing for Higher Education;14(1):41-60.

Mintzberg, H., \& Gosling, J. (2002). Educating managers beyond borders.Academy of Management Learning \& Education, 1(1), 64-76.

Moeller S (2008). Customer integration-A key to an implementation perspective of service provision. Journal of Service Research;11(2):197-210.

Moore D, Bowden-Everson JL. (2012).An Appealing Connection-The Role of Relationship Marketing in the Attraction and Retention of Students in an Australian Tertiary Context. Asian Social Science;8(14):p65.

Mouwen K. (2000)Strategy, structure and culture of the hybrid university: Towards the university of the 21st century. Tertiary Education \& Management.;6(1):47-56.

Mulder I, Stappers PJ (2009). Co-creating in practice: Results and challenges. .

Nam K, Lee NH (2010). Typology of service innovation from service-dominant logic perspective. Journal of Universal Computer Science;16(13):1761-1775.

$\mathrm{Ng}$, I. C., \& Forbes, J. (2009). Education as service: the understanding of university experience through the service logic. Journal of Marketing for Higher Education, 19(1), 38-64.

Nicholls, J., Harris, J., Morgan, E., Clarke, K., \& Sims, D. (1995). Marketing higher education: the MBA experience. International Journal of Educational Management, 9(2), 31-38. 
Nicolescu, L. (2009). Applying marketing to higher education: Scope and limits. Management \& Marketing, 4(2), 35-44.

Niitamo V, Kulkki S, Eriksson M, Hribernik KA (2006). State-of-the-art and good practice in the field of living labs:26-28.

Nkamnebe A, Azikiw N. (2009)Towards market-oriented entrepreneurial university management for nigerian universities. The international journal of management education.;7(2):9-19.

Oliveira P, von Hippel E (2011). Users as service innovators: The case of banking services. Research Policy;40(6):806-818.

Payne, A. F., Storbacka, K., \& Frow, P. (2008). Managing the co-creation of value. Journal of the Academy of Marketing Science, 36(1), 83-96.

Peralt, A., \& Ribes, G. (2013). A proactive market orientation for the postgraduate programs. Dirección y Organización, (50), 37-47.

Piller, F. (2010). Open innovation with customers: crowdsourcing and cocreation at Threadless. Available at SSRN 1688018.

Piller F, Ihl C, Vossen A (2011). Customer co-creation: Open innovation with customers. Wittke, V. /Hanekop, H:31-63.

Pinegar, J. S. (2000). Customer Involvement in Industrial Product Development: Creating Superior Products.

Prahalad CK, Ramaswamy V (2004). Co-creating unique value with customers. Strategy \& Leadership;32(3):4-9.

Pušina $A$, Bašić $H$, Peštek $A$. Active learning methods in the context of higher education reform. (2008) Zbornik radova Ekonomskog fakulteta u Sarajevu. (28):132.

Rajah E, Marshall R, Nam I. (2008).Relationship glue: customers and marketers co-creating a purchase experience. Advances in Consumer Research;35:367373.

Ramaswamy, V., \& Gouillart, F. J. (2010). The power of co-creation: Build it with them to boost growth, productivity, and profits. SimonandSchuster. com.

Ramaswamy, V. (2009). Leading the transformation to co-creation of value.Strategy \& Leadership, 37(2), 32-37.

Sander P, Stevenson K, King M, Coates D. (2000)University students' expectations of teaching..Studies in Higher Education.;25(3):309-323.

Schimmel, K., Eschenfelder, M., Clark, J., Marco, G., \& Racic, S. (2011). Differences in selection criteria among traditional students, adult continuing education students and graduate students. American Journal of Business Education (AJBE), 2(5).

Schoenfeld G, Bruce G . (2005) .School brand images and school choices in MBA programs. GMAC Research Reports. 
Sheth, J. N., Sisodia, R. S., \& Sharma, A. (2000). The antecedents and consequences of customer-centric marketing. Journal of the Academy of Marketing Science, 28(1), 55-66.

Simões C, Soares AM. (2010)Applying to higher education: Information sources and choice factors. ;Studies in Higher Education. 35(4):371-389.

Sjödin, C., \& Kristensson, P. (2012). Customers' experiences of co-creation during service innovation. International Journal of Quality and Service Sciences, 4(2), 189-204.

Taylor RE, Reed RR. (1995)Situational marketing: Application for higher education institutions..Journal of Marketing for HIGHER EDUCATION.;6(1):2336.

Temple, P. (2009). From space to place: University performance and its built environment. Higher Education Policy, 22(2), 209-223.

Ulaga, W. (2011). Investigating customer value in global business markets: Commentary essay. Journal of Business Research, 64(8), 928-930.

Vargo, S. L., \& Lusch, R. F. (2008). Service-dominant logic: continuing the evolution. Journal of the Academy of marketing Science, 36(1), 1-10.

Vaisnore, A., \& Petraite, M. (2012). The enablement of customer's participation in the open innovation processes: an analytical framework. Economics and Management .17(4), 1600-1612.

Vanhaverbeke, W., Van de Vrande, V., \& Cloodt, M. (2008). Connecting absorptive capacity and open innovation. Available at SSRN 1091265.

Vargo SL, Lusch RF (2008). Service-dominant logic: Continuing the evolution. Journal of the Academy of Marketing Science;36(1):1-10.

Veloutsou, C., Lewis, J. W., \& Paton, R. A. (2004). University selection: information requirements and importance. International Journal of Educational Management, 18(3), 160-171.

Venkatesh U. (2001) The importance of managing points-of-marketing in marketing higher education programmes-some conclusions. Journal of Services Research.;1(1).

Verhoef, P. C. (2003). Understanding the effect of customer relationship management efforts on customer retention and customer share development.Journal of marketing, 67(4), 30-45.

Voorhees RA. (2005);Institutional research and new program development. New Directions for Institutional Research. (128):29-39.

Witell L, Kristensson P, Gustafsson A, Löfgren M. Idea generation: Customer co-creation versus traditional market research techniques. Journal of Service Management. 2011;22(2):140-159. 
Yi, Y., \& Gong, T. (2013). Customer value co-creation behavior: Scale development and validation. Journal of Business Research, 66(9), 1279-1284.

Zhang J, Zhang Z.(2008)-On degree structure of american postgraduate education for professional degree and its enlightenment [J]. Journal of Higher Education.;7:025. 
CAPITULO 2

A PROACTIVE MARKET ORIENTATION FOR THE POSTGRADUATE MARKET 


\title{
A proactive market orientation for the postgraduate market
}

Gabriela Ribes Giner. Universitat Politècnica de Valencia. Valencia, España Agustín Peralt Rillo. Universidad Europea de Valencia. Valencia, España.

\begin{abstract}
The present study aims to help universities to develop a proactive market orientation as the precedent for a successful innovation policy for their postgraduate programs through a deep review of the concepts of 'proactive market orientation' of the postgraduate market and its relative 'postgraduate decision-making process'.

This 'decision-making process model' will be the perfect framework which will facilitate different reflections about customers, companies, universities and all the possible interactions which can exist under a 'proactive market orientation' and the consequent strategies for a successful innovation policy.

Therefore, this research makes a significant contribution to the body of knowledge in this important area of market orientation as a precedent for innovation for educational institutions This proactive market research philosophy can assist the University, administrators, managers and recruiters in adapting their marketing strategies and their related innovation policy in order to differentiate from the competition in a complex sector like the postgraduate education one.
\end{abstract}

Keywords: decision-making process, master, universities, market orientation, marketing. 


\section{1. -Introduction: Trends in the market of postgraduate education}

In this paper, the 'decision-making process for postgraduate education' will refer to the process by which an adult makes the determination to enroll in a part-time postgraduate program, a part-time master.

In this introductory section, we are going to review the present situation of the postgraduate market.

The postgraduate education institutions are facing an increasingly complex competition due to today's tough economic situation, the global economy and the introduction of online education programs and institutions all around the world (Schimel et al 2009). This increasing competition among postgraduate providers is now driving the need for an improved more thorough understanding of the students 'decision-making behaviors' (Jarvis, 2000; Riana et al 2006). Indeed, as mentioned before, in Europe, the Bologna agreement has increased the complexity which sets up a correspondence between educational systems and higher levels of mobility (Pusina et Al 2008). All these numerous pressures and changes in postgraduate environment impact on a university's endeavors to attract quality students (Mouwen 2000; Ginsburg et Al 2003; Moller 2006). In this postgraduate context, strategically, one of the most important objectives of any university is attracting and retaining students suited to the courses offered (Veloutsou et al 2004). The university's marketing management has to dominate the choice decision process and to develop the right strategies according to that previous research in order to get both the students decision to enroll their program and their satisfaction with it when the service is received (Kotler, 2006). One of the challenges faced by postgraduatea institutions is catering to the needs of a growing segment of more mature students from nontraditional backgrounds, international students, and students who enroll to achieve very specific objectives( Mavondo et al 2004, Veloutsou et al 2004, Lundberg 2003).

On the other hand, considering the demand, consumers (both companies 'and their professionals' evolutional educational needs), there has been an increasing demand in the last decade of postgraduate programs (GMAC 2010). It is widely spread the idea that professionals are going to work more years than they did before, and probably in many different jobs than the one they do today (Bradshaw ,2007). Recent researches state that the postgraduate degree provides access to career advancement and the upper levels of management (Zhang and Cooper 2005). All these factors increase the need for professionals and their companies to consider a part time postgraduate program in which employees will attend while working in their present jobs. Individual benefits often include higher lifetime wages, reduced levels of unemployment and an increase in their quality of life (Bauiem et al 2010). This need is not only considered by the professionals but by the employers, not only for developing the talent inside their company but as a way of motivating them Some companies reimburse and sponsor the programs as an employee benefit. ( Kotler and Fox 1995). 
All these influences in the need for universities consider marketing as a necessary tool to reflect on their market and develop the right strategies. Consequently, it is necessary to invest time and money in order to better understand and influence the choice process among prospective students (Maringe 2006; Briggs and Wilson, 2007). Considering that the marketing of specific graduate schools has been an area assisted with a minimal amount of empirical research and the fact that the research has been focused on undergraduate students when choosing their college, it is necessary for these institutions get a deeper understanding of the decision making process among professionals for postgraduate education programs.( Claudia Simoes and Ana María Soares 2010) in order to create the appropriate marketing strategy. As Hemsley-Brown and Oplatka (2006) state there is still much to be done in the context of postgraduate markets for those with a passion for research, and a belief in the power of markets and marketing. In a special report about postgraduate studies ( Hegarty, 2011), it is stated that there is an absence of research pertaining to not only graduate students in part time programs but moreover the presence of adult learners in these programs. This knowledge and information about their potential clients will let the educational institutions understand the different segments and to target the chosen ones with the right proposition strategy and its corresponding marketing mix policies. (Kotler and Keller 2007). The more the school's marketing program is based on the results of empirical research into customer needs, the more likely it is to succeed. ( Bruce, 2009). Educational institutions need to be aware and better understand the selection process of potential students and the factors that students consider influential in making their selection. (Chia, 2011). Considering Hemsely-Brown and Oplatka's (2006) review of postgraduate marketing, the literature on postgraduate marketing is incoherent and lacks theoretical models that reflect upon the particular context of Higher Education (HE) and the nature of their service.

\section{2. -Objectives of the study}

This paper has various objectives:

1. To review all the existing literature related to both "proactive market orientation" and "postgraduate decision making process" in the postgraduate market as the first necessary step for a differentiation strategy for these educational institutions.

2. To remark the importance for postgraduate institutions for managing themselves under a "proactive market orientation" as the way to develop a successful innovation policy in order to get the needed differentiation.

3. To propose a model which explains the decision making process for the adult student in the postgraduate market as the first step for this 'proactive market orientation'.

It is obvious that a model able to provide a definition of this adult student will help any postgraduate institution to search for differentiation among the competition. Our proposed conceptual framework does not need to be the 'definitive' model but a model to be discussed with some experts to improve it. 
Also, in the future this model will be a useful framework in order to facilitate future research proposals and reflections in order to have a successful innovation policy according to the needed proactive market orientation.

\section{3. - Methodology}

To achieve the objectives laid out in this paper, we have focused the research on a systematic exhaustive review of the existing literature .The primary purpose of the literature review is to frame the research problem, identify relevant concepts and facts and fill the "gap" in existing knowledge.

All this systematic review is based on its associated procedure, meta-analysis. In management research, the literature review process is a key tool, used to manage the diversity of knowledge for a specific academic inquiry. We consider that this methodology is the right one considering the statement that systematic review helps develop a reliable knowledge base by accumulating knowledge from a range of studies ( Tranfield et Al, 2003). Systematic reviews differ from traditional narrative reviews by adopting a replicable, scientific and transparent process, in other words a detailed technology, that aims to minimize bias through exhaustive literature searches of published and unpublished studies and by providing an audit trail of the reviewers' decisions, procedures and conclusions (Cook et Al 1998). The process of systematic review and its associated procedure, meta-analysis, has been developed over the last decade and now plays a major role in evidence-based practices. ( Tranfield et Al, 2003) In our case we want to develop a framework and a model which will help innovation in the educational sector.

In our study a wide range of literature sources has been used: journals, scientific articles and books. The approach for this study entailed extensive searches of relevant business management and education databases, namely : ABI/INFORM, Emerald, ERIC, INGESTA... The main journals which have been consulted are: Studies in Higher Education, British Educational Research Journal, Handbook of service science, Research-technology management, Journal of Service Research, Review of Educational Research, Management \& Marketing, The Service Industries Journal, Academy of Management Review, International Journal of Educational Management, Research in Higher Education, Journal of the Academy of Marketing Science, European management journal, Journal of Higher Education Policy and Management, International Journal of Educational Management, Journal of Business Research, Marketing Science, Journal of International Marketing, Journal of Marketing for Higher Education, Strategy \& Leadership, American Educational Research Journal, MIT Sloan Management Review and International Journal of Services Technology and Management

Our systematic search begins with the identification of keywords and search terms, which are built from the study, the literature and discussions within the review team. We divided our search work in two different categories. 
In the first part of the review, "decision-making process for postgraduate programs", we need to identify thesaurus terms and combine them with "decision making process" and "postgraduate" These terms were: student choice , selection, postgraduate, graduate education, model, masters, adult, student, professional, university, business school, consumer behavior .

In the second part of the information review, the terms searched for a systematic review were "proactive market orientation" combined with postgraduate, higher education, masters, and university.

Lastly, and with the objective of defining these concepts considering the different authors who have defined them, we searched the concepts related to "innovation": service innovation, postgraduate innovation and co-creation innovation.

Also we tracked the searches using a database. For the citations for the references we used RefWorks 2.0 program.

\section{4-Literature Review}

\subsection{A 'proactive market orientation' for educational institutions}

On the one hand, Shattock ( 2007) noted that most universities are actually doing ( or they say they are) very like most other universities. Chapleo ( 2010) states that there is a lack of real differentiation in the educational sector in general. He considers that in spite of the similarity of products in postgraduate, there are suggested key factors to be pursued by universities to occupy positions of distinctiveness. In addition, Enache and Casatas ( 2011) states that a framework able to provide relevant information and suitable instruments will improve the market presence of any postgraduate institution. Hemsley-Brown and Oplatka (2006) consider that despite the existence of substantial literature on marketization of postgraduate and consumer behavior, the literature is incoherent and lacks theoretical models to reflect upon the particular context of postgraduate and the nature of its services. In addition, Nicolescu ( 2009) states that the marketing field is still to be developed and adapted for the postgraduate sector and apart from the promotion and communication, there are many other actions for satisfying the student which has to be considered. Besides, Enache (2011) affirms that the universities are not fully market oriented.

On the other hand, Koholi and Jaworski (1993), describe the 'market orientation' as the ability of an organization to generate, disseminate, and use superior information about both customers and competitors. Also Day ( 1994) defines this 'market orientation' concept as a pervasive commitment to a set of processes, beliefs, and values reflecting the philosophy that all decisions start with the customer and are guided by a deep and shared understanding of customers' needs and behavior for the purpose of realizing a superior performance by satisfying customers better than competitors.. Heiens (2000) states about 'market orientation' that firms should seek to understand both customers and competitors and to incorporate such knowledge in their strategic planning efforts. 
Many researches have considered the beneficial effects of being market oriented The knowledge about customers and competitors that is derived from being 'market oriented' should lead to more effectively market targeting, product development and positioning ( Hunt and Morgan,1995; Atuahene-Gima and Ko, 2001). Narver et Al (2004) considers that market orientation consists of two essential behaviors: a 'responsive market orientation' in which companies attempt to discover, understand and satisfy the expressed needs of customers and a 'proactive market orientation' which is related to latent needs. Hurley and Hult (1998) argued that market orientation and innovation orientation should complement each other. A 'proactive market orientation', focused as it is on latent needs, leads to even deeper insight into customer needs and, thus, to the development of innovative services ( Narver et Al, 2004). As Narver et Al state as superior customer benefits become parity over time, responsive market orientation will become much more common over time and to maintain a competitive advantage, proactive market orientation must increase continually which will assure the satisfaction of its target customers' expressed and latent needs.

In addition, focusing on market orientation for educational services, Oplatka and Hemsley- Brown (2007) state that market orientation has been largely neglected in the educational marketing research genre, and call for this to readdressed in future research projects. For educational institutions, market orientation is suggested as a way of linking institutional objectives with the needs of students and employers because it forces the institution to focus on customer identification ( Owlia and Aspinwall 1997). A market-oriented university situates the success of universities in the context of their ability to proactively meet the needs of the stakeholders : students, family, employers, government and citizens (( Nkamnebe and Azikiwe 2008); Lindsay and Rogers (1998)) argue that many higher institutions tend to adopt a sales orientation rather than a market orientation and consequently market orientation has been misconstrued by these educational institutions. To the same effect, Maringe and Gibbs ( 2008) state that one of the new lessons universities is learning about business and commercial world today is how to develop a customer perspective. With the same meaning, Nicolescu (2009) states that the use of the concept of consumer behavior and the study of the consumers' behavior, with the buying decision process, is one way to fulfill the marketing core goal.

\subsection{The linkage between a 'proactive market orientation' and 'service innovation' in the postgraduate educational market}

On the one hand, the connection between 'market orientation' and innovation has been argued by many authors. Baker ( 1994) suggests that 'market orientation' facilitates the anticipation of the developing needs of customers and to respond to them through the addition of innovative products and services. He considers a market orientation as a learning orientation which leads to innovation. According to Sundbo ( 1997), the market situation is the point of departure for the innovation process in services .Voorhees (2005) remarks that it is necessary to use different techniques to assess the market potential of new programs. Among them, he proposes surveys to prospective students( like the ones which we will be propose in our model) and current students. Galic (2012) also considers that successful educational institutions in 
their strategic planning rely on investigations of market segments of future students. Kotler and Keller (2009) also state that formulating a postgraduate institutional marketing strategy includes among others, decisions about the institution's current programs and future new programs (product innovation) as well as designing the rest of the marketing mix (other types of innovation) ( Kotler and Keller, 2009). All the research techniques for assessing the market potential of new programs (innovation) merit serious consideration ( Voorhes 2005). Also Maringe and Gibbs (2009) point that it is vital to conduct researches in order to both, understand the students 'likes and dislikes so universities can design new courses and to assure the quality expected by them. Aspects such as student expectations and student choice are characteristic of consumer behavior in postgraduate and are seen as a valuable source of information( Sander et al, 2000). As Vrontis (2007) state about the Higher Education market, empashis must be given to understanding consumer behavior ( student) and related theory focuses such as services marketing theory. The new era demands a re-interpretation of HE institutions' product ( education) through the eyes of the customer. Hult and Hurley (2004) model 'market orientation' as an antecedent of an innovative culture. To the same effect, in the literature on service innovation, it is also widely argued that the considerations of customers, competitors and market possibilities is usually the point of departure for innovation processes (Brentani 1989; Morgan and Sturdy,1993; Laing 1993; Jallat, 1994).) .Some researchers also suggest that customer involvement is important in service innovations( Jallat, Prs and Dussart, 1992).

On the other hand, when considering postgraduate education, we can state that it has all the characteristics which catalog it as a service where the universities, employers and the adult students have an important role because they participate in the process (Kotler and Fox 1995).

Pestek and Pasic (2008) also state that It can be viewed as a purchase of service, with universities and faculties as service sellers and adult students as customers.

As a result, when reviewing about this particular educational service, we have found in our review, different considerations of types of innovations. ( fig. 1)

\begin{tabular}{|l|l|}
\hline TYPES OF INNOVATION & Author \\
\hline 1. - Educational innovations at the & Lubienski (2003) \\
classroom level, involving teaching & \\
and learning. & \\
2. - Product Innovations which often & \\
include a new substantial different & \\
service offered to students, such as a & \\
curriculum package or other & \\
programmatic option on focused on & \\
3. -Process innovations foch & \\
production and delivery techniques & \\
such as online learning. & \\
4.- Administrative innovations & \\
included about marketing and other & \\
\hline
\end{tabular}




\begin{tabular}{|l|l|}
\hline organizational innovations. & \\
\hline $\begin{array}{l}\text { 1. - Product innovation: new or } \\
\text { significantly improved curriculum.... }\end{array}$ & OECD/ CERI ( 2010) \\
2. -. Process innovation: significant & \\
changes in techniques or equipment & \\
and software in delivering services. & \\
3. - Marketing innovation: a new & \\
marketing method involving significant & \\
changes in product design or & \\
packaging, product placement or & \\
pricing the education service or a new & \\
admission strategy). & \\
4. - Organizational innovation: a new & \\
way organization of work between & \\
teachers or organizational changes in & \\
the administrative area. & \\
\hline $\begin{array}{l}\text { 1. - Academic Research. } \\
\text { 2. - Administrative process. }\end{array}$ & \\
3. - Faculty and staff. & \\
4. - Market development. & \\
5. - Organization structure. & \\
6. - Organizational culture. & \\
7. - Leadership style. & \\
\hline
\end{tabular}

Figure 1 Adapted from the authors

As mentioned before, there are multiple stakeholders which participate in the decision making process for postgraduate programs. So when considering a proactive market orientation we should take into account the relation between adult students, their employers or companies and lastly the personnel from postgraduate institutions, faculty and staff working( Kotler and Fox, 1995 ). A deeper reflection about how to take into account all these different stakeholders should be considered when establishing a market orientation approach to innovation as seen in figure 2.

It is necessary to consider that in some cases the Adult Student takes the decision to enroll a postgraduate program without his/her employer participation so the employer does not always have to be present in the decision-making process but in some. 
Stakeholders involved in the Postgraduate Market

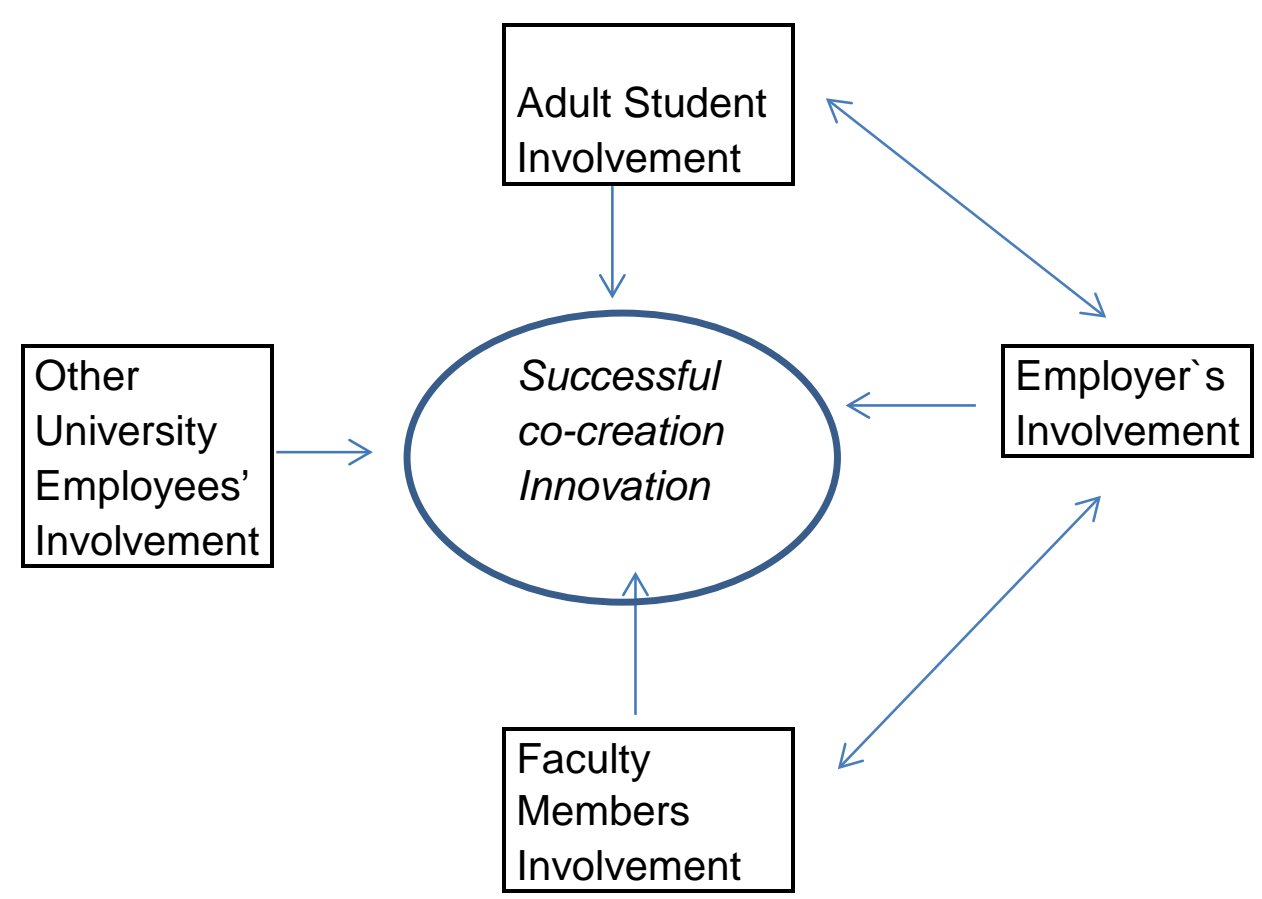

Figure 2 : own elaboration

Focusing on the innovative concept for these higher education institutions, Voorhees (2005) states that more energy is expended on maintaining an inventory of existing programs than on adjusting them or even creating new ones ( innovation) to better meet market needs Therefore, in order for the educational institutions being able to meet contemporary requirements of an ever-changing educational environment, it is necessary that it becomes subject to change and initiate them on its own ( Dordevic-Boljanovic, 201).

Innovation, as a way of differentiating, will be crucial in a complex moment like the one described in the educational market. Binsardi and Ekwulugo (2003) claimed that " a centrally important principle of marketing is that all marketing activities should be geared towards the customer". In order to have a successful innovation policy, the educational institutions will need first to improve their knowledge about the adult students and the company's needs through the pertinent research about consumer decision-making process as we will consider in this paper. 
To conclude, after this review about 'market orientation' and 'innovation' for the postgraduate market, it is obvious that the first step is to get a deep understanding of these adult students ' behavior through a literature review. This would be the first phase for a real 'market orientation' philosophy for postgraduate institutions which will lead us to a successful innovation policy as we will review in this paper.

\subsection{The postgraduate decision making process}

When reviewing the literature about the adult student and their decision for a postgraduate program, we have discovered that there is no decision making model developed for them. Consequently, one of the first things needed to be designed is the 'decision making process' for these adult students when choosing a postgraduate program with the influential drivers which affect each of its phases. To create this decision making model for adult students, we have analyzed both the literature about existing models for undergraduate studentchoice and the literature and surveys related to the choice and enrollment process by the professionals in postgraduate education.

The university market has been characterized as forming three main segments: international students, high school leavers and mature students (considered as "adult students" in this paper) and each segment considers different factors when making choices ( Soutar et Al 2002). For postgraduate programs ( named graduate in USA) we include masters level programs ( Masters or science, art or MBA) and doctoral programs for both research (PhD) or professional activities ( e.g.: medical).

Researches recommended that programs of higher education should be marketed on the basis of service marketing ( Umashankar 2001). Hence, the postgraduate education has all the characteristics which catalog it as a service. It can be viewed as a purchase of service, with universities and faculties as service sellers and adult students as customers ( Pestek and Basic 2008). These adult students are the customers in the process with a consideration, the education is chosen and paid by them or it is paid by their company, therefore in some cases there is a triangular relation among the University, the Company employee / student and Company employer ( Kotler and Fox 1995). ( As seen in fig 2)

The process in which customers make decisions to purchase goods or services is defined as multi-stage and complex process undertaken consciously, and sometimes unconsciously by students aiming to enter higher education, and wherein the issue of the choice of studying destination and the content will be resolved ( Maringe and Carter, 2007).Choosing a postgraduate program ( masters and doctoral) at an ideal institution is probably one of the most important decisions students and their family will make ( Lei et Chuang 2010). Many student applicants find the decision making process to be quite stressful and time-consuming ( Poock and Love, 1997). It is what Nicholls describes as an extended decision process involving complex buying behavior that is subject to multiple influences and high levels of involvement that result from expense ( time and money), significant brand differences, and infrequent buying (Donaldson and McNicholas, 2004; Briggs and Wilson, 2007). This 
process consists of 5 different steps: need recognition, search for information, evaluation and selection, purchase and post purchase behavior ( Neal 2003). A multitude of college choice models ( undergraduate students) has drawn upon the "Model of Consumer Decision Making as a foundation" (Chapman, 1986; Stage and Hosler, 1987; Hosler and Gallagher, 1989). To select the program and the school, the adult student moves through each stage of the buying decision process. The choice process takes a considerable time and there are a number of influencers (Donaldson and McNicholas, 2004) and internal and external factors influencing those stages as mentioned (influential drivers in our proposal).

While students select an undergraduate institution for a variety of immediate reasons ( e.g: student life options, friends...) the selection of an institution for postgraduate study is more closely tied to the benefits students expect to receive upon completion of the graduate degree So it is necessary to distinguish the process for undergraduate students ( under 18 ) from the process of professionals when going back to study while they continue working ( part time postgraduate education).

This is something that allows us for the development of a specific model for the postgraduate choice decision. In order to create our conceptual model for adult students, we are going to analyze both, the literature about existing models for higher education student-choice and the literature and surveys related to the professionals and postgraduate education.

Models of student enrollment behavior theory started to emerge in early 1980 . An extensive body of literature relates to school choice decisions at the undergraduate level. Although models have been developed for undergraduate students when choosing the university or college, none has been addressed for post graduate studies for professionals, adult students, when choosing to attend a part time program. In fact, literature regarding the basis of postgraduate decisions is scarce. It is curious that such an important market has little research (Sanchez Herrera et Al, 2009).

Considering the mentioned undergraduate decision making models when choosing a university, a number of researchers have developed different ones which can be classified in economic models ( Hosler et Al, 1999; Manki and Wise, 1983) , status attainment models ( Sewell and Shah, 1978) and combined models ( Chapman, 1986 and Hanson and Litten, 1982 ) which integrate the two previous approaches. The last and most important models developed are referred to Vrontis and Perna. Vrontis model integrates all the previous models provided considering the three most representative combined models developed ( Chapman, 1986; Jackson and Hanson and Litten, 1982) and compacts them into a comprehensive and more user-friendly version ( Vrontis et $\mathrm{Al}, 2007)$. Also Perna (2008) represents one of the further ones of the combined models introducing the important factor of individual preferences which arise as a result of social circumstances and different family background.

These combined models which provide the best comprehensive explanation about the university decision will be the base for developing the first decision process model for postgraduate studies for professionals. In our model we will represent both the decision steps and the various influential drivers adapting them to the postgraduate decision making process considering the 
information about this market. So, the university models we have considered in order to adapt them for our model are the ones from Vrontis (2007), Vossentsteyn, (2005) and Perna (2008).

Maringe and Carter ( 2007) state that the decision making process and the choice are inseparable concepts and both are affected by different factors : environmental, organizational and individual influences and personal factors that describe the personal system of values and preferences. These factors are frequently viewed in line with the consumer behavior model with all its known phases, where students are faced with different external stimulus such as institution-controlled marketing, attributes and uncontrolled factors, such as personal influence of parents and friends (Alves and Raposo, 2001). Consequently, in all these models, the authors identify different factors, influential drivers or explanatory variables, which influence the different phases of the process and lead us to include the following "influential drivers" in our model: 1. General Environment: economic, demographic and public policy 2. Media 3 Significant Others. 4. - Employee student demographic characteristics 5. - Employee student Personal attributes 6. - Postgraduate institutions: characteristics and actions. 7. Company employer. ( Hanson and Litten 1982, Chapman 1998, Vossenteyn 2005, Vrontis 2007, Perna 2008 ).

\section{5.-Results}

The postgraduate education institutions are facing an increasingly complex competition due to the today's tough economic situation, the global economy and the introduction of online education programs and institutions all around the world. Consequently, universities have to develop differentiation strategies in order to be able to survive in this complex market which has two different targets, adult student and its employer.

The first step in order to develop a real differentiation strategy, is to get a real proactive market orientation. This will help us to get to a successful innovation policy to satisfy these adult students and employers' needs. In our review we have discovered that there is much to be done about a proactive market orientation for the educational institutions when consider this postgraduate market. As a result, little is known about the decision making process of this adult student which will be the first needed step in this proactive market orientation.

The result of our paper, as it has been described, is the first step to develop that future innovation strategy with the proposal model of the decision making process for this adult student. This proposal model should be discussed among experts to improve it before deciding the definitive one which will be needed to be tested future researches. The spectrum of elements it encompasses requires separate studies to test different parts as it happened in the main models created in the past.

The core of our model consists of the different phases of the consumer decision making model but reduced from seven to five the number of steps as 
the ones developed for undergraduate students. The model also shows all the different factors ( influential drivers) which affect each of the phases of the decision making process for postgraduate programs. To select these factors we have considered the ones from Vrontis ( 2007) model and Perna (2008) one adapting them to our adult student after considering the literature about this particular market. To illustrate, Olson and King (1985) state that the undergraduate student process differs from the postgraduate one, adult students, which tends to have additional constraints such as educational and living expenses, family and peer influence, and employment opportunities for the applicants or spouse). Also, the influential drivers differ from the undergraduate ones in different considerations. To illustrate it, Richard and Stacey (1993) argue that the university and program decision should closely match personal, academic and career goals of adult students. 
Postgraduate decision-making process model

\begin{tabular}{|l|}
\hline INFLUENTIAL \\
DRIVERS \\
On \\
the process \\
\hline
\end{tabular}

STAGES

in the

PROCESS

\section{General Environment}

Media

Influencers

or

Significant others

Employee-student

Demographic

Characteristics

Employee-student

personal attributes

Company Employer

Postgraduate institutions

Characteristics and

actions

Postgraduate financial

Aid
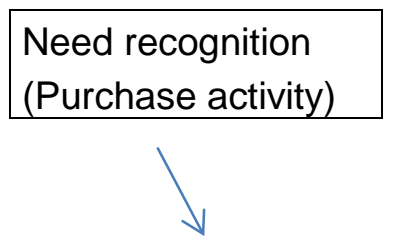

\section{Search}

Behavior

(Purchase activity)

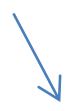

Evaluation

of alternatives

(Purchase activity)

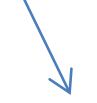

\begin{tabular}{|l|}
\hline Choice and \\
purchase \\
(Consuming activity) \\
\hline
\end{tabular}

Post purchase

Behavior

(Disposing activity)

Figure 3: adapted from Hanson and Litten (1982), Chapman (1998), Vossenteyn (2005), Vrontis (2007), Perna, (2008).

This model will be the first and necessary step to increase the knowledge and information about professionals when going back to school. It will be also the base to decide future researches in any particular part of it. All with the aim to get information from the universities and business schools to innovate and to 
satisfy students' needs in a better way. This knowledge will be really useful for the universities and postgraduate schools to formulate their marketing strategies. As Vrontis ( 2007) explains the student decision-making model has the use to assist administrators in the higher educational institution to market themselves more effectively to their prospective students.

\section{6.-Concluding proposals}

This paper has been organized as follows: We have described first the methodology followed based on a systematic review of existing literature. Second, we have gone rigorously through a literature review, focused mainly on proactive market orientation and the adult student consumer behavior in the postgraduate market. This review was necessary as the first step for developing a framework which could be useful to achieve a differentiation strategy among universities based mainly on innovation. We have also considered the concepts of service innovation and innovation for educational institutions. Finally we have presented our proposed model for the adult student decision making process.

When considering our final conclusions we have reviewed the main objectives we had with this paper.

The reviewer has been developed as mentioned presenting all the information which we have considered remarkable about a "proactive market orientation' and the "postgraduate decision making process" for the adult student.

Also it has been remarked the importance for postgraduate institutions for managing themselves under a "proactive market orientation" as the way to develop a successful innovation policy in order to get the needed differentiation.

Lastly, and as a consequence of the literature review, we have developed a proposal model for the decision making process for this adult student, something that we could consider as management innovation in itself after being discussed and consequently improved.

For future researches, considering our literature review, we have found out that It has also been clearly recognized that successful new product development ( product innovation) depends on a deep understanding of present and latent consumer needs based on a proactive market orientation. With this objective, we have proposed a model for understanding this adult student decision-making process. Our proposal model for this adult student needs further researches in both defying the definitive model and testing it.

Moreover, we suggest that other priorities for future researches must be focused on the co-creation concept as a source of innovation for education institutions based on the multiple stakeholders that participate in the postgraduate market as seen in figure 2. The experience of co-creation innovation in other markets should be considered in order to search for possibilities to be implemented in the educational sector. As Kristensson et Al ( 
2008) argues that the identification of key strategies through which successful co-creation might occur is important to managers attempting to apply the philosophy of market orientation in a proactive way.

\section{7.-References}

Alves $\mathrm{H}$, Raposo M. Conceptual model of student satisfaction in higher education. Total Qual Manage. 2007;18(5):571-588.

Baum S, Ma J, Payea K. Education pays, 2010: The benefits of higher education for individuals and society. trends in higher education series. College Board Advocacy \& Policy Center. 2010.

Binsardi A, Ekwulugo F. International marketing of british education: Research on the students' perception and the UK market penetration. Marketing Intelligence \& Planning. 2003;21(5):318-327.

Bradshaw D. Business school rankings: The love-hate relationship. The Journal of Management Development. 2007;26(1):54-60.

Briggs S, Wilson A. Which university? A study of the influence of cost and information factors on scottish undergraduate choice. Journal of Higher Education Policy and Management. 2007;29(1):57-72.

Bruce GD. Exploring the value of MBA degrees: Students' experiences in fulltime, part-time, and executive MBA programs. Journal of Education for Business. 2009;85(1):38-44.

Chapleo C. Interpretation and implementation of reputation/brand management by UK university leaders. Case International Journal of Educational Advancement. 2004;5(1):7-23.

Chapman R. Towards a theory of college selection: A model of college search and choice behaviour. Advances in Consumer Research. 1986;13(1):246-250.

Chen JK, Chen I. Using a novel conjunctive MCDM approach based on DEMATEL, fuzzy ANP, and TOPSIS as an innovation support system for taiwanese higher education. Expert Syst Appl. 2010;37(3):1981-1990.

Chia A. A study of the factors influencing students' selection of a private educational institution in singapore and the marketing implications for the institution. . 2011.

Daley S, Wingard DL, Reznik V. Improving the retention of underrepresented minority faculty in academic medicine. J Natl Med Assoc. 2006;98(9):1435.

Day GS. The capabilities of market-driven organizations. the Journal of Marketing. 1994:37-52. 
Díaz-Martín AM, Iglesias $V$, Vázquez $R$, Ruiz AV. The use of quality expectations to segment a service market. Journal of Services Marketing. 2000;14(2):132-146.

Donaldson B, McNicholas C. Understanding the postgraduate education market for UK-based students: A review and empirical study. International Journal of Nonprofit and Voluntary Sector Marketing. 2004;9(4):346-360.

Đorđević Boljanović J, Stanković J. The role of knowledge management in building client relationships. Singidunum Journal of Applied Sciences. 2012;9(1).

Enache I. Marketing higher education using the 7 ps framework. Bulletin of the Transilvania University of Braşov• Vol. 2011;4(53).

Espinoza S, Bradshaw G, Hausman C. The importance of college choice factors from the perspective of high school counselors. College and University. 2002;77(4):19-23.

Ginsburg M, Espinoza O, Popa S, Terano M. Privatisation, domestic marketisation and international commercialisation of higher education: Vulnerabilities and opportunities for chile and romania within the framework of WTO/GATS. Globalisation, societies and education. 2003;1(3):413-445.

Haigh MJ. Internationalisation of the curriculum: Designing inclusive education for a small world. Journal of Geography in Higher Education. 2002;26(1):49-66.

Hanson KH, Larry H. Litten, 1982.". Mapping the Road to Academe: A Review of Research on Women, Men, and the College-Selection Process." In The Undergraduate Woman: Issues in Educational Equity, edited by Pamela J.Perun.Lexington, Mass.: DC Heath and Company.

Hegarty N. Adult learners as graduate students: Underlying motivation in completing graduate programs. The Journal of Continuing Higher Education. 2011;59(3):146-151.

Heiens RA. Market orientation: Toward an integrated framework. Academy of Marketing Science Review. 2000;1(2000):1-4.

Hemsley-Brown J, Oplatka I. Universities in a competitive global marketplace: A systematic review of the literature on higher education marketing. International Journal of Public Sector Management. 2006;19(4):316-338.

Hunt SD, Morgan RM. The comparative advantage theory of competition. The Journal of Marketing. 1995:1-15.

Hurley RF, Hult GTM. Innovation, market orientation, and organizational learning: An integration and empirical examination. The Journal of Marketing. 1998:42-54. 
Jarvis P. Globalisation, the learning society and comparative education. Comparative education. 2000;36(3):343-355.

Kallio RE. Factors influencing the college choice decisions of graduate students. Research in Higher Education. 1995;36(1):109-124.

Kotler P, Fox KFA. Strategic marketing for educational institutions. . 1995.

Kotler P, Keller K, Brady M, Goodman M, Hansen T. Marketing management: First european edition. Pearson; 2009.

Kotler P, Keller KL. Dirección de marketing. Prentice Hall; 2009.

Kotler PK. K., 2006, dirección de marketing.

Lei SA, Chuang NK. Demographic factors influencing selection of an ideal graduate institution: A literature review with recommendations for implementation. College Student Journal. 2010;44(1):84-96.

Lindsay G, Rodgers T. Market orientation in the UK higher education sector: The influence of the education reform process 1979-1993. Quality in Higher Education. 1998;4(2):159-171.

Litten LH. Different strokes in the applicant pool: Some refinements in a model of student college choice. The Journal of Higher Education. 1982:383-402.

Lubienski C. Innovation in education markets: Theory and evidence on the impact of competition and choice in charter schools. American Educational Research Journal. 2003;40(2):395-443.

Lundberg CA. The influence of time-limitations, faculty, and peer relationships on adult student learning: A causal model. Journal of Higher Education. 2003:665-688.

Maringe F. University and course choice: Implications for positioning, recruitment and marketing. International Journal of Educational Management. 2006;20(6):466-479.

Maringe F, Gibbs P. Marketing higher education: Theory and practice. Open University Press; 2008.

Mavondo FT, Tsarenko DY, Gabbott M. International and local student satisfaction: Resources and capabilities perspective. Journal of Marketing for Higher Education. 2004;14(1):41-60.

Möller AM. The case for open access publishing, with special reference to open access journals and their prospects in South Africa. 2006. 
Mouwen K. Strategy, structure and culture of the hybrid university: Towards the university of the 21st century. Tertiary Education \& Management. 2000;6(1):4756.

Narver JC, Slater SF, MacLachlan DL. Responsive and proactive market orientation and New-Product success*. J Prod Innovation Manage. 2004;21(5):334-347.

Nicolescu L. Applying marketing to higher education: Scope and limits. Management \& Marketing. 2009;4(2):35-44.

Perna LW. Understanding high school students' willingness to borrow to pay college prices. Research in Higher Education. 2008;49(7):589-606.

Poock MC, Love PG. Factors influencing the program choice of doctoral students in higher education administration. Journal of Student Affairs Research and Practice.

Riana KE, Zuhairi A, Maria M. The decision-making process of distance education students at universitas terbuka in indonesia'. Asian Journal of Distance Education. 2006;4(1):20-33.

Schimmel K, Motley D, Racic S, Marco G, Eschenfelder M. The importance of university web pages in selecting a higher education institution. Research in Higher Education Journal. 2010;9:1-16.

Schools B. GMAC $\circledast 2010$ global management education graduate survey. .

Shattock M. Managing successful universities. Open University Press; 2010.

Simões C, Soares AM. Applying to higher education: Information sources and choice factors. Studies in Higher Education. 2010;35(4):371-389.

Soutar GN, Turner JP. Students' preferences for university: A conjoint analysis. International Journal of Educational Management. 2002;16(1):40-45.

Sundbo J. Management of innovation in services. Service Industries Journal. 1997;17(3):432-455.

Tranfield D, Denyer D, Smart P. Towards a methodology for developing evidence-informed management knowledge by means of systematic review. $\mathrm{Br}$ J Manage. 2003;14(3):207-222.

Umashankar $\mathrm{V}$. The importance of managing points of marketing in marketing higher education programmes-some conclusions. Journal of Services Research. 2001;1(1):122-137. 
Veloutsou C, Lewis JW, Paton RA. University selection: Information requirements and importance. International Journal of Educational Management. 2004;18(3):160-171.

Voorhees RA. Institutional research and new program development. New Directions for Institutional Research. 2005;2005(128):29-39.

Vossensteyn H. Student grants and access in higher education. . 2005.

Vrontis D, Thrassou A, Melanthiou Y. A contemporary higher education studentchoice model for developed countries. Journal of Business Research. 2007;60(9):979-989.

Zhang D, Cooper WL. Revenue management for parallel flights with customerchoice behavior. Oper Res. 2005;53(3):415-431. 


\section{CAPÍTULO 3}

TOWARDS A MODEL OF CO-CREATION INNOVATION FOR MASTERS PROGRAMS IN THE POSTGRADUATE MARKET FOR UNIVERSITIES 


\title{
Towards a model of co-creation innovation for masters programs in the postgraduate market for Universities
}

Gabriela Ribes Giner. Universitat Politècnica de Valencia. Valencia, España Agustín Peralt Rillo. Universidad Europea de Valencia. Valencia, España.

Ismael Moya. Universitat Politècnica de Valencia. Valencia, España

\begin{abstract}
The present study aims at creating a model for innovation to help universities get through a strong innovation policy for their postgraduate programs based on the co-creation innovation paradigm for Entrepreneurial Universities.

Through a comprehensive literature review of the concepts of proactive market orientation for educational innovation and co-creation innovation, we have identified the possibility of creating a framework for improving the innovation among those institutions for this particular segment of postgraduate students. This model could be a perfect tool in order to facilitate different reflections about customers, companies, universities and all the possible interactions which can exist under the co-creating innovation paradigm. This interaction process and communication between students, companies and university are key for a customer co-creation philosophy which leads to successful innovations. This study makes a significant contribution to the body of knowledge in the area of entrepreneurial universities related to the particular subject of innovation.

Educational institutions can assist the University, administrators, managers and recruiters in adapting their marketing strategies, and their related innovation policy in order to differentiate from the competition in a complex sector like the postgraduate education one.
\end{abstract}

Keywords: co-creation innovation, university, masters programs, postgraduate 


\section{1. -Introduction: Trends in the market of postgraduate education}

Certain issues in our world nowadays have made attracting students to postgraduate programs more complicated. For instance, competition has greatly increased due to the economic situation, global economy and more online offer. This situation requires that universities become more active as far as offering more attractive programs that meet the students' needs and expectations and even influence the students' selection of a suitable postgraduate program. One of the challenges faced by postgraduate institutions is catering to the needs of a growing segment of more mature students from nontraditional backgrounds, international students, and students who enroll to achieve very specific objectives( Mavondo et al 2004, Veloutsou et al 2004, Lundberg 2003). Postgraduate marketing research still has a long way to go. Perhaps one of the best ways to approach this market could be to segment the market place which would give you the opportunity to find out the needs and, then, produce educational products which satisfy those needs. Considering the need for universities to pay attention to the market thorough a market oriented approach, the research has been focused on undergraduate students when choosing their college. Due to the increasing changes in the demographics of the student population and the needs of the current workforce, it is necessary for these institutions get a deeper understanding of the decision making process among professionals for postgraduate education programs in order to create the appropriate marketing strategy (Simoes and Soares, 2010). If we consider the area of postgraduate studies, little is known about the antecedents involved in the development of postgraduate intentions. In addition, considering the demand, consumers (companies' and their professionals' evolutional educational needs), there has been an increasing demand in the last decade of post graduated programs (GMAC, 2010).

This opportunity proves to be very motivating for employees. Employers often times reimburse the full cost of the postgraduate program and, at the same time, consider it as a fringe benefit for their employees. The very fact that employers look upon postgraduate training as a way to professionalize and motivate their employees suggests that universities should tailor their marketing strategies to fit the needs of companies. There appears to be a lack of research on students studying part-time postgraduate programs, and there is evidence that most universities are only concerned with the number of postgraduate programs they offer and not necessarily if these programs are actually adequate as far as meeting the market's needs.

To this end, innovation, as a way of differentiating, will be crucial in a complex moment like the one described in the educational market.

The purpose of this study is to offer a model that facilitates innovation for postgraduate institutions as they develop programs under the concept of cocreation ( university and adult student and employers), and its necessary proactive market orientation. First, we provide a comprehensive literature review related to 'entrepreneurial universities' and 'innovation for higher education institutions' and the 'co-creation innovation' paradigm. Second, we use the Delphi technique to further validate the analysis of literature and 
develop a model, that facilitates innovation for postgraduate institutions for their postgraduate programs, under the concept of co-creation (university-adult student- employers). We believe that such a model has the ability to provide different ways to facilitate the innovation process in a coherent way and help universities to become more entrepreneurial.

\section{2.- Literature Review}

\subsection{The linkage between Entrepreneurial Universities, market orientation and Innovation}

Postgraduate education, can be considered as a service where the universities, employers and the adult students have an important role because they participate in the process .Globally speaking, post-graduate programs have turned into a big business especially in the United States where an important percentage of the country's service sector is employed in them.

It has been suggested that developing proper postgraduate programs relies heavily on discovering exactly what the customers need and how to innovate current programs.

Heiens (2000) suggests that in market orientation, firms should seek to understand both customers and competitors and to incorporate such knowledge in their strategic planning efforts. Focusing on the higher education market, Kotler (1995) proposed that in the educational sector the only consideration of the product innovation approach, is that the new products have to be created to satisfy two different needs, the students' and employers' ones. It is highly accepted that the sector has multi-clients, as students, employers and society are seen to be the main beneficiaries of postgraduate services (Maringe, 2006). While students are the primary consumers, employers can be seen as secondary or indirect consumers of postgraduate services (Nicolescu, 2009). So as Taylor and Reed (1995) noted, marketing of postgraduate does not mean taking a totally student-centric perspective, but rather that the needs of various stakeholders need to be balanced.

Chapleo (2004), stated that there is a lack of real differentiation in the educational sector in general. He considers that in spite of the similarity of products offered, key factors could be pursued by universities to occupy positions of distinctiveness. In this increasing competitive situation, it is obvious the need for strategies that lead the sector. Moreover, Nicolescu (2009), posed that the marketing field is still to be developed and adapted for the postgraduate sector, and that in addition to the promotion and communication, there are many other actions for satisfying the student which have to be considered. Also, Temple and Shattock (2007), noted that most universities are actually doing (or they say are) very like most other universities. Enache and Casatas (2011), suggested that a framework able to provide relevant information and suitable instruments will improve the market presence of any postgraduate institution. To the same effect, Maringe and Gibbs (2009), found that one of the new lessons universities are learning from business and the commercial world today is how to develop a customer perspective. Voorhees (2005), indicated that it is necessary to use different techniques to assess the market potential of new programs. Kotler and Keller (2009), also stated that formulating a postgraduate 
institutional marketing strategy includes among others, decision about the institution's current programs and future new programs (product innovation) as long as designing the rest of marketing mix (other types of innovation). It cannot be emphasized enough the need for research into the necessities and preferences of students in order for universities to provide quality postgraduate programs which meet their expectations.

This knowledge and information about their potential clients will let the educational institutions understand the different segments and target the chosen ones with the right proposition strategy and its correspondence marketing mix policies (Kotler \& Keller, 2007). According to research conducted by GMAC, institutions whose marketing plan takes into account the needs and expectations of the customers have more possibilities of being successful. It is important for the institutions to know exactly what the students are looking for when they choose a program.

The literature review yielded relevant information regarding this particular view of post graduate education as an educational service. The present study recognizes the relevance of utilizing market orientation and differentiation as a way of innovation in higher education. The authors propose that this knowledge enables university administrators to gain a better understanding of graduate students so that they can improve their marketing techniques to more effectively recruit and retain goal-oriented students who can successfully achieve their degree

\subsection{Co-creation Innovation}

Prahalad and Ramaswamy (2004), introduced the co-creation concept as a unique way to creating value for customers. They insisted that companies can no longer act autonomously, designing products, developing production processes with little or no interference from consumers. Consumers want to interact with firms and thereby co-create value. The consumer plays an important role in the design of the products and their value. Firms gain a lot by conducting surveys to see what degree of satisfaction their customers have. This allows firms to integrate their customers into the creation process of the products and thus provide programs which genuinely meet their needs and expectations. This is quite different from the old passive process which merely presented the products to the customers for them to choose. In this proactive market orientation, the customer takes part as a collaborative partner, jointly cocreating value with the company. According to Kristenssen et al. (2004), involving users as co-creators during new product development (product innovation), produces ideas that are more creative, more highly valued by customers, and more easily implemented. There can be multiple points of interaction anywhere in the system (including the traditional point of exchange); this new co-creation framework implies that all the points of consumer-company interaction are critical for creating value. From a managerial perspective, this suggests that it is beneficial when working with incremental innovation to spend time with customers, become immersed in the customer's context as much as possible (Wittel et Al, 2003). Companies should create dialogues with 
customers during the value co-creation process and meet and communicate with customers in the customers 'own environment or through various media. Essentially, customer co-creation concerns different ways of communicating and interacting with customers and their context during the value co-creation process (Gustafson et al. 2012) . In Co-creation, from the customers' point of view, other stakeholders are actively involved in the process, employees and even suppliers.

Ramaswamy (2009), introduced another point by saying that sustainable co-creation with customers cannot be accomplished unless value is created for the employees. He insists that employees come in first hand and customers in second hand in the process of co-creation due to the importance of starting cocreation first internally.

In sum, the existing literature clearly emphasizes that customer participation in value co-creation activities should impact their innovation outcomes, such as innovation cost, time to market, new product and development capacity (Bowonder et al. 2010; Kristensson et Matthing, 2008; Nambisan and Baron, 2009; Prahalad and Krishan, 2008; Ramaswamy and Goullart 2010). It has also been suggested that the very universities establish a relationship and become involved with the customers in order to really get to know them and obtain valuable feedback about the programs, especially in the case of new products being created. The customers can become so involved as to actually create and choose parts of a new product.

Finally, the concept of co-creation is of vital importance for our educational market. It is critical that we utilize its potential in the educational services for postgraduate programs where the opinion of adult students, faculty, staff, and employers is key for the process of co-creating of educational programs that are meaningful, efficient, and innovative. As the Fraunhofer Institute Research (2011) research studies found, universities are not still benefiting from the whole potential of co-creation and are not involving their students in the daily business to contribute to improve. Our proposed model is consistent with Witell et al. (2011), who explained that innovations developed through market research techniques based on customer co-creation, are more profitable than those developed with traditional market research techniques. By creating programs that take into consideration not only the student but also the companies' opinions, universities could be more successful in developing new post graduate programs. In summary, considering a broader definition of the concept of innovation ( innovation in all its categories) and the literature reviewed, we have identified an opportunity to find a real differentiation for higher education institutions through a market orientation which will lead them to successful innovations with added value for both adult students and employers. 


\section{3.-Methodology}

The purpose of this study was to develop and validate a framework of cocreation innovation in the postgraduate market. We utilized a two round Delphi Survey. This method has proven to be an effective and valid tool in business research for identifying, prioritizing and validating issues for managerial decision-making by achieving consensus among panelists (Alsmadi and Khan, 2008). Holsapple and Joshi (2000) used a Delphi approach to develop the final framework from an initial one. Lastly, there are many other examples where Delphi panels have been used to validate models: the one leaded by Zhang and Salaba (2009) where they asked the panel members to raise critical issues about their FRBR model for bibliographic records; Tracey and Richey ( 2006) and their model which was reviewed and validated by experts in the field of Instructional Design through a three-round Delphi study. The result was a revised and validated Multiple Intelligences Design Model. Our panelists were faculty and administrative members from universities, adult students who has already participated in a postgraduate program and Human Resources Directors as considered by Kotler \& Keller (2006), as the main participants in the decision making process for adult student when choosing a postgraduate program.

In phase one of the Delphi technique, a packet of information was emailed to each of the reviewers. The packet included an introductory letter with the schedule and directions for study, our proposed model, a set of three openended questions to be answered in written format and a description of the purpose of the study. The reviewers were asked to respond within one week to questions related to: the relation between adult student employer and university members considering the relation proposed by Ribes \& Peralt (2012); information about the adult student or the employer which could be useful in order to have further researches; different types of innovation in higher education which should be considered in this co-creation

In this first round, the panel members were asked to judge both the relations between adult student, employers and university members as the different participants for the co-creation paradigm and also, to propose influence factors or new inputs in order to include in the proposed model. Their written responses were reviewed and grouped together based on the questions asked, the area of the model addressed and miscellaneous feedback. These responses were then summarized by category: (1) changes to be introduced in the relation between the stakeholders; (2) key information to be researched and to be introduced in the model; (3) other types of innovation to be considered

The panel of experts recommended the following revisions in the proposed model:

- It should provide a more detailed relation between the stakeholders in which all the possible relations are considered. The changes are presented in fig 1 
- It should be considered additional researches which should be considered taking into account that the employer is the one which starts the process and even takes the final decision for its employee.

- It should consider also types of innovation related to the relation and the participation of the employer

The main purpose of second round was to confirm the modified framework based on the first round feedback. In the second round, after having introduced the modifications from the first round, they were asked to confirm the overall modified framework. Thus, only a single question was posed. The question asked: "Can you agree with this model?" Each one responded "yes" and Round Two was complete; the Delphi study ended. No further changes were made to Model presented in Fig. 2.

\section{4.-Model}

The model (Fig 2) is presented in a conceptual way in need of further testing. The spectrum of elements it encompasses requires separate studies to test different parts as in the main models created in the past. It has been widely recognized that successful new product development (product innovation), depends on a deep understanding of consumer needs and product development efforts that meet those needs. So it is necessary to consider the decision making process for this adult students when choosing a postgraduate program. The decision making process is the one considered in our previous paper about the postgraduate adult student behaviour (Ribes \& Peralt, 2012). Von Hippel (2005) explains that in customer co-creation, companies need to learn knowledge about customer needs and how to solve customers' needs. For example, Hoyer et al. (2010), in their conceptual framework of consumer co-creation considered consumer motivators as one of the most important drivers of its model. They defend the idea that it is going to be vital to dominate the consumer behavior for being successful in innovation.

Our model starts with adult student consumer behavior as the source of knowledge, which can help in order to innovate in a successful way as a source of a differentiation strategy (Kotler \& Keller, 1996). Also, while considering the co-creation concept of innovation, our model is the first step in order in integrating both the adult student and the employer in this need for innovation in educational market as a way of differentiating. In this final scheme developed, we have tried to reflect all the possibilities, which may exist to connect our new adult decision model and its possibilities of future studies, which may help to create different types of innovation, all under the participation of the main stakeholders: adult students, employers, faculty and university staff. In our model, the point of departure is as mentioned the decision making process and the drivers, which influence each of its phases or stages. These stages will help us to consider the key information we should consider in order to get knowledge for the future innovation policy. Our model is management innovation due to the fact that is the first model which considers this reflection for innovation with the three stakeholders (university, companies-employers and adult student), working together under the co-creation paradigm. In the past, these three stakeholders were considered on an individual or isolated way, one by one but not all together. Thus, when considering a product innovation in the educational sector, working under this co creation framework will help to 
increase the probability of great successful innovations which satisfy everybody needs, and even more when considering the postgraduate programs where some of the adult students' companies are involved. As mentioned before, and as we can see in our fig. 3, our co-creation approach for innovation considers all the stakeholders involved: adult students, employers or companies and personnel from postgraduate institutions, faculty and staff working together under this innovation paradigm. This study resulted in a validated model that should be useable by the administrators of universities in order to innovate under the co creation paradigm.

\section{5.-Conclusion}

The main objective of this study was to propose a model that facilitated innovation for postgraduate programs under the concept of Co-creation (university,adult student and employers), and its necessary proactive market orientation. The proposed model offers, as an output, different types of future innovations, which the postgraduate institutions should consider and indeed, under the co-creation paradigm. We firmly believe that it offers a wide range of possibilities for innovation as a way of differentiation in this complex educational market, in a way where the possibility of success is higher from our point of view. Logically, innovation is crucial in this need for differentiation based on the marketing concept so we consider it as a great possibility for a university, which needs to design its competitive strategy. Firms that manage this co-creation process, effectively will ultimately achieve a competitive advantage over the competition. This competitive advantage will be related to improved productivity and effectiveness with a better fit with customer needs, for example of cocreated products.

The first important key point from our model is that universities involve both adult student and employers in a deep consideration of a proactive market orientation. This co-creation approach is one step forward from the market research techniques. Therefore, with this proactive market orientation, the adult student and employers take a part as collaborative partners co-creating value with the company for both the university and themselves. The relation between these three groups has multiple points of interaction, in which the knowledge about individuals' needs and expectations is generated in order to get a better understanding to satisfy all of these stakeholders, university adult student, employers and universities' staff and faculty. The universities' implications with their customers, adult students and employers, will be based on different communications and interactions regarding both new products and services and all the processes which can occur in this service. With this co-creation paradigm not only the customers ( adult student and employer) may get profit from it but also the universities' staff and faculty who see many benefits and value created also for them in both the successful innovation and the most effective and efficient processes. Our model proves to be a beneficial tool that can help universities benefit from the potential of co-creation in order to have successful innovations. This will also increase the possibility to get a real differentiation in this complex educational market. At the same time, entrepreneurial universities in search for academic and innovation can incorporate this model as part of their innovation policy. This may be an 
important help to develop the entrepreneurial mindset within the university management process meeting all the stakeholders' needs .

Finally, we suggest that one of the highest priorities for future research must be focused on this co-creation concept but from the company's point of view, with the collaboration between companies, in our case the postgraduate institutions. In co-creation, from the company's point of view, it will be necessary to review the desire and possibility for the postgraduate institutions' to co-create value with other institutions because they might not have enough skills, resources and competence to develop it by themselves.

To form the collaboration means the company can access new knowledge, skills and resources. Companies seek to join co-creation where they can combine skill, resource and competence and stay competitive in the marketplace. From a business perspective, this model has the potential to extend this postgraduate program to organizations that seek it for their employees.

Fig. 1 : Stakeholders involved in CO-CREATION Innovation for masters programs

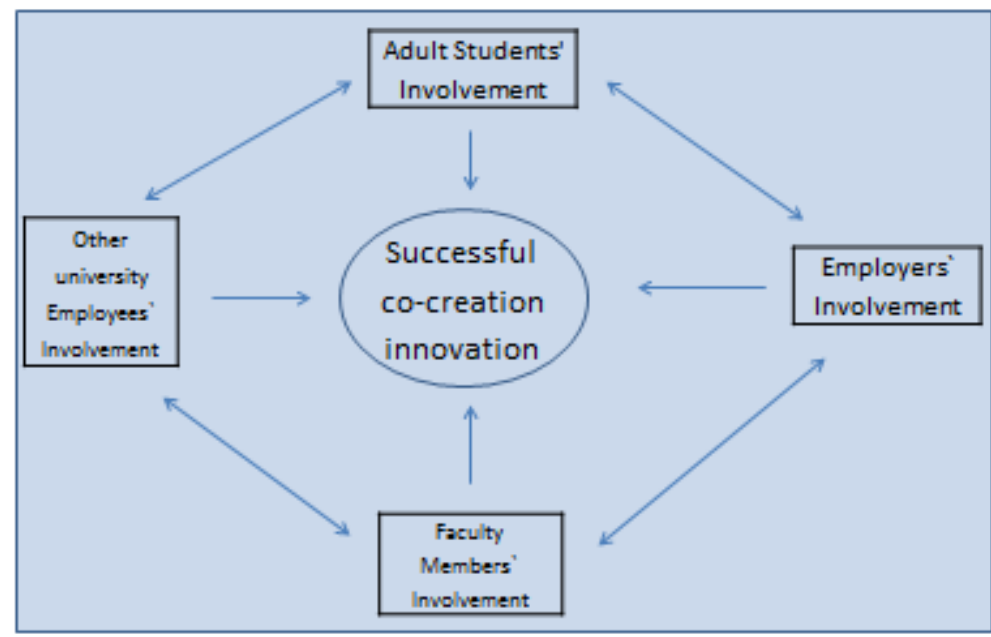

Adapted from Ribes \& Peralt (2012) 
Fig 2 : CO-CREATION INNOVATION Model : Student-Employer-University

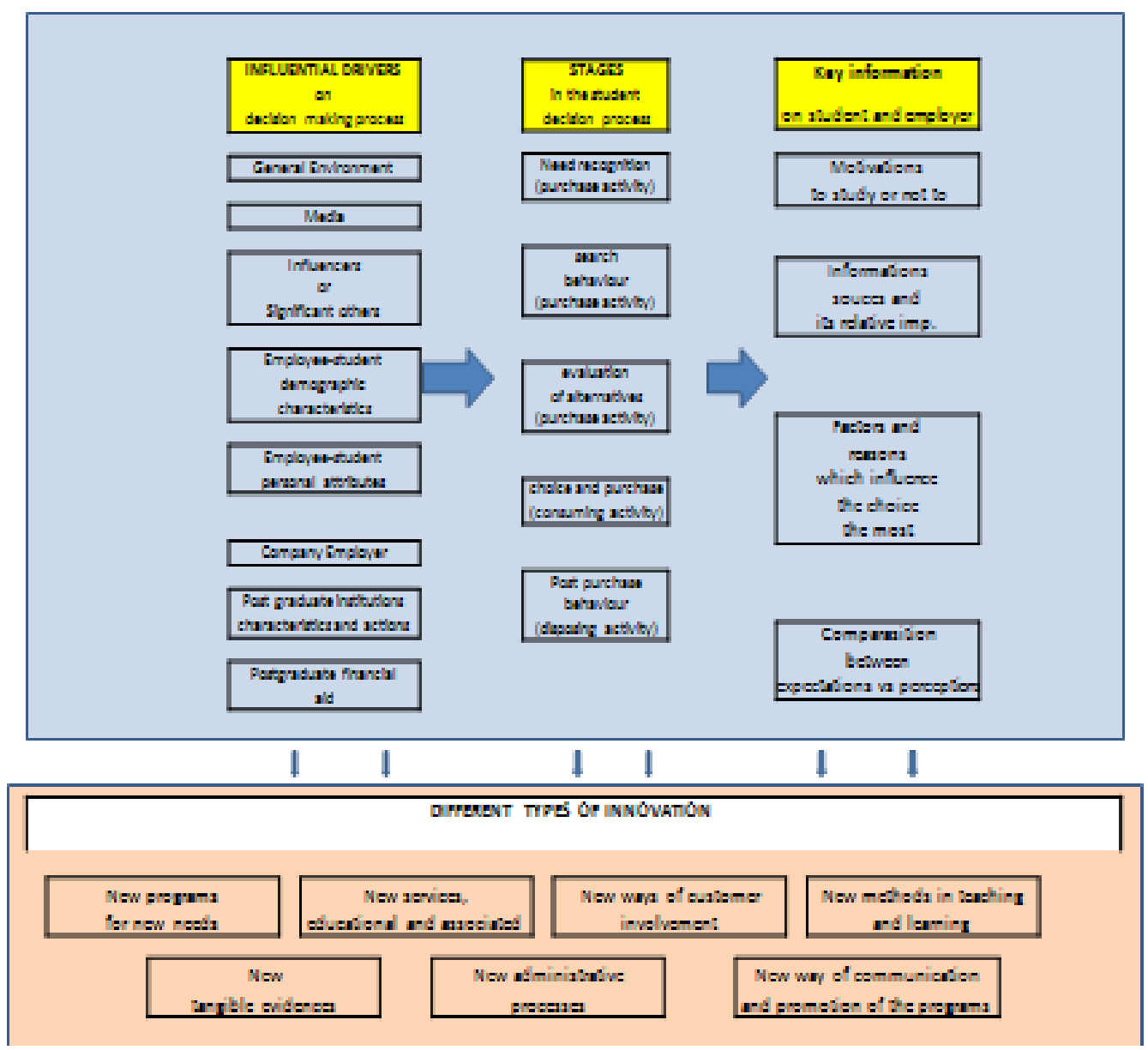




\section{6.-References}

Alsmadi M, Khan Z. Lean sigma: The new wave of business excellence, literature review and a framework. . 2010:1-8.

Binsardi A, Ekwulugo F. International marketing of british education: Research on the students' perception and the UK market penetration. Marketing Intelligence \& Planning. 2003;21(5):318-327.

Bitner MJ, Ostrom AL, Morgan FN. Service blueprinting: A practical technique for service innovation. Calif Manage Rev. 2008;50(3):66.

Bowonder B, Dambal A, Kumar S, Shirodkar A. Innovation strategies for creating competitive advantage. Research-technology management. 2010;53(3):19-32.

Bradshaw D. Business school rankings: The love-hate relationship. The Journal of Management Development. 2007;26(1):54-60.

Briggs S, Wilson A. Which university? A study of the influence of cost and information factors on scottish undergraduate choice. Journal of Higher Education Policy and Management. 2007;29(1):57-72.

Chapleo C. Interpretation and implementation of ReputationBrand management by UK university leaders. International Journal of Educational Advancement. 2004;5(1):7-

Chia A. A study of the factors influencing students' selection of a private educational institution in singapore and the marketing implications for the institution. . 2011.

Clark BR. Creating entrepreneurial universities: Organizational pathways of transformation. issues in higher education. ERIC; 1998.

De Brentani U. Success and failure in new industrial services. J Prod Innovation Manage. 1989;6(4):239-258.

Díaz-Martín AM, Iglesias $V$, Vázquez $R$, Ruiz AV. The use of quality expectations to segment a service market. Journal of Services Marketing. 2000;14(2):132-146.

Enache I. Marketing higher education using the $7 \mathrm{ps}$ framework. Bulletin of the Transilvania University of Braşov• Vol. 2011;4(53).

Espinoza, S., Bradshaw, G. and Hausman, C. The Importance of College Choice Factors from the Perspective of High School Counselors. 2002 
Etzkowitz H. Research groups as 'quasi-firms': The invention of the entrepreneurial university. Research policy. 2003;32(1):109-121.

Gajić J. Importance of marketing mix in higher education institutions. Singidunum Journal of Applied Sciences. 2012;9(1):29-41.

Gallouj F. Innovation in the service economy: The new wealth of nations. Edward Elgar Pub; 2002.

Gibb A. Making markets in business development services for SMEs: Taking up the chinese challenge of entrepreneurial networking and stakeholder relationship management. Journal of Small Business and Enterprise Development. 2006;13(2):263-

Gibb A. In pursuit of a new 'enterprise'and 'entrepreneurship'paradigm for learning: Creative destruction, new values, new ways of doing things and new combinations of knowledge. International Journal of Management Reviews. 2002;4(3):233-269.

Goldstein B, Thorp HH. Engines of innovation: The entrepreneurial university in the twenty-first century. Univ of North Carolina Press; 2010.

Gustafsson A, Kristensson P, Witell L. Customer co-creation in service innovation: A matter of communication? Journal of Service Management. 2012;23(3):311-327.

Hasche N. Developing collaborative customer-supplier relationships through value co-creation. 2006.

Hegarty N. Who we are and whom we teach: Understanding graduate student motivation. Journal of Human Resource Education. 2011;5(4).

Heiens RA. Market orientation: Toward an integrated framework. Academy of Marketing Science Review. 2000;1(1):1-4.

Hemsley-Brown J, Oplatka I. Universities in a competitive global marketplace: A systematic review of the literature on higher education marketing. International Journal of Public Sector Management. 2006;19(4):316-338.

Holsapple C, Joshi K. An investigation of factors that influence the management of knowledge in organizations. The Journal of Strategic Information Systems. 2000;9(2):235-261.

Hoyer WD, Chandy R, Dorotic M, Krafft M, Singh SS. Consumer cocreation in new product development. Journal of Service Research. 2010;13(3):283-296.

Hoyer WD, Chandy R, Dorotic M, Krafft M, Singh SS. Consumer cocreation in new product development. Journal of Service Research. 2010;13(3):283-296.

JALLAT F. Innovation dans les services: Les facteurs de succès. Décisions marketing. 1994:23-30. 
Kirby D. Creating entrepreneurial universities: A consideration. University of Surrey. 2002.

Kotler P, Fox KF. Strategic marketing for educational institutions. . 1995.

Kotler P, Keller K. Marketing management: International edition. . 2009

Kotler PK. K., 2006, dirección de marketing. .

Kristensen T. The physical context of creativity. Creativity and Innovation Management. 2004;13(2):89-96.

Kristensson P, Magnusson PR, Matthing J. Users as a hidden resource for creativity: Findings from an experimental study on user involvement. Creativity and innovation management. 2002;11(1):55-61.

Kristensson P, Matthing $\mathrm{J}$, Johansson N. Key strategies for the successful involvement of customers in the co-creation of new technology-based services. International Journal of Service Industry Management. 2008;19(4):474-491.

Liu SS, Dubinsky AJ. Institutional entrepreneurship-A panacea for universitiesin-transition? European Journal of marketing. 2000;34(11/12):1315-1337.

Maringe F. University and course choice: Implications for positioning, recruitment and marketing. International Journal of Educational Management. 2006;20(6):466-479.

Maringe F. University and course choice: Implications for positioning, recruitment and marketing. International Journal of Educational Management. 2006;20(6):466-479.

Maringe F, Gibbs P. Marketing higher education: Theory and practice. Open University Press; 2009.

Möller O. Student satisfaction survey: The utrecht university approach. . 2006.

Mouwen K. Strategy, structure and culture of the hybrid university: Towards the university of the 21st century. Tertiary Education \& Management. 2000;6(1):4756.

Nambisan S, Baron RA. Virtual customer environments: Testing a model of voluntary participation in value Co-creation activities. J Prod Innovation Manage. 2009;26(4):388-406.

Nicolescu L, Pricopie R, Popescu A. Country differences in the internationalization of higher Education-How can countries lagging behind diminish the gap. Review of International Comparative Management. 2009;10(5).

Nkamnebe A, Azikiw N. Towards market-oriented entrepreneurial university management for nigerian universities. The international journal of management education. 2009;7(2):9-19. 
O'Hern M, Rindfleisch A, Schweidel D, Antia K. The impact of user-generated content on product innovation. Available at SSRN 1843250. 2011.

Prahalad C, Krishnan MMS. The new age of innovation. McGraw-Hill Professional; 2008.

Prahalad CK, Ramaswamy V. Co-creating unique value with customers. Strategy \& Leadership. 2004;32(3):4-9.

Prahalad CK, Ramaswamy $\mathrm{V}$. The new frontier of experience innovation. MIT Sloan Management Review. 2003;44(4):12-18.

Preissl B. Service innovation: What makes it different? empirical evidence from germany. In: Innovation systems in the service economy. Springer; 2000:125148.

Pušina $A$, Bašić $H$, Peštek $A$. Active learning methods in the context of higher education reform. Zbornik radova Ekonomskog fakulteta u Sarajevu. 2008(28):132.

Pušina $A$, Bašić $H$, Peštek A. Active learning methods in the context of higher education reform. Zbornik radova Ekonomskog fakulteta u Sarajevu. 2008(28):132-144.

Ramaswamy V. Leading the transformation to co-creation of value. Strategy \& Leadership. 2009;37(2):32-37.

Ramaswamy V, Gouillart F. Building the co-creative enterprise. Harv Bus Rev. 2010;88(10):100-109.

Ramaswamy V, Gouillart F. Building the co-creative enterprise. Harv Bus Rev. 2010;88(10):100-109.

Richey RC. Validating instructional design and development models. Innovations in instructional technology: Essays in honor of M.David Merrill. 2005:171-185.

Rindfleisch A. Customer co-creation: A typology and research agenda. . 2010.

Rindfleisch A. Customer co-creation: A typology and research agenda. . 2010.

Röpke J, Xia Y. The entrepreneurial university. Innovation, academic knowledge creation and regional development in a globalized economy.

Sander P, Stevenson K, King M, Coates D. University students' expectations of teaching. Studies in Higher Education. 2000;25(3):309-323.

Schimmel K, Eschenfelder M, Clark J, Marco G, Racic S. Differences in selection criteria among traditional students, adult continuing education students and graduate students. American Journal of Business Education (AJBE). 2011;2(5). 
Schoenfeld G, Bruce G. G, BRUCE G. School brand images and school choices in MBA programs. GMAC Research Reports. 2005.

Schools B. GMAC® 2010 global management education graduate survey. .

Schumpeter JA. The theory of economic development: An inquiry into profits, capital, credit, interest, and the business cycle. University of Illinois at UrbanaChampaign's Academy for Entrepreneurial Leadership Historical Research Reference in Entrepreneurship. 1934.

Schumpeter JA, Swedberg R. The economics and sociology of capitalism. Princeton University Press; 1991.

Simões C, Soares AM. Applying to higher education: Information sources and choice factors. Studies in Higher Education. 2010;35(4):371-389.

Sinkula JM. Market information processing and organizational learning. The Journal of Marketing. 1994:35-45.

Song $\mathrm{JH}$, Adams CR. Differentiation through customer involvement in production or delivery. Journal of Consumer Marketing. 1993;10(2):4-12.

Sturdy A, Morgan G. Segmenting the market: A review of marketing trends in french retail banking. International Journal of Bank Marketing. 1993;11(7):1119.

Sundbo J, Gallouj F. Innovation as a loosely coupled system in services. International Journal of Services Technology and Management. 2000;1(1):1536.

Taylor RE, Reed RR. Situational marketing: Application for higher education institutions. Journal of Marketing for HIGHER EDUCATION. 1995;6(1):23-36.

Temple P, Shattock M. What does" branding" mean in higher education? . 2007.

Toivonen M, Tuominen T. Emergence of innovations in services. The Service Industries Journal. 2009;29(7):887-902.

Tracey MW, Richey RC. ID model construction and validation: A multiple intelligences case. Educational Technology Research and Development. 2007;55(4):369-390.

Vargo SL, Lusch RF. Evolving to a new dominant logic for marketing. J Market. 2004:1-17.

Veloutsou C, Lewis JW, Paton RA. University selection: Information requirements and importance. International Journal of Educational Management. 2004;18(3):160-171. 
Venkatesh $U$. The importance of managing points-of-marketing in marketing higher education programmes-some conclusions. Journal of Services Research. 2001;1(1).

Voorhees RA. Institutional research and new program development. New Directions for Institutional Research. 2005;2005(128):29-39.

Voorhees RA. Institutional research and new program development. New Directions for Institutional Research. 2005;2005(128):29-39.

Witell L, Kristensson P, Gustafsson A, Löfgren M. Idea generation: Customer co-creation versus traditional market research techniques. Journal of Service Management. 2011;22(2):140-159.

Witell L, Kristensson P, Gustafsson A, Löfgren M. Idea generation: Customer co-creation versus traditional market research techniques. Journal of Service Management. 2011;22(2):140-159.

Zhang J, Zhang Z. On degree structure of american postgraduate education for professional degree and its enlightenment [J]. Journal of Higher Education. 2008;7:025.

Zhang $\mathrm{Y}$, Salaba A. What is next for functional requirements for bibliographic records? A delphi Study1. The Library. 2009;79(2). 


\section{CAPÍTULO 4}

METHODS AND TECHNIQUES FACILITATORS OF CO-CREATION INNOVATION IN MASTER PROGRAMS FOR POSTGRADUATE MARKET 


\section{Métodos y técnicas facilitadores de la co-creation innovation en programas máster para el mercado del posgrado}

Gabriela Ribes Giner. Universitat Politècnica de Valencia. Valencia, España Agustín Peralt Rillo. Universidad Europea de Valencia. Valencia, España.

\section{Resumen}

El objetivo del presente estudio es proponer métodos y técnicas para implementar con éxito un proyecto de innovación basado en el paradigma de la co-creation innovation para el mercado de los programas de máster. Con ello, se pretende facilitar a las universidades el camino hacia una política de innovación con éxito en su oferta formativa de los programas de máster, entendida como un binomio producto-servicio. Este proceso de innovación basada en la co-creación requiere una colaboración activa entre las distintas partes involucradas en este proceso: el estudiante adulto de posgrado, las empresas empleadoras y el personal de la universidad, que es la proveedora del servicio de formación. A través de una revisión de la literatura sobre las mejores prácticas de co-creation innovation en otros sectores, se han identificado los diferentes métodos y técnicas utilizados con buenos resultados. Además, se ha realizado una clasificación de los mismos, en función de las dimensiones conceptuales de la co-creation innovation. De esta manera, este estudio supone un avance más en la aplicación del modelo propuesto por Peralt y Ribes (2013) para potenciar la innovación basado en el paradigma de la co-creation innovation como posible estrategia de diferenciación para las universidades en el mercado del posgrado.

Palabras clave: innovación basada en la cocreación, orientación al consumidor, instituciones educativas, programas máster, métodos, procedimientos, técnicas 


\section{1. -Introducción}

Desde la adaptación de la educación al Espacio Europeo de Educación Superior (Real Decreto 1509/2005), las universidades españolas ofrecen dos tipos de máster para completar los estudios de grado: Título propio o Máster oficial. A partir de ese momento, al ya existente Máster Título propio de la universidad se le añadió la posibilidad de cursar el Máster oficial de Posgrado. Según afirman Lloret et al. (2007), el Máster oficial, al estar reglado, sigue un proceso de regulación con unos parámetros de calidad y certificación que hacen que cualquier proceso de cambio sea muy lento. Estos mismos autores también argumentan que el carácter gubernativo del Máster oficial hace que no puedan existir especializaciones avaladas por empresas. Por todo ello, el planteamiento de un proceso de co-creation innovation, que supone la involucración de agentes externos (clientes empresa y clientes estudiantes adultos) que no pertenecen a las instituciones educativas ni entidades reguladoras, resultará más conveniente para los Másteres Títulos propios y no para los Másteres oficiales.

Si nos centramos en la situación actual del mercado de los másteres*(en este trabajo, el concepto de máster hace referencia a un título académico que se obtiene al acabar un curso de posgrado con una duración de uno a tres años. Los términos máster y programa de posgrado serán utilizados indistintamente y con el mismo significado). Las instituciones educativas se enfrentan a una competencia cada vez mayor debido principalmente a la situación económica actual, la globalización de todos los sectores, incluido el educativo, y la introducción de programas educativos en línea en todo el mundo (Schimel et al., 2011). En la mayoría de las instituciones educativas, se invierten más recursos en el mantenimiento de la oferta actual de programas educativos que en el rediseño de los mismos o la creación de otros programas nuevos (innovación), con lo que se lograría de esta manera satisfacer mejor las necesidades del mercado (Voorhees, 2005).

Por todo ello, la innovación en los programas, como estrategia de diferenciación, es crucial en un momento complejo como el descrito en el mercado educativo de posgrado (Peralt y Ribes, 2013). Esta innovación puede focalizarse en elementos tangibles o intangibles, al entender la formación universitaria como un continuo de bienes y servicios donde algunos autores ya afirman que la simple combinación sinérgica de ellos puede ser fuente de ventaja competitiva para las universidades o instituciones educativas (Gallarza et al., 2008). Con respecto al tema de la innovación, varios estudios empíricos han demostrado que una involucración activa de los clientes en el proceso de innovación ejerce una influencia positiva en el éxito futuro de la misma (Gruner y Homburg, 2000; Kristensson et al., 2002). En esta misma dirección, Sjodin y Kristensson (2012) afirman que la involucración de los clientes como cocreadores está siendo considerada como una estrategia que mejora la tasa de éxito en innovaciones en servicios. Kristensson et al. (2008) señalaban que los consumidores pueden ser una fuente de ideas creativas vitales para una innovación con éxito.

En relación a este tipo de innovación y considerando la actitud de las organizaciones, el término open innovation (innovación abierta) se ha utilizado 
para caracterizar aquellas organizaciones en las que la innovación no se realiza exclusivamente con el personal interno de una empresa, sino de un modo cooperativo con otros actores externos (Chesbrough, 2003; Fredberg et al., 2008). En el mismo sentido, el término customer co-creation (co-creación centrada en el cliente) se introdujo para definir precisamente estas estrategias de open innovation que suponían la involucración activa de los clientes en este proceso (Piller, 2010). Son varios los autores que afirman en distintas publicaciones que la co-creación provoca efectos positivos en los resultados empresariales (Lusch y Vargo, 2006; Ballantyne y Barey, 2008).

Aunque el término co-creación no es nuevo (Prahalad y Ramaswamy, 2004; Oliveira y Von Hippel, 2011; Erikson et al., 2005), está recibiendo cada vez mayor atención tanto por parte de los académicos como de los profesionales (Lusch y Vargo, 2006; Martini et al., 2012). También se reconoce que esta área de conocimiento sobre la co-creación está en sus comienzos y que muchos aspectos de la misma todavía no se comprenden lo suficientemente bien (Hoyer et al., 2010).

El interés por el estudio de diferentes vías o caminos que faciliten la innovación en el mercado del posgrado tiene su justificación en esa necesidad por parte de las universidades de diseñar estrategias diferenciadoras en un entorno complejo y competitivo como el actual. La innovación basada en la cocreación aparece como una estrategia que puede facilitar el éxito en este proceso de innovación. En resumen, el objetivo principal de este trabajo es tratar de llenar el vacío en la literatura sobre la aplicación de la co-creation innovation en el mercado del posgrado identificando los diferentes métodos y técnicas utilizados con buenos resultados y realizando una clasificación de los mismos que facilite la elección del método más idóneo para el mercado de posgrado. En primer lugar, se analizará el marco teórico y se hará una breve revisión de la literatura sobre la co-creation innovation y distintos términos relacionados con la misma. Le seguirá una revisión y recopilación de los distintos métodos y técnicas utilizados en otros sectores para, finalmente, clasificarlos en función de las dimensiones conceptuales clave del concepto de co-creation innovation y analizar su futura aplicación en el sector educativo.

\section{Metodología.}

Se va a utilizar una revisión bibliográfica en profundidad. El primer propósito de esta revisión es enmarcar el problema que se quiere investigar, identificando conceptos relevantes e información que ayuden a completar este vacío en la literatura.

El proceso de revisión de la literatura es una herramienta clave utilizada para gestionar la diversidad de conocimientos para una investigación académica específica. Se considera que esta metodología es la correcta al tener en cuenta la afirmación de que una revisión ayuda a desarrollar un conocimiento confiable basado en la acumulación del mismo de varias fuentes (Tranfield et al., 2003). La revisión llevada a cabo es un proceso replicable, científico y transparente, o dicho en otras palabras, una tecnología que desea examinar las conclusiones, los procedimientos y las decisiones previas de los investigadores a través de la revisión de la literatura publicada o no publicada (Cook et al., 1995). El proceso de revisión ha sido desarrollado durante la 
última década y desempeña hoy en día un papel clave (Tranfield et al., 2003). En éste, se pretende completar las investigaciones existentes, proponiendo métodos y técnicas para la co-creation innovation para el caso concreto del mercado del posgrado, algo no tratado en el pasado por investigadores.

En el estudio se ha utilizado una variedad amplia de recursos bibliográficos: revistas y libros. Se han realizado búsquedas en las principales bases de datos del área de la gestión y la educación: WEB OF KNOLEDGE, ABI/INFORM, Emerald, ERIC, INGESTA. Estas búsquedas han llevado a consultar y seleccionar las principales revistas científicas: Studies in Higher Education, British Educational Research Journal, Handbook of service science, Research-technology management, Journal of Service Research, Review of Educational Research, Management \& Marketing, The Service Industries Journal, Academy of Management Review, International Journal of Educational Management, Research in Higher Education, Journal of the Academy of Marketing Science, European management journal, Journal of Higher Education Policy and Management, International Journal of Educational Management, Journal of Business Research, Marketing Science, Journal of International Marketing, Journal of Marketing for Higher Education, Strategy \& Leadership, American Educational Research Journal, MIT Sloan Management Review and International Journal of Services Technology and Management.

La búsqueda comienza con la identificación de palabras clave que se han obtenido del estudio, de la bibliografía y de las discusiones del equipo de revisión. Las palabras clave han sido: "customer co-creation innovation", "customer centricity", "educational institutions", "master", "posgraduate programs", "methods", "procedures" and "techniques". Para guardar las búsquedas se han utilizado bases de datos y para las citas de las referencias, se ha usado el programa RefWorks 2.0.

\section{Revisión de la literatura.}

3.1. Una orientación centrada en el consumidor y la consecuente oportunidad de co-creación para una innovación en los programas de máster

El desarrollo de una política de innovación centrada en el consumidor (usuario) puede desempeñar un papel clave en la aceleración de su proceso y llegar a ser una innovación más efectiva, al satisfacer las necesidades reales de los usuarios (Mulder y Stappers, 2009).

Sinkula (1994) define la «orientación centrada en el consumidor» como una orientación con un claro enfoque de aprendizaje que conduce a la innovación con éxito. Heiens (2000) sugiere que en la «orientación al mercado», las empresas deben tratar de comprender a los clientes y competidores incorporando ese conocimiento a los esfuerzos de planificación estratégica. Al mismo tiempo, en relación con la «orientación al mercado centrada en el consumidor», el término indica que la organización, en su conjunto, se ha comprometido a satisfacer las necesidades de todos los clientes importantes (Piller et al., 2011). Funciones tradicionalmente separadas como ventas, marketing y servicio al cliente se han integrado en una misma actividad que pretende estar realmente centrada en el cliente (Sheth y Sisodia, 
2006). En este tipo de empresa, es el cliente quien realmente dirige el negocio (Piller et al., 2011).

Son muchos y diversos los autores que relacionan este concepto de «orientación centrada en el consumidor» con la co-creation innovation. Von Hippel (2005) define la relación de esta «orientación centrada en el cliente» con la co-creation innovation como una integración activa de la participación del cliente en la innovación. Dahan y Hauser (2002) utilizan el concepto de «construir con los clientes», definiéndolo como una participación activa de los clientes en el diseño y desarrollo de futuras ofertas, a menudo a través de herramientas que son proporcionados por la empresa. Piller et al. (2011) describen el concepto de customer innovation co-creation como la aplicación de la gestión centrada en el cliente que utiliza e integra la información y las capacidades de los clientes y usuarios en el proceso de innovación. Sheth et al. (2000) afirman que esta «orientación centrada en el consumidor» llevará a que clientes y empresas creen de manera conjunta productos o servicios. Por otra parte, Prahalad y Ramaswamy (2004) introdujeron el concepto de co-creación como una forma única de creación de valor para los clientes, insistiendo en que esos mismos consumidores desean interactuar con las empresas y por lo tanto, crear valor con ellas. A su vez, Vargo y Lusch (2008) definen el concepto de co-creación como la forma en que las empresas tratan a sus clientes a través de la participación del cliente en la creación conjunta de valor.

En suma, la literatura existente pone de relieve claramente, a través de distintos autores, que la participación del cliente en actividades de co-creación durante el desarrollo de nuevos productos (innovación de producto) produce ideas que son más creativas y muy valoradas por los propios clientes (Bowonder et al., 2010; Kristensson et al., 2002; Nambisan y Baron, 2009; Prahalad y Ramaswany, 2003; Ramswamy y Gouillart, 2010). Así mismo, Kristensson et al. (2004) y Matthings et al. (2005) llegan a afirmar que esos clientes que se involucran en procesos de co-creación suelen aportar ideas más creativas que las de los propios desarrolladores internos de las empresas. En definitiva, esta involucración del consumidor en el proceso de desarrollo de nuevos productos puede mejorar la calidad del producto, reducir el riesgo e incrementar la aceptación por parte del mercado (Hoyer et Al, 2010).

En cuanto a los tipos de modelos de co-creación, Sanders y Stappers (2008) distinguen los siguientes, co-creación dentro de las distintas comunidades de consumidores, co-creación dentro de las mismas organizaciones y empresas, co-creación entre las empresas y el resto de implicados en el negocio, y por último la co-creación entre la empresa y sus clientes pudiendo distinguir entre clientes, consumidores o usuarios finales.

Considerando la clasificación de Sanders y Stappers (2008), el trabajo está centrado en la co-creación entre empresa y resto de implicados que son la institución educativa, la empresa empleadora y el estudiante adulto por la casuística del mercado del posgrado, donde el empleador también puede estar presente en el proceso de decisión del estudiante adulto a la hora de decidir realizar un máster.

Razón del caso concreto del sector educativo, las universidades emprendedoras alientan la colaboración entre académicos y empresarios para 
producir resultados notables en la innovación, invirtiendo más tiempo con los clientes en su contexto real (Gustafsson y Johnson, 2003; Goldstein y Thorp, 2010). En el mercado de la educación superior, Kotler y Fox (1995) propusieron que en este sector, era necesario considerar el enfoque de innovación en los productos teniendo en cuenta que debían satisfacer necesidades de dos segmentos diferentes: los estudiantes y los empleadores. En esa misma línea, Enache (2011) menciona que estos nuevos programas deben tener en cuenta no sólo las necesidades de los estudiantes, sino también las necesidades del mercado laboral. Es una opinión compartida que el sector tiene múltiples clientes, estudiantes, empleadores y la sociedad, principales beneficiarios de los servicios de posgrado (Maringe, 2006). Mientras que los estudiantes son los principales consumidores, los empleadores pueden ser vistos como consumidores secundarios o indirectos de los servicios de posgrado (Nicolescu et al., 2009).

Bajo esta filosofía de orientación al cliente, Voorhees (2005), en su investigación sobre el lanzamiento de programas educativos nuevos o la modificación de los programas actuales, destaca diferentes técnicas para evaluar el potencial de mercado de los nuevos programas: estudios basados en los futuros estudiantes, encuestas de los estudiantes actuales, segmentación de mercado, encuestas de empleo y estudios psicográficos de investigación.

Estudios recientes como el de Peralt y Ribes (2013), figura 1, han considerado que el concepto de innovación basada en la co-creación para programas de máster supone la participación activa y la interacción de los siguientes colectivos: los estudiantes adultos, los empleadores, los profesores y el resto de personal universitario. Estas prácticas pueden convertirse en algo vital para las instituciones en el mercado educativo, sin embargo esta participación de los consumidores en estos procesos es aún considerada como algo emergente, que carece de una estructura y un modelo de gestión claro, llegando a ser en la mayoría de los casos errática (Almirall y Wareham, 2008). El presente artículo está centrado precisamente en lo que otros denominan innovación, o participación del cliente en la co-creación desde la fase inicial del proceso de innovación, que es precisamente el aspecto menos investigado (Sjodin y Kristensson,2012). 


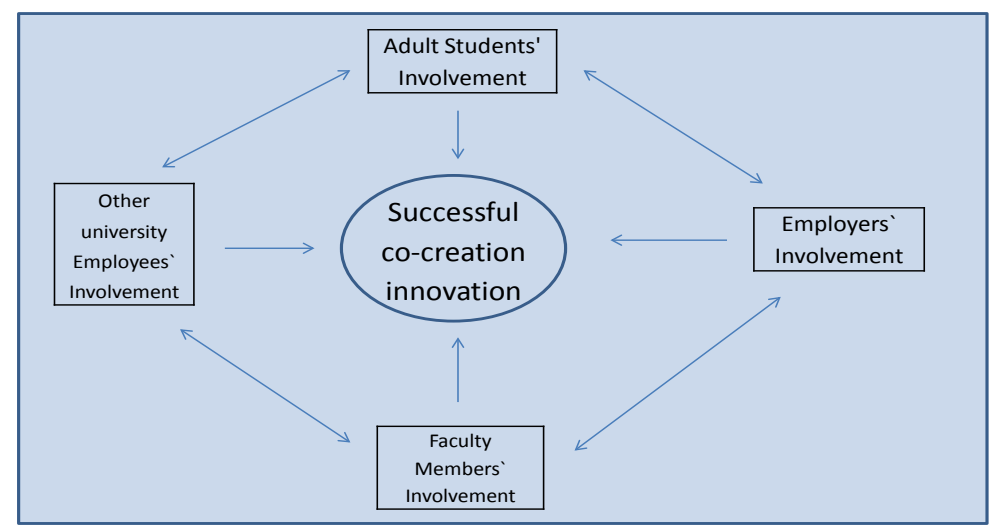

Figura 1 : Stakeholders involved in CO-CREATION Innovation for masters programs ( Ribes \& Peralt, 2013)

Figura 1: Actores involucrados en el proceso de innovación para programas másters ( Peralt y Ribes, 2013)

En la figura 1 se puede apreciar, implícitamente, el concepto de la lógica dominante del servicio (LDS) al considerar el valor de la red o network de los distintos colaboradores posibles (Nam y Lee, 2010). El valor de esa red reside en los diferentes recursos de los que disponen todos los participantes: proveedores, socios y clientes (Basole et al., 2008). Por lo tanto, esta LDS considera la innovación como una estrategia que requiere una serie de actividades (Yan et al, 2010) que promuevan el ejercicio de co-creación que implica un alto nivel de colaboración entre los distintos implicados en la cadena de valor, entre ellos el consumidor (Moeller, 2008). Estas actividades serán motivo de revisión en el siguiente apartado de esta investigación.

3.2. Identificación de los diferentes métodos y técnicas utilizados para los proyectos de co-creation innovation en otros sectores.

Payne et al. (2008) afirman que, a pesar de que existen diversas publicaciones con ejemplos de empresas que han llevado a cabo proyectos de co-creación, son muy escasas las que describen cómo se lleva a cabo ese proceso. En esta misma dirección apuntan Hoyer et al. ( 2010) cuando dicen que el área de la co-creación está en sus comienzos y que muchos aspectos todavía no se comprenden del todo.

Al mismo tiempo, en la revisión de la literatura existente se ha podido comprobar la insistencia por parte de diversos autores tanto en describir cómo se desea que sea la participación del consumidor en este proceso como en elegir el método o técnica más idónea para la puesta en práctica de este proceso, conceptos que lógicamente están ligados. 
En cuanto a la capacitación del consumidor, Vaisnore y Petraite (2012) señalan que el grado de participación del consumidor en este proceso de innovación deseado por parte de la empresa condicionará la necesidad de capacitarlo para participar a ese nivel deseado. Será la institución educativa quien tendrá que crear las condiciones previas para ello. En esta misma dirección, Prahalad y Rahamswamy (2004) concluyeron que los consumidores activos, informados y capacitados son los que co-crean valor de una manera incremental con la empresa. Por otra parte, Payne et al. (2008) afirman que la comunicación entre la empresa y el consumidor es vital para este proceso y debe ser, tal como indican Gustafsson et al. (2012), frecuente, bidireccional y no necesariamente física en todas las ocasiones, gracias a las oportunidades que ofrece Internet. Estos mismos autores proponen crear ese diálogo a través de Internet como si se tratara del propio entorno de consumo o prestación del servicio.

Por otra parte y con respecto a los posibles métodos o técnicas, se ha realizado un análisis sistemático de los que se han venido utilizando en la cocreation innovation, y se ha proporcionado una descripción de las mejores prácticas. El término «métodos y técnicas para la co-creation innovation» ha sido utilizado en muchos estudios (Sander y Stappers, 2008; Jaworski y Kohli, 2006; Bitner et al., 2008; y Witell et al., 2011). Lo definen como las distintas actividades donde los consumidores co-participaban junto con las empresas en el proceso de innovación.

En la tabla 2 se han identificado los distintos métodos y técnicas que se han utilizado con éxito en proyectos de co-creación. En la segunda columna aparecen señalados los principales autores que han realizado investigaciones basadas en estos métodos o técnicas. Por último, se presenta una descripción sobre los mismos así como ejemplos de sectores donde se han venido utilizando estas técnicas. Dentro de este proceso de revisión de los métodos y técnicas, se ha tenido en cuenta la disponibilidad de herramientas de la Web 2.0, ya que pueden acelerar la comunicación, el debate y el intercambio de información de modo que las experiencias locales de la persona o del equipo puedan ser compartidas por toda la organización (Stacey, 2003). Las distintas posibilidades que presenta el social media marketing permiten la interacción con los consumidores, donde las redes sociales se convierten en un lugar idóneo para que la empresa pueda recopilar información sobre los consumidores potenciales. 


\begin{tabular}{|c|c|c|c|}
\hline $\begin{array}{l}\text { Métodos y técnicas para } \\
\text { la co-creation innovation }\end{array}$ & Autores & Definición del Método o Técnica & Sector de aplicación \\
\hline Participatory Design & $\begin{array}{l}\text { Schuler y Namioka, 1993; Kensing, } \\
\text { F. 1998; Spinuzi } 2005\end{array}$ & $\begin{array}{c}\text { Se involucra activamente a todas las partes } \\
\text { interesadas (por ejemplo, empleados, socios, } \\
\text { clientes, ciudadanos, usuarios finales) en el proceso } \\
\text { de diseño con el fin de ayudar a asegurar que el } \\
\text { producto diseñado se ajuste a sus necesidades y } \\
\text { sea perfectamente utilizable }\end{array}$ & Servicios diseño arquitectónico \\
\hline Ehtnographic Fieldwork & $\begin{array}{l}\text { Bloomerg, 1995; Kensing y } \\
\text { Blomberg, 1998; Button, 2000; } \\
\text { Blomberg y Burrell, } 2009 .\end{array}$ & $\begin{array}{l}\text { Los investigadores y los diseñadores acuden a } \\
\text { lugares reales de trabajo o uso para comprender } \\
\text { mejor a las personas a través de observaciones y } \\
\text { entrevistas. En algunos proyectos, Design } \\
\text { Partipatory y Ethnographic fieldwork se combinan. }\end{array}$ & Maquinaria Industrial \\
\hline Lead users & $\begin{array}{l}\text { Von Hippel, 1999; Lillen et al, } \\
\text { 2002; Von Hippel, } 2005 .\end{array}$ & $\begin{array}{l}\text { Los lead users, usuarios avanzados con relación a la } \\
\text { población en la categoría de producto, son } \\
\text { consultados y aprovechados para fines de } \\
\text { prevesión de necesidades y generacion de nuevos } \\
\text { productos así como en las fases posteriores. }\end{array}$ & Salud y asistencia médica \\
\hline Empathic Design & $\begin{array}{l}\text { Leonard y Rayport, 1997, 2003; } \\
\text { Battarbee y Koskinene , 2005; } \\
\text { Steen et al, 2007. }\end{array}$ & $\begin{array}{c}\text { Los investigadores y diseñadores de la empresa } \\
\text { tratan de acercarse a los usuarios finales, viven y } \\
\text { trabajan tratando de empatizar con ellos, con su } \\
\text { experiencia y sus emociones }\end{array}$ & Material uso médico \\
\hline Co-Design & $\begin{array}{l}\text { Sanders, 2000,2002; Anderson- } \\
\text { Connell et al, 2002; Sanders y } \\
\text { Stappers 2008. }\end{array}$ & $\begin{array}{c}\text { Consiste en una actividad de co-creación } \\
\text { colaborativa en el desarrollo de producto y la fase } \\
\text { de prototipo, donde los profesionales del diseño y } \\
\text { de la investigación potencian, estimulan y guian a } \\
\text { los los clientes para lograr definir, configurar, un } \\
\text { producto o modificarlo en función de sus } \\
\text { necesidades. }\end{array}$ & Sector Turismo \\
\hline Presence Workshops & $\begin{array}{l}\text { Steen et al, 2007; Sleeswijh visser } \\
\text { et al, 2010; Greer y Lie, } 2012 .\end{array}$ & $\begin{array}{c}\text { Talleres presenciales donde el conocimiento de los } \\
\text { usuarios finales y los investigadores es compartido } \\
\text { para apoyar la inspiración, la empatía y el } \\
\text { compromiso con los usuarios finales. }\end{array}$ & Educación \\
\hline On-line Workshops & $\begin{array}{l}\text { Dede, 1996; Piller et al, 2005; } \\
\text { Folstad, } 2013 .\end{array}$ & $\begin{array}{l}\text { Talleres on-line en entornos virtuales multiusuario } \\
\text { en los que los participantes se convierten en } \\
\text { personas digitales dentro del mundo virtual } \\
\text { aportando ideas y opinando sobre las mismas. }\end{array}$ & Software \\
\hline Appreciative inquiry & $\begin{array}{l}\text { Whitney y Cooperrider, 2000; } \\
\text { Sullivan, 2004; Watkins et al, } 2013\end{array}$ & $\begin{array}{c}\text { Consiste en un método de investigación basado en } \\
\text { las mejores prácticas de una organización y la } \\
\text { investigación sobre ellas que se centra en lo que } \\
\text { podría ser posteriormente también un éxito de } \\
\text { futuro, "lo mejor de lo que es" y "lo que podría } \\
\text { ser". En ocasiones se involucra a proveedores y } \\
\text { clientes. }\end{array}$ & $\begin{array}{l}\text { Organizaciones sin ánimo de } \\
\text { lucro }\end{array}$ \\
\hline Contextual Design & $\begin{array}{l}\text { Beyer y Holzblatt, 1999; Holtzbatt, } \\
\text { K 2001; Steen et al, } 2007 .\end{array}$ & $\begin{array}{c}\text { Es una técnica que permite ayudar a los } \\
\text { investigadores y diseñadores a traves de la } \\
\text { observación de personas haciendo tareas en su } \\
\text { contexto natural para posteriormente luego aplicar } \\
\text { pragmáticamente sus resultados en el diseño de un } \\
\text { sistema o un producto. }\end{array}$ & Educación On-line \\
\hline Consumers Crowdsourcing & $\begin{array}{l}\text { Lakhani et al, 2010; Piller, 2010; } \\
\text { Bayus, 2011; Poetz y } \\
\text { Schreier,2009, } 2012 .\end{array}$ & $\begin{array}{c}\text { Se propone la generación de ideas a una población } \\
\text { potencialmente grande y desconocida, conocida } \\
\text { como la "multitud", a través de una convocatoria } \\
\text { abierta donde se ha dado un proceso de } \\
\text { autoselección entre los usuarios que deseen y } \\
\text { puedan responder a difundir ampliamente las } \\
\text { competencias de generación de ideas ( Piller y } \\
\text { Walcher 2006). }\end{array}$ & Publicidad \\
\hline Virtual Worlds & $\begin{array}{l}\text { Bonsu y Darmody, 2008; Fuller y } \\
\text { Matzler, 2007; Kholer et al, } 2009\end{array}$ & $\begin{array}{c}\text { Se crean mundos virtuales con experiencias } \\
\text { virtuales a través de las posibilidades del mundo } \\
2.0 \text { que se asemejen al máximo a la realidad. Se } \\
\text { crean plataformas virtuales alrededor de los } \\
\text { mismos con el objetivo de enganchar a los usuarios } \\
\text { del producto proporcionándoles una experiencia } \\
\text { única semejante a la real, que les haga participar y } \\
\text { proporcionar información sobre sus necesidades y } \\
\text { gustos a través de esta comunidad virtual que } \\
\text { busca representar un mundo real. }\end{array}$ & Diseño hogares \\
\hline Living Labs & $\begin{array}{c}\text { Abowd et al, 2000; Ballon et al, } \\
\text { 2005; Niitamo et al, 2006; Eriksson } \\
\text { et al, 2006; Bergvall-Karebon et al, } \\
2009\end{array}$ & \begin{tabular}{|} 
Se define como un ecosistema real de open \\
innovation muy centrado en el consumidor, en un \\
entorno de la vida real, donde los usuarios y los \\
prestadores del servicio son motivados a colaborar \\
entre ellos en esos entornos reales para co-crear \\
innovaciones.
\end{tabular} & Servicios campus universitarios \\
\hline
\end{tabular}

Tabla 1: Selección de métodos y técnicas para la co-creación. Fuente: elaboración propia 


\section{Resultados. Clasificación de los métodos y técnicas para la co-creation innovation en el mercado del posgrado}

Para la clasificación de los distintos métodos y técnicas reunidos y expuestos en el epígrafe anterior, se han seguido las dimensiones conceptuales señaladas por Diener y Piller (2010) en un proceso de cocreation:

1.- La etapa en el proceso de la innovación en la que los actores externos participan: a) fase inicial de agrupación de posibles ideas; b) concepción o desarrollo donde trasforman esas ideas en prototipos o ideas de servicio; c) desarrollo y prueba de mercado (Vaisnore y Petraite, 2012).

2.- El grado de libertad que se les otorga a los actores externos o la autonomía que se le da al cliente en este proceso.

3.- El grado de colaboración entre los distintos actores teniendo en cuenta la estructura de las relaciones subyacentes (cada grupo exclusivamente entre sí o relaciones multilaterales entre los distintos grupos). Pinegar (2000) lo define como las interacciones que se dan entre los distintos participantes, que pueden ir de simple trasferencia de información en forma de sugerencias hasta transacciones de conocimientos complejos donde, en estos últimos casos, los consumidores adoptan un papel activo y contribuyen en el proceso intelectual, físico o económico. Este nivel de interacciones estará directamente relacionado con los términos utilizados por Vahaverbeke et al, (2008) en cuanto a la exposición por parte de la empresa a los agentes externos en relación a la estrategia de innovación de la compañía. Cuanto mayores sean las nuevas prácticas derivadas de una adaptación cultural y cuanto mayor sea la adaptación de la estructura interna a estas nuevas relaciones con agentes externos, mayores serán las interacciones y la transferencia de conocimiento (Chesbrough et al., 2006).

Con estos cambios culturales y organizativos se pretende desarrollar la capacidad de integrar el conocimiento de los agentes externos que Belkahala y Triki (2011) definen como las capacidades que la empresa desarrolla para integrar al consumidor y crear valor de manera conjunta en el proceso de innovación. En este sentido, Foss et al. (2011) también insisten en la importancia no sólo de integrar sino de explotar y trabajar ese conocimiento transfiriéndolo dentro de los distintos departamentos de la organización. Una forma de compartir internamente ese conocimiento es a través de la Intranet a la que todos suelen tener acceso, lo que ayuda a lograr un mayor éxito con el proyecto (Vaisnore y Petraite, 2012). Al mismo tiempo, Vaisnore y Petraite (2012) señalan que la capacitación del consumidor en estos procesos consiste en una serie de condiciones previas, herramientas y prácticas que la empresa crea o utiliza para facilitar la involucración del consumidor como socios externos para la innovación.

La clasificación se ha realizado teniendo en cuenta la literatura revisada y las características propias del mercado del posgrado y del sector de las instituciones universitarias (tabla 2). Entre estas características se ha considerado la existencia de dos objetivos, los estudiantes adultos y las 
empresas empleadoras así como el tipo de compra implicante que supone la decisión de realizar un posgrado.

\begin{tabular}{|c|c|c|c|c|}
\hline \multirow{2}{*}{$\begin{array}{l}\text { Métodos y técnicas } \\
\text { para la co-creation } \\
\text { innovation }\end{array}$} & \multirow{2}{*}{$\begin{array}{l}1^{a} \text { Fase: CONCEPCIÓN } \\
\text { Agrupación de Ideas- } \\
\text { Concepción Idea }\end{array}$} & \multirow{2}{*}{$\begin{array}{c}2^{\mathrm{a}} \text { Fase: DESARROLLO y PRUEBA } \\
\text { Desarrollo y prueba de } \\
\text { mercado de la idea elegida }\end{array}$} & \multicolumn{2}{|c|}{ LIBERTAD ACTUACIÓN CO-PARTICIPACIÓN } \\
\hline & & & $\begin{array}{l}\text { Grado de libertad } \\
\text { de los agentes } \\
\text { exernos/clientes }\end{array}$ & Grado de colaboración \\
\hline Participatory Design & & & Alta & Baja \\
\hline Ehtnographic Fieldwork & & & Alta & Baja \\
\hline Lead users & & & Medio & Medio \\
\hline Empathic Design & & & Medio & Medio \\
\hline Co-Design & & & Medio & Medio \\
\hline Presence Workshops & & & Medio & Medio \\
\hline On-line Workshops & & & Alto & Bajo \\
\hline Appreciative inquiry & & & Medio & Medio \\
\hline Contextual Design & & & Baja & Baja \\
\hline $\begin{array}{l}\text { Consumers } \\
\text { Crowdsourcing }\end{array}$ & & & Alta & Baja \\
\hline Virtual Worlds & & & Alta & Baja \\
\hline Living Labs & & & Alta & Alta \\
\hline
\end{tabular}

Tabla 2: Clasificación de los métodos y técnicas para la co-creation para programas de máster según las dimensiones conceptuales de Diener y Piller (2010). Fuente: elaboración propia.

Una vez realizada esta clasificación, y considerados los distintos sectores donde se ha aplicado cada uno de los métodos a través de la literatura revisada, se puede proponer el living lab como la técnica de co-creación más adecuada dado que, se aplica tanto a la fase de concepción como a la de desarrollo y prueba de mercado. Además, cuenta con un grado de libertad alto, para los agentes externos y al mismo tiempo, un alto grado de colaboración. En futuras investigaciones se analizará, con más profundidad, su idoneidad para nuestro mercado de posgrado.

Comparten esta propuesta diversos autores. Folstad (2013) defiende que el living lab es una técnica capacitada para representar entornos de consumo de servicios con alta implicación de los usuarios y con gran uso de infraestructuras físicas; concuerda con el concepto de prestación de un servicio de posgrado universitario. También, hay experiencias previas que la validan en sectores como hospitales, residencias para estudiantes, aeropuertos e incluso campus universitarios (Guldemond y Geenhuizen, 2012). Cabe destacar el living lab realizado sobre servicios y formas de organización en el Hospital Universitario de Herlev (Guldemond y Geenhuizen, 2012), como posible puesta en práctica con información para la casuística de las instituciones educativas.

Sobre esta experiencia, Guldemon y Geenhuizen (2012) recalcan varios puntos que merecen consideración (algunos ya se han señalado en apartados anteriores): 1. Necesidad de una interrelación intensiva entre los actores participantes. 2. Es necesaria la figura de un agente externo integrador del resto. 3. La importancia de las herramientas tecnológicas para facilitar la comunicación y el tratamiento de la información. 4. Debería evitarse el papel dominante de algunos de los actores participantes sobre los demás. Sin embargo, estos mismos autores (señalan que no existe suficiente experiencia con los living labs en casos reales como para realizar una revisión más exhaustiva y sistemática del concepto, por lo que representa una invitación para futuras investigaciones. 
Asimismo Folstad (2013) apuesta por el living lab, aunque apunta que después se debe considerar el resto de técnicas y elegir la más idónea que se desarrollará dentro de ese living lab, según los objetivos de la innovación y los distintos factores del proyecto que puedan influir. Dentro de esta corriente, diversos autores (Eriksson et al., 2006; Loh, 2008; Almirall, 2008; Dimitri y De Marez, 2010) consideran muy útil la combinación del living Lab con los lead users con el objetivo de la co-creación.

\section{Conclusiones y futuras orientaciones a la investigación}

El sector educativo de posgrado se encuentra en un momento complejo con una clara necesidad de identificar y plantear estrategias diferenciadoras. La innovación, como forma de diferenciarse, puede ser clave en ese intento estratégico. Dentro de este proceso de innovación, la consideración de paradigmas novedosos utilizados en otros sectores, como es el caso de la cocreation innovation, puede ayudar en gran medida a que esta innovación se lleve a cabo con éxito y sea realmente la que marque la diferencia en el posgrado. Dentro de esta innovación basada en la co-creación, resulta necesario profundizar cómo llevar a cabo este proceso, analizar qué métodos y técnicas se pueden plantear e incluso clasificarlas teniendo en cuenta el tipo de proceso que se pretende.

La consideración de los factores clave en un proceso de co-creación para las instituciones educativas en su política de innovación de programas de máster y la consecuente búsqueda de los métodos y técnicas más idóneas para el mismo según las experiencias en otros sectores, es el motivo del presente artículo.

Del marco teórico y de las propuestas realizadas en este artículo, se extraen las siguientes conclusiones que se apuntan como orientaciones para los órganos de gestión de las universidades, así como para futuras investigaciones posibles:

- El proceso de co-creation innovation que ha funcionado con éxito en otros sectores debería ser considerado en el sector educativo donde estarían involucrados el empleador, el estudiante adulto (estos dos como generadores de ideas y trabajando de manera interrelacionada), y el personal de las instituciones educativas. Las instituciones educativas que decidan comenzar un proyecto de co-creación deberán reflexionar sobre las consecuencias de un proceso de este tipo, en cuanto a la apertura que supone al exterior de cierta información confidencial interna así como la disposición que deben tener para modificar políticas internas en función de las propuestas de los agentes externos.

- Poner en marcha un proceso de co-creación de esta envergadura con una involucración tan alta del consumidor requiere un gran dominio del proceso. En esta línea y considerando las aportaciones de Hoyer et al. (2010) resultará de suma importancia considerar los elementos motivadores con los estudiantes adultos y los empleadores para lograr su involucración. Teniendo en cuenta que el realizar un posgrado puede que sea un servicio que se consume una única vez por parte del profesional adulto, a la hora de elegir los participantes se debería considerar la conveniencia de que sean antiguos alumnos 
(considerados, en cierta manera, «lead users»), alumnos actuales o futuros alumnos. Y para las empresas o empleadores, también se debería considerar la conveniencia de que sean empresas en las que algunos de sus empleados ya han optado a estos programas de máster.

- Esta investigación se ha centrado en plantear los distintos métodos y técnicas posibles de entre los existentes para posteriormente clasificarlos según las distintas dimensiones conceptuales planteadas. Con ello se ha pretendido minimizar las probabilidades de fracaso a la hora de implementar por parte de las instituciones educativas el método que mejor se adapte a los objetivos de co-creation innovation que se planteen para poder alcanzarlos. Aquellos métodos y técnicas que faciliten el trabajo e interacción de este proceso en entornos reales de consumo pueden ser muy beneficiosos como señalan Witell et al. (2010).

- De la clasificación planteada, de los métodos señalados es precisamente el living lab el que mejor representa ese proceso de trabajar la co-creación en situaciones y entornos reales de trabajo, tal y como apuntan algunas investigaciones (Eriksson et al., 2005; Loh, 2008; Almirall, 2008; Dimitri y De Marez, 2010). Al mismo tiempo, dada la particularidad del proceso de compra de un máter, consideramos que la involucración de Lead Users es algo también a considerar. Se invita a las instituciones educativas a plantear dinámicas de este tipo por la fortaleza que puede suponer la combinación de estas dos técnicas en un proceso de co-creación.

Por último, asumiendo las limitaciones de este trabajo, en próximas investigaciones se propone ofrecer avances y determinar exactamente el método o técnica más idónea para llevar a cabo esta co-creation innovation en programas de máster según los objetivos concretos del proyecto, prestando una especial atención a la combinación del living lab y lead users. Al mismo tiempo, cabe señalar que en cuanto a la elección del gestor o coordinador del proyecto, se debe tener en cuenta que las universidades suelen participar en los procesos de innovación en calidad de expertos para ayudar o para actuar como intermediarios entre los distintos sectores y empresas. Sin embargo, en nuestra investigación, el personal universitario forma parte de los actores involucrados en el proceso de co-creación, por lo que el éxito de la innovación redunda en su propio beneficio. Por tanto, será necesario abordar la conveniencia de que la figura del intermediario sea alguien distinto al personal de las universidades, como por ejemplo, tal como señalan Bergvall-Kareborn et al. (2009), consultores externos o investigadores ajenos. 


\section{6.-Referencias}

Abowd GD. Classroom (2000): An experiment with the instrumentation of a living educational environment. IBM Syst J. 38(4):508-530

Almirall E (2008) The IT role in innovation.

Almirall E, Wareham J (2008) Living labs and open innovation: Roles and applicability. The Electronic Journal for Virtual Organizations and Networks;10(3):21-46.

Anderson-Connell, L. J., Ulrich, P. V., \& Brannon, E. L. (2002). A consumerdriven model for mass customization in the apparel market. Journal of Fashion Marketing and Management, 6(3), 240-258.

Ballantyne D, Varey RJ (2008)The service-dominant logic and the future of marketing. Journal of the Academy of Marketing Science. ;36(1):11-14.

Ballon P, Pierson J, Delaere S (2005). Test and experimentation platforms for broadband innovation: Examining european practice:4-6.

Basole, R. C., Rouse, W. B., McGinnis, L. F., Bodner, D. A., \& Kessler, W. C. (2011). Models of complex enterprise networks. Journal of Enterprise Transformation, 1(3), 208-230.

Battarbee, K., \& Koskinen, I. (2005). Co-experience: user experience as interaction. CoDesign, 1(1), 5-18.

Bayus BL. (2011). Crowdsourcing new product ideas over time. University of North Carolina.

Belkahla, W., \& Triki, A. (2011). Customer knowledge enabled innovation capability: proposing a measurement scale. Journal of Knowledge Management, 15(4), 648-674.

Bergvall-Kåreborn B, Ihlström Eriksson C, Ståhlbröst A, Svensson J (2009)A milieu for innovation-defining living labs.

Beyer H, Holtzblatt K (1999) Contextual design. interactions;6(1):32-42.

Bitner MJ, Ostrom AL, Morgan FN (2008). Service blueprinting: A practical technique for service innovation. Calif Manage Rev;50(3):66

Blomberg, J., \& Burrell, M. (2009). An ethnographic approach to design. Human-computer interaction: Development process, 71-94.

Bitner, M. J., Ostrom, A. L., \& Morgan, F. N. (2008). Service blueprinting: a practical technique for service innovation. California Management Review, 50(3), 66.

Bloomberg, J. L. (1995). Ethnography: Aligning field studies of work and design. Perspectives on HCl: Diverse Approaches. Academic Press, London, 175-197. 
Bødker, M., \& Langgaardsvej, R. (2004). Position Paper for the Aesthetic $\mathrm{HCl}$ Workshop. Aesthetic Approaches to Human-Computer Interaction, 5.

Bonsu, S. K., \& Darmody, A. (2008). Co-creating Second Life MarketConsumer Cooperation in Contemporary Economy. Journal of Macromarketing, 28(4), 355-368.

Bowonder B, Dambal A, Kumar S, Shirodkar A (2010). Innovation strategies for creating competitive advantage. Research-technology management. ;53(3):1932.

Button, G. (2000). The ethnographic tradition and design. Design studies, 21(4), 319-332.

Chesbrough HW. (2003). Open innovation: The new imperative for creating and profiting from technology. Harvard Business Press.

Chesbrough, H., Vanhaverbeke, W., \& West, J. (2006). Open innovation: a new paradigm for understanding industrial innovation. Open innovation: researching a new paradigm, 1-12.

Cook, D. J., Sackett, D. L., \& Spitzer, W. O. (1995). Methodologic guidelines for systematic reviews of randomized control trials in health care from the Potsdam Consultation on Meta-Analysis. Journal of clinical epidemiology, 48(1), 167-171.

Crabtree, A., Rodden, T., Tolmie, P., \& Button, G. (2009, April). Ethnography considered harmful. In Proceedings of the SIGCHI Conference on Human Factors in Computing Systems (pp. 879-888). ACM.

Dahan E, Hauser JR (2002). Product development: Managing a dispersed process. Handbook of marketing. :179-222.

Dede C (1996). The evolution of distance education: Emerging technologies and distributed learning. American Journal of Distance Education. ;10(2):4-36.

Diener K, Piller F. The market for open innovation (2010). First study to compare the offerings, methods, and competences of intermediaries, consultancies, and brokers for open innovation. RWTH-TIM Group. .

Enache I (2011). Marketing higher education using the 7 ps framework. Bulletin of the Transilvania University of Braşov• Vol. ;4(53).

Eriksson M, Niitamo V, Kulkki S, Hribernik KA (2006). Living labs as a multicontextual R\&D methodology. :26-28.

Eriksson M, Niitamo V, Kulkki S (2005). State-of-the-art in utilizing living labs approach to user-centric ICT innovation-a european approach. Lulea: Center for Distance-spanning Technology. Lulea University of Technology Sweden.

Folstad A. A (2013). Guide to online applications for user involvement in living lab innovation. Information Systems and Technology for Organizations in a Networked Society:34. 
Foss, N. J., Laursen, K., \& Pedersen, T. (2011). Linking customer interaction and innovation: The mediating role of new organizational practices. Organization Science, 22(4), 980-999.

Fredberg T, Elmquist M, Ollila S (2008). Managing open InnovationPresent findings and future directions. . 2008.

Füller, J., \& Matzler, K. (2007). Virtual product experience and customer participation-A chance for customer-centred, really new products. Technovation, 27(6), 378-387.

Gallarza MG, Fayos T, Servera D, Arteaga F, Francés DS (2008). Análisis y evaluación del servicio de formación universitaria: Implicaciones para el marketing estratégico de las universidades.

Goldstein B, Thorp HH (2010). Engines of innovation: The entrepreneurial university in the twenty-first century. Univ of North Carolina Press

Greer CR, Lei D (2012). Collaborative innovation with customers: A review of the literature and suggestions for future research. International Journal of Management Reviews;14(1):63-84.

Gruner KE, Homburg C (2000). Does customer interaction enhance new product success? Journal of business research. ;49(1):1-14.

Guldemond, N., \& van Geenhuizen, M. (2012). 'Livings Labs' for New Health Concepts and Medical Technology in Cluster Development.

Gustafsson E, Jonsson A (2003). Always best connected. Wireless Communications, IEEE;10(1):49-55.

Gustafsson, A., Kristensson, P., \& Witell, L. (2012). Customer co-creation in service innovation: a matter of communication?. Journal of Service Management, 23(3), 311-327.

Heiens RA (2000) Market orientation: Toward an integrated framework. Academy of Marketing Science Review. ;1(1):1-4.

Hennig-Thurau, T., Gwinner, K. P., Walsh, G., \& Gremler, D. D. (2004). Electronic word-of-mouth via consumer-opinion platforms: what motivates consumers to articulate themselves on the internet?. Journal of interactive marketing, 18(1), 38-52.

Holtzblatt K (2001). Contextual design: Experience in real life. In: Mensch \& computer. . Springer; 19-22.

Hoyer, W. D., Chandy, R., Dorotic, M., Krafft, M., \& Singh, S. S. (2010). Consumer cocreation in new product development. Journal of Service Research, 13(3), 283-296.

Howe J (2006). The rise of crowdsourcing. Wired magazine. ;14(6):1-4. 1

Jaworski B, Kohli AK (2006). Co-creating the voice of the customer. The Service-dominant Logic of Marketing: Dialog, debate, and directions:109-117. 
Kensing, F., \& Blomberg, J. (1998). Participatory design: Issues and concerns. Computer Supported Cooperative Work (CSCW), 7(3-4), 167-185.

Kohler T, Matzler K, Füller J (2009). Avatar-based innovation: Using virtual worlds for real-world innovation. Technovation;29(6):395-407.

Kotler P, Fox KF (1995). Strategic marketing for educational institutions. .

Kristensson P, Magnusson PR, Matthing J (2002). Users as a hidden resource for creativity: Findings from an experimental study on user involvement. Creativity and innovation management;11(1):55-61.

Kristensson, P., Matthing, J., \& Johansson, N. (2008). Key strategies for the successful involvement of customers in the co-creation of new technologybased services. International Journal of Service Industry Management, 19(4), 474-491.

Lakhani, K., Garvin, D., \& Lonstein, E. (2010). Topcoder (a): Developing software through crowdsourcing. Harvard Business School General Management Unit case, (610-032).

Leonard, D., \& Rayport, J. F. (1997). Spark innovation through empathic design. Harvard business review, 75, 102-115.

Leonard D, Rayport JF (2003). Spark innovation through empathic design. Harv Bus Rev. 199755. Lincoln YS. Constructivist knowing, participatory ethics and responsive evaluation: A model for the 21st century. Springer.

Lloret, J., Lloret, A. T., \& Lloret, G. (2007). ¿ Másters Oficiales de Postgrado o Másters Títulos Propios de las Universidades?. In $\vee$ Jornades de Xarxes $\mathrm{d}_{i}$ Investigació en Docència Universitària [Recurso electrónico]: V Jornadas de Redes de Investigación en Docencia Universitaria. (p. 18).

Löh, H. (2008). How to drive innovation in CWE-A Living Lab Approach.

Lusch RF, Vargo SL (2006) Service-dominant logic: Reactions, reflections and refinements. Marketing theory ;6(3):281-288

Maringe F (2006). University and course choice: Implications for positioning, recruitment and marketing. International Journal of Educational Management. ;20(6):466-479.

Martini A, Gastaldi L, Corso M, Magnusson M, Laugen BT. (2012). Continuously innovating the study of continuous innovation: From actionable knowledge to universal theory in continuous innovation research. Int $\mathrm{J}$ Technol Manage;60(3):157-178.

Moeller S (2008). Customer integration-A key to an implementation perspective of service provision. Journal of Service Research;11(2):197-210.

Mulder I, Stappers PJ (2009). Co-creating in practice: Results and challenges. .

Nam K, Lee NH (2010). Typology of service innovation from service-dominant logic perspective. Journal of Universal Computer Science;16(13):1761-1775. 
Nambisan S, Baron RA (2009). Virtual customer environments: Testing a model of voluntary participation in value Co Manage;26(4):388-406.

Nicolescu L, Pricopie R, Popescu A (2009). Country differences in the internationalization of higher Education-How can countries lagging behind diminish the gap. Review of International Comparative Management;10(5).

Niitamo V, Kulkki S, Eriksson M, Hribernik KA (2006). State-of-the-art and good practice in the field of living labs:26-28.

Oliveira P, von Hippel E (2011). Users as service innovators: The case of banking services. Research Policy;40(6):806-818.

Payne, A. F., Storbacka, K., \& Frow, P. (2008). Managing the co-creation of value. Journal of the Academy of Marketing Science, 36(1), 83-96.

Peralt, A., \& Ribes, G. (2013). A proactive market orientation for the postgraduate programs. Dirección y Organización, (50), 37-47.

Piller, F. (2010). Open innovation with customers: crowdsourcing and cocreation at Threadless. Available at SSRN 1688018.

Piller F, Ihl C, Vossen A (2011). Customer co-creation: Open innovation with customers. Wittke, V. /Hanekop, H:31-63.

Piller F, Schubert P, Koch M, Möslein K (2005). Overcoming mass confusion: Collaborative customer Co-Design in online communities. Journal of Computer Mediated Communication. ;10(4):00-00.

Pinegar, J. S. (2000). Customer Involvement in Industrial Product Development: Creating Superior Products.

Poetz, M. K., \& Schreier, M. (2012). The value of crowdsourcing: can users really compete with professionals in generating new product ideas?. Journal of Product Innovation Management, 29(2), 245-256.

Poetz MK, Schreier M (2009). The value of crowdsourcing. Can Users Really Compete with Professionals in Generating New Product Ideas.

Prahalad CK, Ramaswamy V (2004). Co-creating unique value with customers. Strategy \& Leadership;32(3):4-9.

Prahalad CK, Ramaswamy V (2003). The new frontier of experience innovation. MIT Sloan Management Review;44(4):12-18.

Ramaswamy, V., \& Gouillart, F. J. (2010). The power of co-creation: Build it with them to boost growth, productivity, and profits. SimonandSchuster. com.

Real Decreto 1509/2005 (16 de diciembre). Estructura de las enseñanzas universitarias y se regulan los estudios universitarios oficiales de grado

Sanders E (2000). Generative tools for co-designing. In: Collaborative design. Springer;:3-12 
Sanders EB (2002). From user-centered to participatory design approaches. Design and the social sciences: Making connections:1-8.

Sanders EB, Stappers PJ (2008). Co-creation and the new landscapes of design. Co-design. ;4(1):5-18.

Schimmel K, Eschenfelder M, Clark J, Marco G, Racic S (2011) Differences in selection criteria among traditional students, adult continuing education students and graduate students. American Journal of Business Education (AJBE);2(5).

Schuler D, Namioka A (1993). Participatory design: Principles and practices. CRC PressI LIC.

Sheth, J. N., Sisodia, R. S., \& Barbulescu, A. (2006). The image of marketing. Does Marketing Need Reform, 26-36.

Sheth, J. N., Sisodia, R. S., \& Sharma, A. (2000). The antecedents and consequences of customer-centric marketing. Journal of the Academy of Marketing Science, 28(1), 55-66.

Sinkula, J. M. (1994). Market information processing and organizational learning. The Journal of Marketing, 35-45.

Sjödin, C., \& Kristensson, P. (2012). Customers' experiences of co-creation during service innovation. International Journal of Quality and Service Sciences, 4(2), 189-204.

Sleeswijk Visser, F., Van der Lugt, R., \& Stappers, P. J. (2007). Sharing user experiences in the product innovation process: Participatory design needs participatory communication. Creativity and innovation management, 16(1), 3545.

Spinuzzi, C. (2005). The methodology of participatory design. Technical Communication, 52(2), 163-174.

Stacey R (2003). Learning as an activity of interdependent people. Learning Organization, The. 2003;10(6):325-331.

Steen M, Kuijt-Evers L, Klok J (2007). Early user involvement in research and design projects-A review of methods and practices.

Sullivan, M. (2004). The promise of Appreciative Inquiry in library organizations. Library Trends, 53(1), 218-229.

Tranfield, D., Denyer, D., \& Smart, P. (2003). Towards a methodology for developing evidence systematic review. British journal of management, 14(3), 207-222.

Vaisnore, A., \& Petraite, M. (2012). The enablement of customer's participation in the open innovation processes: an analytical framework. Economics and Management .17(4), 1600-1612. 
Vanhaverbeke, W., Van de Vrande, V., \& Cloodt, M. (2008). Connecting absorptive capacity and open innovation. Available at SSRN 1091265.

Vargo SL, Lusch RF (2008). Service-dominant logic: Continuing the evolution. Journal of the Academy of Marketing Science;36(1):1-10.

Von Hippel E (2005). Democratizing innovation: The evolving phenomenon of user innovation. Journal für Betriebswirtschaft. 2005;55(1):63-78.

Voorhees RA (2005). Institutional research and new program development. New Directions for Institutional Research;(128):29-39.

Watkins JM, Mohr BJ, Kelly R (2013)Appreciative inquiry: Change at the speed of imagination. Vol 35.

Whitney D, Cooperrider DL (2000) The appreciative inquiry summit: An emerging methodology for whole system positive change. OD PRACTITIONER.

Witell, L., Kristensson, P., Gustafsson, A., \& Löfgren, M. (2011). Idea generation: customer co-creation versus traditional market research techniques. Journal of Service Management, 22(2), 140-159.

Yan, J., Ye, K., Wang, H., \& Hua, Z. (2010). Ontology of collaborative manufacturing: Alignment of service-oriented framework with service-dominant logic. Expert Systems with Applications, 37(3), 2222-2231. 


\section{CAPÍTULO 5}

STRUCTURAL EQUATION MODELING OF CO-CREATION AND ITS INFLUENCE ON THE STUDENT'S SATISFACTION AND LOYALTY TOWARDS UNIVERSITY 


\title{
Structural equation modeling of co-creation and its influence on the student's satisfaction and loyalty towards university
}

\author{
Gabriela Ribes Giner (gabrigi@omp.upv.es) \\ Universidad Politécnica of Valencia( UPV) \\ Agustín Peralt Rillo (agustin.peralt@uem.es). \\ Universidad Europea of Valencia \\ Department of Business Management
}

\begin{abstract}
This article aims to measure empirically the impact of co-creation on the key marketing outcomes of student satisfaction, and the consequent loyalty induced, taking as reference the results obtained with a questionnaire used during class time among postgraduate students at Spanish universities.

Our research is an approach to educational institutions' marketing strategy with causal methodology, and, for that purpose, SEM methodology is used, from a conceptual research model with some hypothesised relations based on an indepth literature review, confirming some concepts such as the influence of cocreation on key marketing outcomes and the importance of co-creation for marketing policies for Educational Institutions.
\end{abstract}

Keywords: Co-creation, satisfaction, loyalty, SEM, students, universities. 


\section{1.-Introduction}

The current global and highly competitive environment among universities is driving their need to develop unique marketing strategies with a "greater focus on the student" to help stand out among them. $(1,2,3,4)$. Thus, there is a need among universities to understand the factors that contribute to greater mastery and understanding of what influences student perceptions about the service they receive and, thus, be able to influence and achieve better experiences and higher loyalty rates among students (5). Helgesen(6) points out that student retention has become as important as attracting them.

Similarly, within this concept of "greater focus on the consumer," the concept of co-creation appears as an emerging concept that has many opportunities, as it is considered a potential source of competitive advantage for companies or institutions (7,8,9). Mathis (10) notes that co-creation is a relatively new research concept with many possibilities to expand. . In this regard, Carvalho and De Oliveira Mota(11) note that the student-teacher cocreation process directly contributes to the perception of value by the student. Furthermore, the Fraunhofer Institute, in its recent research, points out that universities are not benefiting enough from the great potential of co-creation and from the possibility of involving students on a day to day basis in order to contribute to the improvement. Ribes and Peralt $(12,13)$ highlight, in their recent publications, the importance that the concept of co-creation can have on education as it may be a unique competitive strategy.

Finally, Diez-Mendez and Gummenson(14) note that universities should make a change in perspective: from serving education to students to actually co-create it with them by creating the education service with their active participation. The aim of this article is to what extent co-creation ( the student works together with the University in order to add value to the educational service) contributes to loyalty and satisfaction levels.

\section{2.- Background, hypotheses and conceptual model}

The aim of this section is, through a literature review, to consider possible relationships between co-creation and marketing outputs in order to suggest a model to be later validated that responds to the issues raised by Rajah et al (15).

\subsection{Co-creation and Satisfaction}

In education, student satisfaction is defined as the subjective assessment carried out by the student him/herself of his/her experiences and results with education and student life (16). Along the same lines, Ledden et al (17) point out that to achieve high levels of satisfaction among students, one must be able to understand their needs and provide them with superior value. In reviewing the literature, several authors stress the positive and direct relationship between co-creation and satisfaction $(18,19,20)$. 


\subsection{Satisfaction and Loyalty}

As a result of increased competition between educational institutions, many authors have focused on the study of student loyalty $(11,21,22)$. In the specific case of the education sector, the literature furthers the concept by referring to student loyalty as long-lasting even after having completed their studies. Thus, subsequent behavioural patterns by students include donations, alumni membership and social participation and positive recommendations of the same (23).

In the education market, several studies stress the positive relationship between satisfaction and loyalty of the student $(24,23,25)$.

\subsection{Co-creation and Loyalty}

Zhang (26) defines loyalty as commitment from consumers making repeat purchases from the same company despite the efforts of others so that they may try different ones. This relationship between loyalty and repeat purchases intention as shown on this definition is the result of many studies that prove it $(27,28,29)$

Several previous studies have shown the relationship between cocreation and loyalty $(30,31,32)$.

\section{Our proposed model}

In the literature review in this section the theoretical connections between co-creation and the identified key outcomes, as illustrated in Figure 1, have been demonstrated. These interrelationships of all these constructs are incorporated in to the model In particular, it is going to examine the mediating role of Satisfaction and Relationship strength in the impact of value co-creation on loyalty and also the direct impact of Co-creation on loyalty. The validity of this model and its connections will be the main reason for this research.

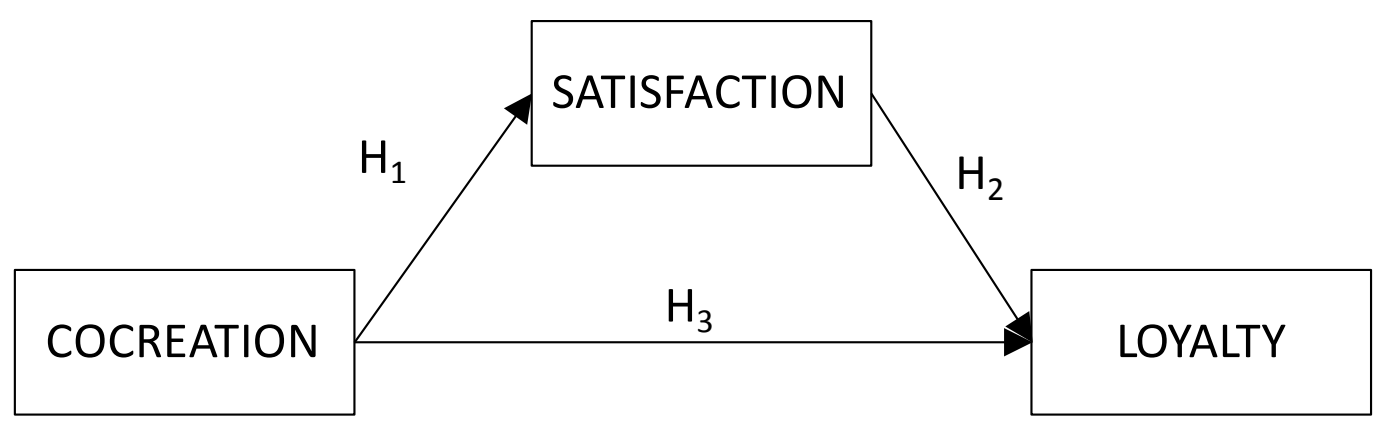


Fig 1: Proposed model for Co-creation and its hypostheses of relationship with Satisfaction and Loyalty

As mentioned, Fig 1 presents the proposed model with the research aim to ascertain to what extent co-creation affects the relational outcomes of student satisfaction and student loyalty. Also, the model proposes a relation between student satisfaction and student loyalty and also measures if satisfaction acts as a mediator in the relationship between co-creation and loyalty.

This research aim mentioned is addressed by a series of hypotheses developed in table 1:

\begin{tabular}{|l|l|l|}
\hline Hipótesis & Constructs & Items \\
\hline \multirow{2}{*}{$\begin{array}{l}\text { H1 Co-creation has a direct, positive effect } \\
\text { on satisfaction }\end{array}$} & CO-CREATION & $\begin{array}{l}\text { q18, q19, q20, } \\
\text { q21 }\end{array}$ \\
\cline { 2 - 3 } & SATISFACTION & q11, q12, q13 \\
\hline $\begin{array}{l}\text { H2 Satisfaction has a direct, positive effecto } \\
\text { on loyalty }\end{array}$ & SATISFACTION & q11, q12, q13 \\
\cline { 2 - 3 } & LOYALTY & q3, q4, q6 \\
\hline \multirow{2}{*}{$\begin{array}{l}\text { H3 Co-creation has a direct, positive effect } \\
\text { on loyalty }\end{array}$} & CO-CREATIONI & $\begin{array}{l}\text { q18, q19, q20, } \\
\text { q21 }\end{array}$ \\
\cline { 2 - 3 } & LOYALTY & q3, q4, q6 \\
\hline
\end{tabular}

Table 1: Hypotheses to be investigate in the model, constructs to which each hypothesis refers and questionnaire items related to this hypothesis and constructs. 
See table 2 for q ( q: questions)

\begin{tabular}{|c|c|}
\hline & $\begin{array}{l}\text { Thinking about your experience with this university, please indicate } \\
\text { agreement/disagreement with the } \\
\text { following statements, using the scale from "strongly disagree" (1) to "strongly agree" }\end{array}$ \\
\hline q3 & In the future, I intend to return to this university to continue with my studies \\
\hline q4 & The probability that I will consider this university again in the future is very high \\
\hline q6 & I intend to continue using this university for some time \\
\hline q11 & Overall, I am pleased with the services offered by this university \\
\hline q12 & The service offered by my university meets my expectations \\
\hline q13 & $\begin{array}{l}\text { We are interested in the concept of "customer co-creation," which occurs when a company and its cu } \\
\text { together to create a (purchase) solution. Now, please consider the passage we have just read respo } \\
\text { statements using the same scale from "strongly disagree" (1) to "strongly agree" (7), as before. }\end{array}$ \\
\hline q18 & Overall, I would describe my relationship with this university as involving a high leve \\
\hline q19 & $\begin{array}{l}\text { This university tries to ensure that the final service solution is due to the work of b } \\
\text { student }\end{array}$ \\
\hline q20 & The final purchase solution was arrived at mainly through the joint effort, the univers \\
\hline q21 & I contribute actively to the final solution in the educational service I receive \\
\hline
\end{tabular}

Table 2:

questionnaire 
As can be seen, the three variables are composed of a number of questions specifically selected from the questionnaire, creating our measurement scale. The choice of variables and their measurement scale is supported by the theoretical foundations discussed above, thus providing the model with conceptual consistency.

\section{4.- Methodology}

\subsection{Data Collection}

The targeted sample companies which have enrolled their managers in part time master programs The data necessary to be able to fulfill the objectives of the investigation and to contrast the propose hypotheses was obtained by a questionnaire in class time (face-to-face surveys) answered by the cited managers who are sponsored by their companies to take the part-time master . Rotation of items was introduced to reduce the error of measurement or method of collection (produced by the order in which the stimuli or the alternatives of answer appear) (common method bias). The total sample is of 196 adult students of part time masters from 2 differente spanish universities This sample size is the necessary minimum for the correct operation of the applied statistical methodology. Of them, $46 \%$ are women and 54\%, men. The used instrument was a scale of likert of 1 (totally in discord) to 7 (totally in agreement) for the answer of 21 items.

\section{2.. Measure development}

Multiple measures ( see Appendix A) were taken of all study constructs: Co-creation, Satisfaction and loyalty. It has been able to find a past study which addressed all of the issues in this research. For that reason, the questionary which has been used had been previously validated by Rajah et Al ( 2008) (15)

Constructs Mean ${ }_{\text {Deviation }}^{\text {Standard }}$ CocreationSatisfactionLoyalty

\begin{tabular}{|c|c|c|c|c|}
\hline Cocreation 4,85 & 1,03 & 1 & 848 & ,701 \\
\hline Satisfaction5,10 & 1,25 & 1,090 & 1 & ,691 \\
\hline Loyalty & 1,31 & 0,945 & 1,134 & 1 \\
\hline
\end{tabular}

Correlations are above the diagonal and covariances are below the diagonal

Table 3. Pearson correlations among measures, standard deviations and covariances 


\section{Empirical Results}

\subsection{Model and analysis}

The statistical methodology used to solve the raised hypotheses will be the causal analysis since it allows to analyze relations of causality between constructs that are not mesurables of a direct way, but which they are pronounced through certain observable characteristics. The type of causal analysis used will be the model of structure of covariance also called structural equations model (SEM) and it will be solved with AMOS 16.0

SEM methodology has been already used by different authors to measure the effects of Co-creation $(15,30)$, SEM methodology has been also used to measure empirically the influences between variables in the education sector (29,33 ). In the structural equation model of this study, we examined the two level of analysis-the measurement model and the structure model.

\subsection{The results of the measurement model}

Table 3 shows the means, standard deviations, correlations and covariances matrix of this study. In Table 3 , there were significantly positive correlations among relationships cocreation, loyalty and satisfaction. In addition, there are several measurements to confirm the level of reliability and validity (convergent and divergent) of the constructs. One measure of the reliability is to examine the loadings of each of the constructs' individual items. With respect to the quality of the measurements model for the sample, the loadings $(\lambda)$ of items of the constructs listed in Table 4 are significant and more than 0.5 , even 0.7 (Hair et al.,1999,). Cronbach's alpha is the other measure of the reliability. In agreement with Nunnally (1978), in an exploratory investigation it is required that this coefficient is equal or greater to 0.7 to be able to affirm that the scale is trustworthy. Table 4 listed Cronbach's alpha for the constructs and showed that cocreation's is 0.918 , loyalty's is 0.923 and satisfaction's is 0.943 . So, all of them are more than 0.7 and the measurement of this study was acceptable in reliability.

This study applied Fornell and Larcker's (35) measure of average variance extracted to access the convergent and discriminate validity of measurement. The AVE measures the amount of variance captured by the construct though its items relative to the amount of variance due to the measurement error. To satisfy the requirement of convergent validity the AVE for every construct must be more than 0.5 Hair et al (36). This is shown in Table 4, all AVE's are more even than 0.7 . So convergent validity is proved. To satisfy discriminate validity, the square root of a construct's AVE must be greater than the correlations between the construct and the other constructs in the model. For example, the square roots of the AVE's for the two constructs, satisfaction and loyalty, are 0.920 and 0.896 in Table 4 which are more than correlation, 0.691 , between them in Table 1 . This demonstrates there is adequate 
discriminate validity between 2 constructs. The square roots of all constructs's AVE in Table 4 of this study were also greater than the correlations among all constructs in Table 3. Therefore, the discriminate validity of the measurement in this study was acceptable.

\begin{tabular}{|c|c|c|c|c|c|}
\hline & ítems & $\begin{array}{l}\text { Factorial } \\
\text { loadings } \lambda \mathrm{i}\end{array}$ & $\begin{array}{l}\text { Cronbach's } \\
\alpha\end{array}$ & AVE & $\begin{array}{l}\text { The square } \\
\text { root of } A V E\end{array}$ \\
\hline$\xi 1$ & Q18 & 0,876 ** & 0.918 & 0,741 & 0.860 \\
\hline \multirow[t]{3}{*}{ Cocreation } & Q19 & 0,914 ** & & & \\
\hline & Q20 & 0,871 ** & & & \\
\hline & Q21 & 0.773 & & & \\
\hline & Q11 & 0,914 ** & 0.943 & 0.847 & 0.920 \\
\hline \multirow[t]{2}{*}{ Satisfaction } & Q12 & 0,943 ** & & & \\
\hline & Q13 & 0.904 & & & \\
\hline \multirow[t]{3}{*}{ ๆ2- Loyalty } & Q3 & $0,877^{\star \star *}$ & 0.923 & 0.803 & 0.896 \\
\hline & Q4 & 0,925 ** & & & \\
\hline & Q6 & 0.885 & & & \\
\hline
\end{tabular}

* $p$-value $<0.05$

** p-value $<0.01$

Table 4. The loadings $(\lambda)$ of items and the Cronbach's $\alpha$ coefficients and AVE's of the constructs

5.3. The results of the structural model

This section presented the main result of this research.

The use of models SEM allows to adjust better to the work frame that other techniques of more traditional analyses (linear regressions, for example) fundamentally by 2 reasons: Its confirming and nonexploratory approach that allows to contrast previously theorized hypotheses and Its capacity to estimate multiple relations for each group of dependent variables

The tested model with SEM notation is shown fig 2. 


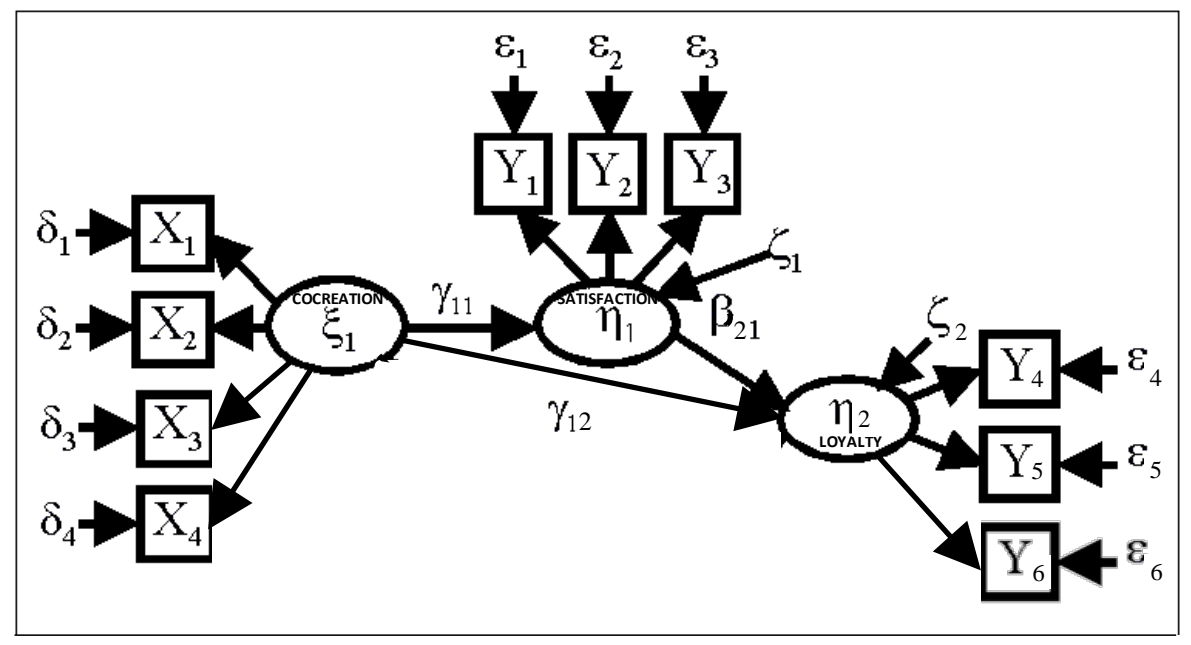

Fig 2: Model of the effects of Cocreation on Satisfaction and Loyalty

Overall, the model was judged to be a good fit with the data as most of the fit statistics very well within acceptable levels. As shown at the bottom of Table 5, for example, the comparative fit index (CFI) was closed to 1. Further, the root mean squared error of approximation (RMSEA), a fit index adjusted for degrees of freedom, was low than 0.08 which is the level suggested by Browne and Cudeck (37).

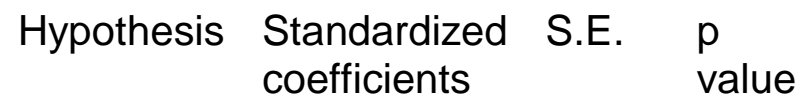
$(\beta)$

\begin{tabular}{|c|c|c|c|c|}
\hline \multicolumn{5}{|l|}{ Direct effects } \\
\hline $\begin{array}{l}\text { Cocreation- } \\
\rightarrow \text { Satisfaction }(\gamma 11)\end{array}$ & $\mathrm{H} 1$ & 0.848 & 0,088 & $<0.001$ \\
\hline $\begin{array}{l}\text { Satisfaction- } \\
\rightarrow \text { Loyalty }(\beta 21)\end{array}$ & $\mathrm{H} 2$ & 0.344 & 0,127 & 0,005 \\
\hline $\begin{array}{l}\text { Cocreation- } \\
\rightarrow \text { Loyalty ( } 12)\end{array}$ & H3 & 0.409 & 0,159 & $<0.001$ \\
\hline model fit índices* & & & & \\
\hline CMIN/DF & \multicolumn{4}{|c|}{$1.236(<3)$} \\
\hline CFI & \multicolumn{4}{|c|}{$0.994(>0.95)$} \\
\hline GFI & \multicolumn{4}{|c|}{$0.945(>0.95)$} \\
\hline AGFI & \multicolumn{4}{|c|}{$0.905(>0.80)$} \\
\hline SRMR & \multicolumn{4}{|c|}{$0.061(\sim 0.08)$} \\
\hline RMSEA & \multicolumn{4}{|c|}{$0.024(<0.08)$} \\
\hline
\end{tabular}

Table 5. Structural model results: estimates and model fit

In addition to the overall statistical fit of the model, it also explained a reasonable amount of the variance in each of the relationship outcome variables, Satisfaction, Loyalty and Cocreation. Half of the variance in the Loyalty variable was explained (squared multiple correlation $(S M C)=52 \%$ ) by the direct direct and indirect effects of Cocreation and Satisfaction. Even more 
of the variance in the Satisfaction variable $(\mathrm{SMC}=72 \%)$ was explained by the direct effect of Cocreation variable.

Therefore, Co-creation has a significant and positive impact on Satisfaction $(\gamma 11=0.848, p$-value $<0.001)$ as several authors have already stressed in the past (38). The rest of relations is all statistically significant and positive since therefore indicates the $p$-values associated to the regression coefficients. The relation between cocreation and satisfaction is the strongest relation (its coefficients $\mathrm{\gamma} 110.848$ is greater of 0,75 and its significance is to 99\%) whereas the relations between Satisfaction and Loyalty and cocreation and loyalty are weaker (coefficients $\beta 21$ and $\gamma 12,0.344$ and 0.409 , respectively, are around 0,35 and significance to $99 \%$ ).

To complete the analysis of $\mathrm{H} 3$, mediation must be tested. As Baron and Kenny (39) point out, to establish mediation, one has to show that (1) the relationship between the initial variable, cocreation and the outcome variable Loyalty is significantly correlated (a), (2) the initial variable is correlated with the mediator, Satisfaction (c), (3)the mediator, satisfaction, affects the outcome variable, loyalty (d) and (4) the effect of the initial variable, cocreation, on the outcome variable, Loyalty (b), decreases in both significance and magnitude when the mediator is added to the model. As it is shown in Table 6, the mediation of the Satisfaction in the relation between cocreation and loyalty is partial so that the direct influence between cocreation and loyalty is almost reduced half in the presence of the Satisfaction.

Table 6: Mediation

\begin{tabular}{llrlrl} 
Relation & $\begin{array}{l}\text { Direct } \\
\text { without } \\
(\mathrm{a})\end{array}$ & $\begin{array}{r}\text { effect } \\
\text { mediator }\end{array}$ & $\begin{array}{l}\text { Direct } \\
\text { with } \\
\text { (b) }\end{array}$ & $\begin{array}{r}\text { effect } \\
\text { mediator }\end{array}$ & $\begin{array}{l}\text { Indirect Effect } \\
\left(\mathrm{c}^{\star} \mathrm{d}\right)\end{array}$ \\
\hline $\begin{array}{l}\text { Cocreation } \\
\text { Satisfaction Loyalty }\end{array}$ & $0.700(<0.001)$ & $0.409(<0.001)$ & $\begin{array}{l}0.292 \\
\text { Partial }\end{array}$ & $(0.024)$ \\
\hline
\end{tabular}

Table 6: Mediation

Thus, it may be concluded that Satisfaction partially acts as mediator in the relationship between Co-creation and Loyalty, as shown in Fig 3, so that the direct effect between Co-creation and Loyalty is almost reduced by half in the presence of Satisfaction.

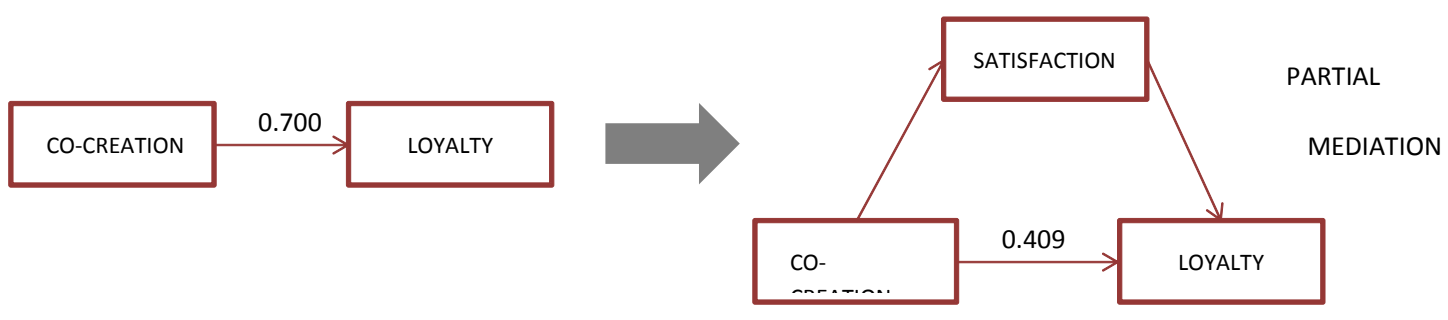


Fig 3: Mediation of satisfaction between loyalty and co-creation

Therefore, by way of summary, the main conclusions of the model are presented as it can be seen in Table 7:

Co-creation influences deeply and in a positive way on student Satisfaction $(\mathrm{H} 1$, regression coefficient 0.85$)$.

Satisfaction influences moderately and in a positive way on student Loyalty $(\mathrm{H} 2$, regression coefficient 0.34$)$.

Co-creation influences moderately and in a positive way on student Loyalty $(\mathrm{H} 3$, regression coefficient 0.41$)$.

Satisfaction partially acts as mediator in the relationship between CoCreation and Loyalty.

\begin{tabular}{|c|c|c|c|c|}
\hline & $\begin{array}{l}\text { Direction } \\
\text { Magnitude }\end{array}$ & and & Result & Mediation \\
\hline $\mathrm{H} 1$ & $\begin{array}{l}\text { Positive } \\
\text { strong }\end{array}$ & and & $\begin{array}{l}\text { Not } \\
\text { rejected }\end{array}$ & \\
\hline $\mathrm{H} 2$ & $\begin{array}{l}\text { Positive } \\
\text { weak }\end{array}$ & and & $\begin{array}{l}\text { Not } \\
\text { rejected }\end{array}$ & \\
\hline H3 & $\begin{array}{l}\text { Positive } \\
\text { weak }\end{array}$ & and & $\begin{array}{l}\text { Not } \\
\text { rejected }\end{array}$ & $\begin{array}{l}\text { Measured } \\
\text { Satisfaction }\end{array}$ \\
\hline
\end{tabular}

Table 7: Summary of Results of the Hypotheses

\section{6.-Conclusiones, contributions and implications}

Recent research in management has increasingly been drawn to the concepts and ideas encompassed by co-creation and its consequences. In this paper we have introduced and developed this concept related to Educational institutions. The aim of our research is to check to what extent co-creation contributes to satisfaction and loyalty among students who participate in the process of co-creation with educational institutions. Therefore, the contribution of this study's findings is to provide statistical support to show the influence between co-creation and the constructs proposed in the model, namely satisfaction and loyalty.

From the analysis of information it can be concluded that the student's participation in co-creation with the university leads to higher levels of satisfaction and to greater loyalty by the student to the educational institution.

As mentioned, this study has validated the proposed SEM model, thus it can be stated that all the efforts from educational institutions for greater student involvement as co-creator of the service will result in greater satisfaction and loyalty to the institution. Consequently, this work suggests that co-creation has the potencial to create value outcomes for both students and universities. On the one hand, the students are more satisfied with the institution. On the other hand, the university, as a consequence of that higher level of satisfaction, 
increases its level of students` loyalty.Considering the potential consequences of that mentioned student loyalty, the benefits for the university are increased revenues, reduced customer acquisition costs, and lower costs of serving repeat purchasers, thus resulting in greater profitability as stated by Reichheld (40) in his study of the consequences of loyalty.

From a managerial point of view, in a moment with high competition as the present one for educational institutions, with a need for universities to differentiate themselves for competition, co-creation appears to be a useful tool to get that differentiation.This study provides Educational Institutions Managers with knowledge to better plan for the resource and marketing implication in implementing co-creation strategies with their students. Therefore, those educational institutions to implement co-creation projects can develop a competitive strategy that will generate more value for students and which will also be difficult to imitate by the competition, as Cova et al (41) point out.

For co-creation to take place, both universities and students should be united and work hand in hand in order to create a better service and a differentiated product. This research has shown that all this will result in greater value and greater satisfaction for the student and, consequently, higher levels of loyalty to the university.

This research is innovative both due to the profile of the students -as it is conducted among postgraduate students- and due to the fact that this relationships between the outlined constructs had never been suggested before by means of a quantitative study in the education sector. The results of this study contribute to marketing knowledge to the ongoing debate by demonstrating empirically that co-creation generates positive outcomes

Future studies should both further explore and replicate the model with undergraduate students where loyalty is even more strategic for educational institutions. They should also consider gender aspects by comparing the results, male vs. female hypothesis and investigating whether there are any differences. 


\section{References}

(1) Hemsley-Brown J, Oplatka I. Universities in a competitive global marketplace: A systematic review of the literature on higher education marketing. International Journal of Public Sector Management 2006;19(4):316-338.

(2) Mansfield PM, Warwick J. Gender differences in students' and parents' evaluative criteria when selecting a college. Journal of Marketing for Higher Education 2006;15(2):47-80.

(3) Maringe F. The meanings of globalization and internationalization in HE: Findings from a world survey. Globalization and internationalization in higher education: Theoretical, strategic and management perspectives 2010:17-34.

(4) Simões C, SoaresAM. Applying to higher education: information sources and choice factors. Studies in Higher Education 2010;35(4):371-389.

(5) Moore D, Bowden-Everson JL. An Appealing Connection-The Role of Relationship Marketing in the Attraction and Retention of Students in an Australian Tertiary Context. Asian Social Science 2012;8(14):p65.

(6) Helgesen $\varnothing$. Marketing for higher education: A relationship marketing approach. Journal of Marketing for Higher Education 2008;18(1):50-78.

(7) PrahaladCK, Ramaswamy V. Co-opting customer competence. Harv Bus Rev 2000;78(1):79-90.

(8) Von Hippel E. Democratizing innovation: The evolving phenomenon of user innovation. Journal fürBetriebswirtschaft 2005;55(1):63-78.

(9) ShethJN, Sisodia RS, Sharma A.The antecedents and consequences of customer-centric marketing. Journal of the Academy of Marketing Science 2000;28(1):55-66.

(10) Mathis EF. The Effects of Co-Creation and Satisfaction on Subjective Well-Being 2013.

(11) Carvalho SW, de Oliveira Mota M. The role of trust in creating value and student loyalty in relational exchanges between higher education institutions and their students.Journal of Marketing forHigherEducation 2010;20(1):145-165.

(12) Giner GR, Peralt A. Métodos y técnicas facilitadoras de la cocreationinnovation en programas máster para el mercado del postgrado. Intangible Capital 2014;10(1).

Peralt-Rillo A, Ribes-Giner G. A proactive market orientation for the postgraduate programs.Dirección y Organización 2013(50):37-47.

(14) Díaz-Méndez M, Gummesson E. Value co-creation and university teaching quality: Consequences for the European Higher Education Area (EHEA). Journal of Service Management 2012;23(4):571-592. 

marketers co-creating a purchase experience. Advances in Consumer Research 2008;35:367-373.

Storbacka K, Strandvik T, Grönroos C. Managing customer relationships for profit: the dynamics of relationship quality. International journal of service industry management 1994;5(5):21-38.

Ledden L, KalafatisSP, Samouel P. The relationship between personal values and perceived value of education. Journal of Business Research 2007;60(9):965-974.

Shaw G, Bailey A, Williams A. Aspects of service-dominant logic and its implications for tourism management: Examples from the hotel industry. Tourism Management 2011;32(2):207-214.

Lee SM, Olson DL, Trimi S. Co-innovation: convergenomics, collaboration, and co-creation for organizational values. Management Decision 2012;50(5):817-831.

(20) Grissemann US, Stokburger-Sauer NE. Customer co-creation of travel services: The role of company support and customer satisfaction with the co-creation performance. Tourism Management 2012;33(6):1483-1492.

Arnett DB, German SD, Hunt SD. The identity salience model of relationship marketing success: The case of nonprofit marketing. J Market 2003;67(2):89-105.

(22) Hennig-Thurau T, Malthouse EC, Friege C, Gensler S, Lobschat L, Rangaswamy A, et al. The impact of new media on customer relationships. Journal of Service Research 2010;13(3):311-330.

Marzo-Navarro M, Pedraja-Iglesias M, Rivera-Torres MP. Measuring customer satisfaction in summer courses. Quality Assurance in Education 2005;13(1):53-65.

Mavondo FT, Tsarenko Y, Gabbott M. International and local student satisfaction: resources and capabilities perspective. Journal of Marketing for Higher Education 2004;14(1):41-60.

Kumar V, Shah D. Expanding the role of marketing: from customer equity to market capitalization. J Market 2009;73(6):119-136.

Zhang JQ, Dixit A, Friedmann R. Customer loyalty and lifetime value: an empirical investigation of consumer packaged goods. The Journal of Marketing Theory and Practice 2010;18(2):127-140.

(27) Olsen SO, Mai HTX. Consumer participation: The case of home meal preparation. Psychology \& Marketing 2013;30(1):1-11.

Liang C, Wang W. Integrative research into the financial services industry in Taiwan: Relationship bonding tactics, relationship quality and behavioural loyalty. Journal of Financial Services Marketing 2005;10(1):65-83. 
(29) Chinomona R, Sandada M. Service Quality Level as the Determinant of Consumer Emotional Loyalty and Fantasy in South Africa's Pick \& Pay Chain Stores. Mediterranean Journal of Social Sciences 2013;4(3):579.

(30) Kotze TG, Du Plessis P. Students as "co-producers" of education: a proposed model of student socialisation and participation at tertiary institutions. Quality Assurance in Education 2003;11(4):186-201.

Auh S, Bell SJ, McLeod CS, Shih E. Co-production and customer loyalty in financial services. J Retail 2007;83(3):359-370.

Hoyer WD, Chandy R, Dorotic M, Krafft M, Singh SS. Consumer cocreation in new product development. Journal of Service Research 2010;13(3):283-296.

Moore D, Bowden-Everson JL. An Appealing Connection-The Role of Relationship Marketing in the Attraction and Retention of Students in an Australian Tertiary Context. Asian Social Science 2012;8(14):p65. Madrid.

Hair JF, Suárez MG. (1999). Análisis multivariante. : Prentice Hall

Fornell C, Larcker DF. Evaluating structural equation models with unobservable variables and measurement error. J Market Res 1981:39-50. ed2010.

Hair J, Black W, Babin B, Anderson R. Multivariate data analysis. 7th model fit.Sage Focus Editions, 154, 136-136.

Shaw G, Bailey A, Williams A. (2011).Aspects of service-dominant logic and its implications for tourism management: Examples from the hotel industry. Tourism Management;32(2):207-214.

Baron, R. M., \& Kenny, D. A. (1986). The moderator-mediator variable distinction in social psychological research: Conceptual, strategic, and statistical considerations. Journal of personality and social psychology, 51(6), 1173.

(40) Reichheld, F. F. (1992). Loyalty-based management. Harvard business review,71(2), 64-73.

Cova B, Dalli D, Zwick D. Critical perspectives on consumers' role as 'producers': Broadening the debate on value co-creation in marketing processes. Marketing Theory 2011;11(3):231-241. 


\section{CAPÍTULO 6}

VALUE CO-CREATION IN THE MULTI-STAKEHOLDER "UNIVERSITYCOMPANY-EMPLOYEE" SYSTEM AS A MARKETING STRATEGY FOR EDUCATIONAL INSTITUTIONS 


\title{
Value Co-creation in the multi-stakeholder "university-company- employee" system as a marketing strategy for educational institutions
}

Agustín Peralt (aperaltrillo3@gmail.com). Universidad Europea de Valencia

Department of Business Management

Gabriela Ribes Giner (gabrigi@omp.upv.es). Universidad Politécnica de Valencia

Faculty of Business Administration and Management

\begin{abstract}
This article aims to determine the impact of business-to-business value co-creation in a particular multi-stakeholder "university-company-employee" system. We have studied the value co-creation process in the postgraduate educational sector focusing on the relationship between managers sent by their companies to enroll in a part-time master's course and the university offering that program is examined through a quantitative study.

Using a conceptual research model with some hypothesized relations based on an in-depth literature review, we have measured empirically the impact of value cocreation on the key marketing outcomes of satisfaction, relationship strength, and loyalty towards the university in this business-to-business service context. A structural equation model (SEM) is used to test the hypotheses. The results are useful for considering co-creation as an essential tool related to the marketing policies of educational institutions. This can help them differentiate themselves from the competition in a complex sector such as postgraduate education in which the loyalty of the companies towards the educational institutions is key.
\end{abstract}

Keywords: Business-to-business co-creation, master's degree, satisfaction, loyalty, relationship strength, managers. 


\section{Introduction}

While some research has focused on value co-creation for universities in business-to-consumer (B2C) contexts (Bovill et al., 2011), value co-creation for educational institutions is also important in business-to-business (B2B) contexts when considering company enrolment of employees in postgraduate education (Mintzberg \& Gosling, 2002; Nicholls, Harris, Morgan, 1995). To date, however, limited attempts have been made to conceptualize B2B value co-creation in a particular multi-stakeholder system, namely "university-company-employee."

Postgraduate educational institutions are facing increasing competition globally due to today's critical economic situation, the global economy, and the introduction of on-line education programs (Schimel et al., 2011). One of the most important objectives of any university in the postgraduate market is attracting and retaining students suited to the courses offered (Veloutsou et al., 2004). The university's marketing management has to gain a sound understanding of the choice decision process and develop the right strategies according to previous research in order to ensure both the students' decision to enrol on their program and their satisfaction with it when the service is received (Kotler \& Fox, 1995). In this increasingly competitive situation, the need for strategies that will provide a leading edge in the sector is evident. Moreover, Nicolescu (2009) suggests that the marketing field is yet to be developed and adapted for the postgraduate sector, and that in addition to promotion and communication, there are many other aspects determining student satisfaction that have to be considered. Also, Temple (2009) have noted "most universities are actually doing (or they say are) very like most other universities", rather than focusing on differentiation. Enache (2011) suggest that a framework able to provide relevant information and suitable instruments will improve the market presence of any postgraduate institution. In the same vein, Maringe and Gibbs (2009) have found that one of the new lessons universities are learning from business and the commercial world today is how to develop a customer perspective.

In addition, there has been increasing demand in the last decade for postgraduate programs (B-School GMAC, 2010) from consumers (companies and their professionals) to meet evolving educational needs. This particularly relates to part-time postgraduate programs, reflecting the need for professionals undertaking further eduction to do so while working in their present jobs. Such eduction is considered necessary by both the professionals themselves and by the employers, not only to develop talent within the company but also as a way of motivating employees. Some companies reimburse costs and sponsor those enrolling in such programs as an employee benefit (Kotler \& Fox, 1995).

The aim of this research is to consider the benefits of B2B value cocreation between universities and companies through master's programs in which the companies' employees are enrolled. These benefits are measured through quantitative research aiming to validate the impact of $\mathrm{B} 2 \mathrm{~B}$ value cocreation on satisfaction, relationship strength and the loyalty of the companies' 
managers towards the university, proposing and empirically analyzing a conceptual model.

The article is organized as follows. In section 2, the theorical background is discussed, briefly reviewing the literature on customer co-creation and the possible relationships between co-creation and marketing outputs in order to suggest a model for later validation. The methodology, structural equation modeling (SEM), is described in section 3, prior to its use in validating the model. In section 4, the results of the quantitative study are presented. Finally, the results are discussed, and conclusions, limitations and recommendations for further research are presented in section 5.

\section{Background, Hypotheses and Conceptual Model}

In developing our conceptual model (see 2.7, Fig. 1), a range of literature is reviewed on marketing concepts that are relevant to this research focus, such as co-creation, satisfaction, relationship strength, and loyalty. On the basis of this review, the key constructs of our model are defined. At the same time, the theoretical bases and existing evidence supporting the relationships shown in the model are described.

\subsection{Co-creation for educational institutions}

The term "open innovation" has been used to characterize a system in which innovation is not solely perfomed internally within a firm, but in a cooperative mode with other external actors (Chesbrough, 2003; Fredberg et al., 2008). Piller and Vossen (2011) introduced the term "customer co-creation" to define strategies of open innovation with customers. For Prahalad and Ramaswamy (2004), the co-creation concept represents a unique way of creating value for customers. Vargo and Lusch (2008) define this co-creation concept as the way in which companies deal with their customers through customer participation in the joint creation of service value. In this respect, Hasche (2006) concludes that the focus has shifted from the activities performed by the firm to activities co-created in a relationship with other partners and stakeholders. Ramaswamy (2009) adds that sustainable cocreation with customers cannot be accomplished unless value is created for employees. These authors propose that a transformation should occur in traditional corporate practices, such as training, performance management and communications, turning them into co-creative interactions. In the same vein, Gustafson et al. (2012) argue that co-creation involves different forms of communication and interaction with consumers and their environment during the value creation process.

In service-dominant (S-D) logic, the customer is an operant resource and someone with whom the firm can co-create value (Nam \& Lee, 2010). As Yi and Gong (2012) state, the core concept of S-D logic is that the customer is always a co-creator of value with the firm through involvement in the entire service value chain. This implies developing a dialog between parties that is founded on 
trust, learning together, and adapting to each other. It aims "at developing an understanding of each participant's point of view, and interaction sets up suitable conditions for listening and learning together" (Ballantyne et al., 2011). Ballantyne et al. (2011) assert that buyers and sellers are participants in interactive communication processes in which solutions emerge through a mutually-constructed dialog under an S-D logic perspective.

Central to this business philosophy is the adoption of collaborative processes and methods, as well as collaboration as a general philosophy of business. This occurs not only between market-facing service systems but also other private and public service systems (Lusch et al., 2010). Related to B2B contexts, Ulaga (2011) highlights the buyer-seller's perspective that focuses on joint value creation. Therefore, value is derived from the service experience of the particular actors in the interaction (Haas et al., 2012). Jaakkola and Hakanen (2013) introduce the term "solution network" to denote the set of actors, suppliers and customers that are connected to each other for the purpose of integrating their resources to co-create value through solutions. Along the same lines, Basole and Rouse (2008) define a "value network" as a solution that integrates all participants or actors, such as suppliers, partners and customers, and integrates various resources that other actors have.

In our research, this "solution network" or "value network" is related to a multi-actor system under the S-D logic, such that universities and companies co-create value. Recent studies (Giner \& Peralt, 2014) have considered the concept of co-creation in the B2B context of universities and companies that enrol their managers in university courses.

In the following literature review, the aim is to find possible relations between co-creation and its key marketing output to suggest a model for later validation. This model is intended to respond to a number of issues raised by Rajah et al. (2003), who stress the need for empirical studies that demonstrate the impact and consequences of the implementation of co-creation in different sectors from a marketing perspective. The interrelationships between all these constructs are incorporated within the model for testing in a B2B setting. In particular, we examine the mediating role of satisfaction and relationship strength in relation to the impact of value co-creation on loyalty, and also the direct impact of co-creation on loyalty.

\subsection{Co-creation and satisfaction}

In education, student satisfaction is defined as the subjective assessment carried out by the student him/herself of his/her experiences and results in relation to the education provided and student life (Storbacka, Strandvik, \& Gronroos, 1994). Customer satisfaction in B2B contexts is often defined as a positive affective state resulting from the appraisal of all aspects of a firm`s working relationship with another firm (Geyskens, Steenkamp, \& Kumar,1999). In reviewing the literature, several authors stress the positive and direct relationship between co-creation and satisfaction (Dong, Evans, \& Zou, 2008; Grissemann \& Stokurger-Sauer, 2012; Lee et al, 2012; Shaw et al., 2011). Thus, our initial hypothesis is as follows: 
H1 Co-creation has a direct, positive effect on satisfaction.

\subsection{Satisfaction and loyalty}

In the education market, several studies stress the positive relationship between satisfaction and the loyalty of the student (Bowden \& D'Alessandro, 2011; Helgesen, 2007; Hennig-Thurau et al., 2011; March-Navarro, Pedraja, \& Rivera, 2005; Mavondo et al., 2004). Furthermore, Moore and Bowden-Everson (2012) find a positive relationship between satisfaction and loyalty using a quantitative SEM approach at an educational institution.

Empirical B2B support for positing such a direct relationship from a theoretical point of view is found in Sheth's (1973) B2B model, which hypothesizes that buyer satisfaction with past supplier actions will influence subsequent industrial buyer behavior. Thus, our second hypothesis is as follows:

H2 Satisfaction has a direct, possitive effect on loyalty.

\subsection{Co-creation and loyalty}

In B2B contexts, loyal customers could derive personal, non-economic satisfaction from repeated social exchange with a seller, and consequently find the overall experience with a service provider more satisfying than disloyal customers (Lam et al., 2004). Zhang et Al (2010) defines loyalty as commitment from consumers, demonstrated by making repeat purchases from the same company despite the efforts of others to entice them to try different ones. This relationship between loyalty and repeat purchase intention has been corroborated in many studies (Chinomona \& Sandala, 2013; Mai \& Ness, 2006; Meng Liang \& Yan, 2011), and several previous studies have shown the relationship between co-creation and loyalty (Auh et al., 2007; Hoyer et al., 2010; Kotze \& du Plessis, 2003).

As a result of increased competition between educational institutions, many authors have focused on the study of student loyalty (Arnett et al., 2003; Carvaloho \& de Oliveira Mota, 2010; Hennig-Thurau et al, 2010). In the specific case of the education sector, the literature furthers the concept by referring to student loyalty as long-lasting even after having completed their studies; subsequent behavioral patterns of students include donations, alumni membership, social participation, and positive recommendations of the same institution (March-Navarro, Pedraja, \& Rivera, 2005). Thus, we hypothesize as follows:

H3 Co-creation has a direct, positive effect on loyalty. 


\subsection{Co-creation and relationship strength}

Moore and Bowden-Everson (2012) note that the relationship between the student and the educational institution is gaining in importance considering the need for institutions to retain students in such a highly competitive sector. Among the many previous studies that have highlighted the positive relationship between co-creation and relationship strength (e.g., Boyle 2007; Edmonds, 2008; Evantschitzky, 2007), $\mathrm{Ng}$ and Forbes (2009) in particular note the effect of co-creation when it comes to strengthening the relationship between universities and students. Thus, we hypothesize that:

H4 Co-creation has a direct, positive effect on relationship strength.

\subsection{Relationship strength and loyalty}

There have been several previous studies that have argued the existence of a direct correlation between relationship strength and positive referral and loyalty (Bove and Jhonson, 2001; Mattila, 2006; Ng \& Forbes, 2009; Zander and Zander., 2005; Cugini et al., 2007). Indeed, Rajah et al. (2012), based on a quantitative study, state that relationship strength is an antecedent of customer loyalty.

In a B2B context, Caceres and Paparoidamis (2007) show, with empirical verification, the mediating role of overall relationship in the formation of loyalty towards the supplier. Verhoef (2003) shows the same direct relation of these two constructs with his empirical research. On this basis, we hypothesize thus:

H5 Relationship strength has a direct, positive effect on loyalty.

\subsection{Hypothesized model}

Through the review of the literature, the theoretical connections between co-creation and key outcomes have been identified, as illustrated in Fig. 1. The interrelationships between all these constructs are incorporated in the model, tested in a B2B setting. In particular, we examine the mediating role of satisfaction and relationship strength in the impact of value co-creation on loyalty, and also the direct impact of co-creation on loyalty. 


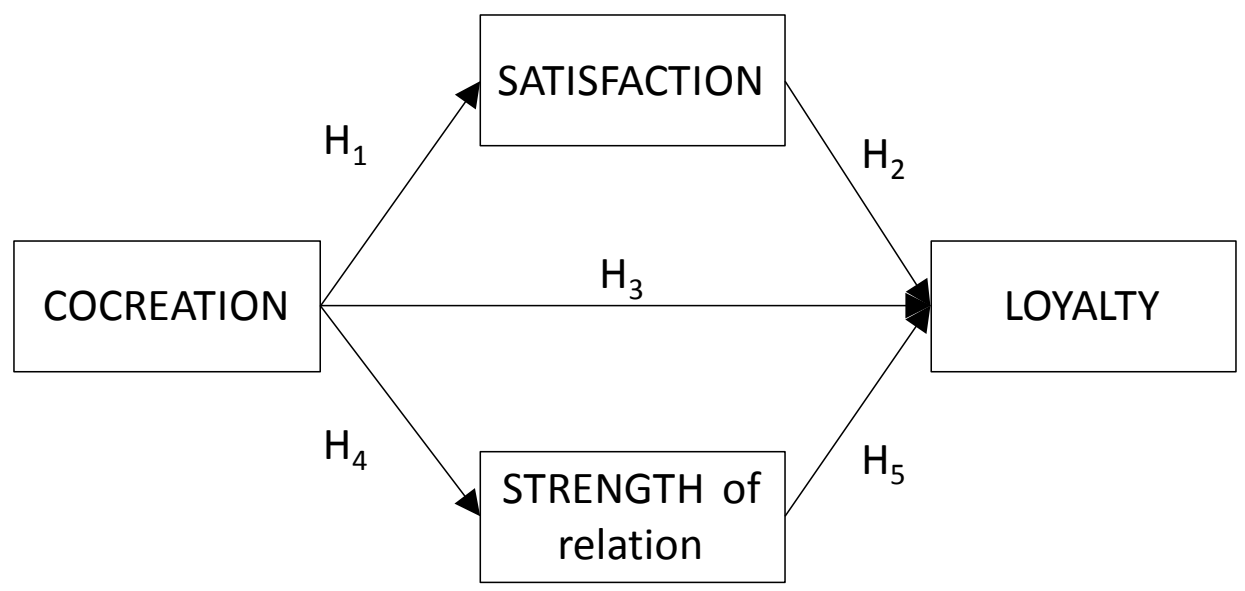

Fig. 1: Proposed model for co-creation and its relationship with satisfaction, strength of relation and loyalty

As can be seen in Table 1, the three variables illustrated in the model relate to a number of questions specifically selected from the questionnaire, creating our measurement scale. The choice of variables and their measurement scales is supported by the theoretical foundations discussed above, thus providing the model with conceptual consistency.

Table 1: Hypothetical links in the model to be investigated, constructs to which the hypotheses relate, and questionnaire items related to hypotheses and constructs.

\begin{tabular}{|c|c|c|}
\hline Hypothesis & Construct & Items \\
\hline \multirow{2}{*}{$\begin{array}{l}\text { H1 Co-creation has a direct, positive } \\
\text { effect on satisfaction }\end{array}$} & CO-CREATION & $\begin{array}{l}\text { q18, q19, } \\
\text { q20, q21 }\end{array}$ \\
\hline & SATISFACTION & $\begin{array}{l}\text { q11, q12, } \\
\text { q13 }\end{array}$ \\
\hline \multirow{2}{*}{$\begin{array}{l}\text { H2 Satisfaction has a direct, positive } \\
\text { effect on loyalty }\end{array}$} & SATISFACTION & $\begin{array}{l}\text { q11, q12, } \\
\text { q13 }\end{array}$ \\
\hline & LOYALTY & $\begin{array}{l}\text { q3, } \\
\text { q6 }\end{array}$ \\
\hline \multirow{2}{*}{$\begin{array}{l}\text { H3 Co-creation has a direct, positive } \\
\text { effect on loyalty }\end{array}$} & CO-CREATION & $\begin{array}{l}\text { q18, q19, } \\
\text { q20, q21 }\end{array}$ \\
\hline & LOYALTY & $\begin{array}{l}\text { q3, } \\
\text { q6 }\end{array}$ \\
\hline \multirow{2}{*}{$\begin{array}{l}\text { H4 Co-creation has a direct, positive } \\
\text { effect on relationship strength }\end{array}$} & CO-CREATION & $\begin{array}{l}\text { q18, q19, } \\
\text { q20, q21 }\end{array}$ \\
\hline & $\begin{array}{l}\text { RELATIONSHIP } \\
\text { STRENGTH }\end{array}$ & $\begin{array}{l}\text { q8, } \\
\text { q10 }\end{array}$ \\
\hline $\begin{array}{l}\text { H5 Relationship strength has a direct, } \\
\text { positive effect on loyalty }\end{array}$ & $\begin{array}{l}\text { RELATIONSHIP } \\
\text { STRENGTH }\end{array}$ & $\begin{array}{l}\text { q8, } \\
\text { q10 }\end{array}$ \\
\hline
\end{tabular}


\begin{tabular}{|l|l|l|}
\hline & LOYALTY & $\begin{array}{l}\text { q3, q4, } \\
\text { q6 }\end{array}$ \\
\hline
\end{tabular}

See Appendix A for questionnaire items (q).

\section{Methodology}

\subsection{Data Collection}

The targeted sample comprised companies that enrolled their managers in part-time master's programs. The data necessary to fulfill the objectives of the investigation and to contrast the hypotheses proposed were obtained through a questionnaire completed in class time (face-to-face surveys), completed by managers sponsored by their companies to undertake the parttime master's degree. The items were rotated to reduce the error of measurement or errors introduced by virtue of the method of collection (produced by the order in which the stimuli or the alternatives of answers appear) (common method bias). The total sample comprised 200 adult students, professionals sent by their companies, in part-time master's programs from two different Spanish universities. The sample size is the necessary minimum for the correct operation of the statistical methodology applied. Of these, $46 \%$ were women and $54 \%$ were men. The instrument used was a seven-point Likert scale, anchored at 1 (in total disagreement) and 7 (in total agreement), for the 21 questionnaire items.

\subsection{Measure development}

Multiple measures (see Appendix A) were employed for all study constructs: co-creation, satisfaction, relationship strength, and loyalty. All the issues examined in this research were previously studied by Rajah et al. (2008), and thus their previously validated questionnaire was employed in this study.

\section{Empirical Results}

\subsection{Model and analysis}

The statistical methodology used to examine the study hypotheses is causal analysis as it allows the analysis of causal relations between constructs that are not directly measurable, but which are discerned through certain observable characteristics. The type of causal analysis used is the model of structure of covariance, also called a structural equation model (SEM), and it is estimated using AMOS 16.0. In the SEM, we examine two levels of analysis: the measurement model and the structural model. 
Table 2 shows the means, standard deviations, and correlation and covariance matrices. As can be seen, there are significantly positive correlations between co-creation, loyalty, relationship strength, and satisfaction.

Table 2: Pearson correlations among measures, standard deviations and covariances

\begin{tabular}{lllllll} 
Constructs & Mean & \multicolumn{3}{c}{$\begin{array}{c}\text { Standard } \\
\text { Deviation }\end{array}$} & \multicolumn{3}{c}{ Co-creation Satisfaction Loyalty } & Strength \\
\hline Co-creation & 4.85 & 1.03 & 1 & .849 & .701 & .750 \\
Satisfaction & 5.10 & 1.25 & 1.096 & 1 & .690 & .729 \\
Loyalty & 4.59 & 1.31 & 0.951 & 1.132 & 1 & .594 \\
Strength & 4.47 & 1.37 & 1.061 & 1.246 & 1.067 & 1
\end{tabular}

Correlations are above the diagonal and covariances are below the diagonal

In addition, several measures are used to confirm the level of reliability and validity (convergent and divergent) of the constructs (see Table 3). One measure of reliability is to examine the loadings of each of the constructs' individual items. With respect to the quality of the measurement model for the sample, the loadings $(\lambda)$ of items of the constructs listed in Table 2 are significant and greater than 0.5 , or even 0.7 (Hair and Suarez ,1999). Cronbach's ( Cronbach, 1951) alpha is the other measure of reliability. Following Nunnally (1978), in an exploratory investigation it is required that this coefficient be equal to or greater than 0.7 to affirm that the scale is trustworthy. Table 3 shows the Cronbach's alpha values for the constructs, all of which are greater than 0.7 , thus demonstrating acceptable reliability.

In this study, we also apply Fornell and Larcker's (1981) measure of average variance extracted (AVE) to access the convergent and discriminant validity of the measurement scale. The AVE measures the amount of variance captured by the construct though its items relative to the amount of variance due to the measurement error. To satisfy the requirement of convergent validity, the AVE for every construct must be greater than 0.5 (Hair, Black, , Babin, \& Anderson, 2010). The AVE values shown in Table 3 are all greater than 0.7, thus demonstrating convergent validity. To show discriminant validity, the square root of a construct's AVE must be greater than the correlations between the construct and the other constructs in the model. For example, the square roots of the AVEs for the two constructs, satisfaction and loyalty, are 0.920 and 0.896 , respectively, which are greater than the correlation between them, 0.690, given in Table 2; this demonstrates that there is adequate discriminant validity for the two constructs. The square roots of all AVEs for the constructs shown in Table 3 are greater than the correlations between all constructs as shown in

Table 2. Therefore, the discriminant validity of the measurement model in this study is acceptable. 
Table 3: Loadings $(\lambda)$ of items, and Cronbach's a coefficients and AVEs of the constructs

\begin{tabular}{|c|c|c|c|c|c|}
\hline & Item & $\begin{array}{l}\text { Factorial } \\
\text { loadings } \lambda_{\mathrm{i}}\end{array}$ & $\begin{array}{l}\text { Cronbach's } \\
\alpha\end{array}$ & AVE & $\begin{array}{l}\text { Square } \\
\text { root of } \\
\text { AVE }\end{array}$ \\
\hline \multirow[t]{4}{*}{$\xi_{1}$ Co-creation } & P18 & $0.876^{\star \star}$ & 0.918 & 0.741 & 0.860 \\
\hline & P19 & $0.91^{\star \star}$ & & & \\
\hline & P20 & $0.874^{\star \star}$ & & & \\
\hline & P21 & 0.778 & & & \\
\hline \multirow[t]{3}{*}{$\eta_{1}$ Satisfaction } & P11 & $0.916^{\star \star}$ & 0.943 & 0.847 & 0.920 \\
\hline & $\mathrm{P} 12$ & $0.942^{\star \star}$ & & & \\
\hline & P13 & 0.902 & & & \\
\hline \multirow[t]{3}{*}{$\eta_{2}$ Strength } & P8 & $0.836^{\star \star}$ & 0.928 & 0.816 & 0.903 \\
\hline & P9 & $0.945^{\star \star}$ & & & \\
\hline & P10 & 0.926 & & & \\
\hline \multirow{3}{*}{$\eta_{3}$ Loyalty } & P3 & $0.876^{\star *}$ & 0.923 & 0.803 & 0.896 \\
\hline & P4 & $0.925^{\star \star}$ & & & \\
\hline & P6 & 0.886 & & & \\
\hline
\end{tabular}

\subsection{Results for the structural model}

In this section, we present the main results of this research. The use of the SEM allows better adjustment to the working frame than other techniques in more traditional analyses (linear regressions, for example), fundamentally for two reasons: i) SEM is a confirmatory and nonexploratory approach that allows previously theorized hypotheses to be contrasted; ii) its capacity to estimate multiple relations for each group of dependent variables. Fig. 2 shows the model with SEM notation.

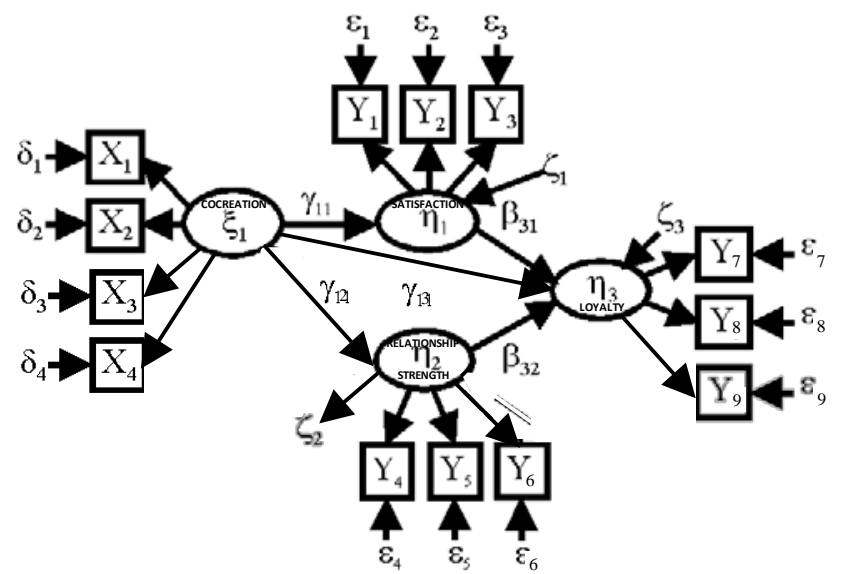


Fig. 2: Model of the effects of co-creation on relationship strength, satisfaction and loyalty

Overall, the model is judged to be a good fit with the data as most of the fit statistics are comfortably within acceptable levels. As shown at the bottom of Table 4, for example, the comparative fit index (CFI) is close to 1. Furthermore, the root mean squared error of approximation (RMSEA), a fit index adjusted for degrees of freedom, is lower than 0.08 , which is the level suggested by Browne and Cudeck (1993).

Table 4: Structural model results - estimates and model fit

$\begin{array}{ll}\text { Hypothesis } & \text { Standardize S.E. p value } \\ & d \\ & \text { coefficients }\end{array}$

$(\beta)$

\section{Direct effects}

Cocreation $\rightarrow$ Satisfaction

(y11)

Satisfaction $\rightarrow$ Loyalty $(\beta 31)$

Cocreation $\rightarrow$ Loyalty $(\gamma 13)$

0.860

$0.086<0.001$

Cocreation $\rightarrow$ Strength $(\mathrm{\gamma} 12)$

$\mathrm{H} 2$

0.301

0.133

$\mathrm{H} 3$

0.383

0.199

0.018

Strength $\rightarrow$ Loyalty $(\beta 32)$

$\mathrm{H} 4$

0.768

0.094

0.015

model fit indices

CMIN/DF

$\mathrm{H} 5$

0.084

$0.090 \quad 0.369$

$\mathrm{CFI}$

$1.524(<3)$

GFI

$0.982(>0.95)$

$0.910(\sim 0.95)$

AGFI

$0.864(>0.80)$

SRMR

$0.091(\sim<0.08)$

RMSEA

$0.036(<0.08)$

*Thresholds of acceptability of indices of quality, source: Hair, Black, Babin, and Anderson (2010).

In addition to the overall statistical fit of the model, it also explains a reasonable amount of the variance in each of the relationship outcome variables, satisfaction, loyalty and strength. Half the variance in the loyalty variable (squared multiple correlation $(\mathrm{SMC})=53 \%$ ) is explained by the direct direct and indirect effects of co-creation, satisfaction and strength. More than half the variance of strength $(\mathrm{SMC}=59 \%)$ is explained by the direct effect of co-creation. An even greater proportion of the variance in the satisfaction variable $(S M C=74 \%)$ is explained by the direct effect of the co-creation variable.

Therefore, co-creation has a significant and positive impact on satisfaction ( $\mathrm{y} 11=0.860, \mathrm{p}$-value $<0.001)$, as several authors have already stressed in the past (Dong, Evans, \& Zou, 2008 Grissemann \& StokurgerSauer, 2012; Lee et al, 2012; Shaw et al., 2011). 
As far as relations between the variables are concerned, except for that between relationship strength (university and student) and loyalty, which has a coefficient $\beta 32$ of 0.08 and a $p$-value $>0.05$, the others are all statistically significant and positive, as indicated by the p-values associated with the regression coefficients. The relations between co-creation and satisfaction and that between co-creation and strength are the two strongest (coefficients $\mathrm{Y} 11$ and $\mathrm{Y} 12$ of 0.860 and 0.768 , respectively, and significant at the $99 \%$ level), being both significant and positive, as also highlighted by several authors in the past (Bendapudi \& Leone, 2003; Dong, Evans, \& Zou, 2008; rissemann \& Stokurger-Sauer 2012; Lee, 2012; Shaw et al., 2011). On the other hand, the relations between satisfaction and loyalty and co-creation and loyalty are weaker (coefficients $\beta 31$ and $\mathrm{\gamma} 13$ being 0.301 and 0.383 , respectively, and significant at the $95 \%$ level).

To complete the analysis of $\mathrm{H} 3$, mediation must be tested. As Baron and Kenny (1986) point out, to establish mediation, one has to show that: (1) the relationship between the initial variable, co-creation, and the outcome variable, loyalty, is significantly correlated (a); (2) the initial variable is correlated with the mediator, satisfaction or strength (c); (3) the mediator, satisfaction or strength, affects the outcome variable, loyalty (d); (4) the effect of the initial variable, cocreation, on the outcome variable, loyalty (b), decreases in both significance and magnitude when the mediator is added to the model. As shown in Table 5, the mediation of satisfaction in the relation between co-creation and loyalty is partial, so that the direct influence between co-creation and loyalty is reduced by almost half in the presence of satisfaction. On the other hand, there is no mediation from satisfaction in the relation between co-creation and loyalty as the indirect effect is not significant ( $p$-value $>0.05$ ).

Table 5: Mediation

\begin{tabular}{lllll} 
Relation & $\begin{array}{l}\text { Direct } \\
\text { without } \\
(\mathrm{a})\end{array}$ & $\begin{array}{r}\text { effect } \\
\text { mediator }\end{array}$ & $\begin{array}{l}\text { Direct } \\
\text { with mediator } \\
(\mathrm{b})\end{array}$ & $\begin{array}{l}\text { Indirect effect } \\
\left(\mathrm{c}^{\star} \mathrm{d}\right)\end{array}$ \\
\hline $\begin{array}{l}\text { Co-creation- } \\
\text { satisfaction-loyalty } \\
\begin{array}{l}\text { Co-creation- } \\
\text { strength-loyalty }\end{array}\end{array}$ & $0.700(<0.001)$ & $0.409(<0.001)$ & $\begin{array}{l}0.292 \\
\text { partial }\end{array}$ & $(0.024)$ \\
& $0.700(<0.001)$ & $0.585(<0.001)$ & $\begin{array}{l}0.116(0.160) \text { No } \\
\text { mediation }\end{array}$ \\
\hline
\end{tabular}

\section{Conclusions and Contributions}

This research is innovative both due to its setting in the B2B context - a university-company-employee value co-creation process - and due to the fact that these relationships between the outlined constructs have never before been suggested by means of a quantitative study in the postgraduate educational sector. It has allowed us to promote the use of marketing theories such as value co-creation to be considered by the very universities in which these concepts are typically taught. Our overall contribution is to provide evidence of the positive effect of this $\mathrm{B} 2 \mathrm{~B}$ value creation process for educational 
institutions and their customers (managers/companies) in the postgraduate market.

This study has validated part of our proposed model. Our findings alert institutions to how value co-creation affects satisfaction and future loyalty towards the institution. At the same time, our quantitative research also shows that relationship strength is a positive influence in this value creation process, but does not mediate between co-creation and loyalty.

This B2B value co-creation process, in which managers participate in cocreation with the university, leads to higher levels of satisfaction and to greater loyalty to the educational institution by adult students. Consequently, it can be stated that all the efforts of educational institutions aimed at the greater involvement of adult student-managers as value co-creators of the service will result in greater satisfaction and loyalty to the institution. The potential consequences of enhanced customer loyalty to universities are increased revenues, reduced customer acquisition costs, and lower costs of serving repeat purchasers, thus resulting in greater profitability as stated by Reichheld (1992) in his study of the consequences of loyalty.

Therefore, our research proves to be a helpful tool that can help universities benefit from the potential of co-creation, enabling them to develop a competitive strategy that will generate more value for their clients and will also be difficult for the competition to imitate, a point made by Cova et al. (2011) in relation to developing differentiation strategies .

Future studies should both further explore and replicate the model with undergraduate students (business-to-consumer value co-creation), an aspect of provision where loyalty is even more strategic for educational institutions. Also, they should consider gender aspects, comparing the results for males vs. females and investigating whether there are any differences. 


\section{APPENDIX A}

Thinking about your experience with this university, please indicate your agreement/disagreement with the following statements, using the scale from "strongly disagree" (1) to "strongly agree" (7)

q1 1 would highly recommend this university

q2 I am likely to make positive comments about this univeristy to my friends and colleagues

q3 $\quad$ In the future, I intend to return to this university to continue with my studies

q4 $\quad$ The probability that I will consider this university again in the future is very high

q5 As long as the present service continues, I doubt that I would change my university

q6 I intend to continue using this university for some time

q7 $\quad$ If the service is the same, I doubt I would return to this university

q8 $\quad$ My relationship with this university is very important to me

q9 $\quad$ My relationship with this university is very strong

q10 My relationship with this university is something I really care about

q11 Overall, I am pleased with the services offered by this university

q12 The service offered by my university meets my expectations

q13 I think I did the right thing when I enrolled in this university

q14 In our relationship, my university has high integrity

q15 In our relationship, my university can be counted on to do what is right

q16 In our relationship, my university can be trusted at all times...

We are interested in the concept of "customer co-creation," which occurs when a company and its customers work together to create a (purchase) solution. Now, please consider the passage we have just read responding to the statements using the same scale from "strongly disagree" (1) to "strongly agree" (7), as before.

q17 What I receive from this university is due to work jointly between the university and student

q18 Overall, I would describe my relationship with this university as involving a high level of co-creation

q19 This university tries to ensure that the final service solution is due to the work of both university and student 
q20 The final purchase solution was arrived at mainly through the joint effort, the university and myself

q21 I contribute actively to the final solution in the educational service I receive 


\section{References}

Arnett DB, German SD, Hunt SD. (2003). The identity salience model of relationship marketing success: The case of nonprofit marketing. J Market;67(2):89-105.

Auh S, Bell SJ, McLeod CS, Shih E. (2007) Co-production and customer loyalty in financial services. J Retail;83(3):359-370.

Ballantyne, D., Frow, P., Varey, R. J., \& Payne, A. (2011). Value propositions as communication practice: Taking a wider view. Industrial Marketing Management, 40(2), 202210.

Baron, R. M., \& Kenny, D. A. (1986). The moderatormediator variable distinction in social psychological research: Conceptual, strategic, and statistical considerations. Journal of personality and social psychology, 51(6), 1173.

Basole, R. C., \& Rouse, W. B. (2008). Complexity of service value networks: conceptualization and empirical investigation. IBM systems journal, 47(1), 53-70.

Bove, L. L., \& Johnson, L. W. (2001). Customer relationships with service personnel: do we measure closeness, quality or strength?. Journal of Business Research, 54(3), 189-197.

Bovill, C., Cook-Sather, A., \& Felten, P. (2011). Students as co-creators of teaching approaches, course design, and curricula: implications for academic developers. International Journal for Academic Development, 16(2), 133-145. 
Boyle, E. (2007). A process model of brand cocreation: brand management and research implications. Journal of Product \& Brand Management, 16(2), 122-131.

Bowden JL, D'Alessandro S.(2011) Co-creating value in higher education: The role of interactive classroom response technologies. Asian social science;7(11):p35.

Browne, M. W., \& Cudeck, R. (1993). Alternative ways of assessing model fit.Sage Focus Editions, 154, 136-136.

Caceres, R. C., \& Paparoidamis, N. G. (2007). Service quality, relationship satisfaction, trust, commitment and business-to-business loyalty. European Journal of Marketing, 41(7/8), 836-867.

Carvalho SW, de Oliveira Mota M. (2010). The role of trust in creating value and student loyalty in relational exchanges between higher education institutions and their students. Journal of Marketing for Higher Education;20(1):145-165.

Chesbrough, H. W. (2003). Open innovation: The new imperative for creating and profiting from technology. Harvard Business Press.

Chinomona R, Sandada M. (2013).Service Quality Level as the Determinant of Consumer Emotional Loyalty and Fantasy in South Africa's Pick \& Pay Chain Stores. Mediterranean Journal of Social Sciences;4(3):579.

Cova B, Dalli D, Zwick D. (2011).Critical perspectives on consumers' role as 'producers': Broadening the debate on value co-creation in marketing processes. Marketing Theory;11(3):231-241.

Cronbach LJ. (1951).Coefficient alpha and the internal structure of tests. Psychometrika;16(3):297-334. 
Cugini, A., Caru, A., \& Zerbini, F. (2007). The cost of customer satisfaction: a framework for strategic cost management in service industries. European Accounting Review, 16(3), 499-530.

Dong B, Evans KR, Zou S. (2008). The effects of customer participation in co-created service recovery. Journal of the Academy of Marketing Science;36(1):123-137.

Edmonds, A. (2008). Customer loyalty through co-creation in an independent retail setting. Otago Marketing Review, 1, 1-4.

Enache, I. C. (2011). Marketing higher education using the 7 Ps framework.Bulletin of the Transilvania University of Braşov• Vol, 4(53).

Fornell C, Larcker DF. (1981).Evaluating structural equation models with unobservable variables and measurement error. J Market Res:39-50.

Fredberg, T., Elmquist, M., \& Ollila, S. (2008). Managing Open InnovationPresent Findings and Future Directions.

Geyskens, I., Steenkamp, J. B. E., \& Kumar, N. (1999). A meta-analysis of satisfaction in marketing channel relationships. Journal of marketing Research, 223-238.

Giner GR, Peralt A. (2014).Métodos y técnicas facilitadoras de la co-creation innovation en programas máster para el mercado del postgrado. Intangible Capital;10(1).

GMAC Survey (2010).Graduate Management Admission Council

Grissemann US, Stokburger-Sauer NE.(2012) Customer co-creation of travel services: The role of company 
support and customer satisfaction with the co-creation performance. Tourism Management;33(6):1483-1492.

Gustafsson A, Kristensson P, Witell L. (2012).Customer co-creation in service innovation: a matter of communication Journal of Service Management;23(3):311-327.

Jaakkola, E., \& Hakanen, T. (2013). Value co-creation in solution networks. Industrial Marketing Management, 42(1), 47-58.

Haas, A., Snehota, I., \& Corsaro, D. (2012). Creating value in business relationships: The role of sales. Industrial Marketing Management, 41(1), 94-105.

Hair J, Black W, Babin B, Anderson R. (2010).Multivariate data analysis. 7th ed2010.

Hair JF, Suárez MG. (1999). Análisis multivariante. : Prentice Hall Madrid.

Hasche, N. (2006). Developing collaborative customersupplier relationships through value co-creation.

Helgesen $\varnothing$ (2008). Marketing for higher education: A relationship marketing approach. Journal of Marketing for Higher Education;18(1):50-78.

Hennig-Thurau T, Malthouse EC, Friege C, Gensler S, Lobschat L,. (2010). The impact of new media on customer relationships. Journal of Service Research;13(3):311-330.

Hoyer WD, Chandy R, Dorotic M, Krafft M, Singh SS. (2010).Consumer cocreation in new product development. Journal of Service Research;13(3):283-296. 
Kotler, P., \& Fox, K. F. (1995). Strategic marketing for educational institutions.

Kotler, P. (2001). Marketing Management Pearson Education.

Kotze TG, Du Plessis P.(2003) Students as "co-producers" of education: a proposed model of student socialisation and participation at tertiary institutions. Quality Assurance in Education;11(4):186-201.

Lam, S. Y., Shankar, V., Erramilli, M. K., \& Murthy, B. (2004). Customer value, satisfaction, loyalty, and switching costs: an illustration from a business-to-business service context. Journal of the Academy of Marketing Science, 32(3), 293-311.

Lee SM, Olson DL, Trimi S. (2012).Co-innovation: convergenomics, collaboration, and co-creation for organizational values. Management Decision;50(5):817831.

Lusch, R. F., Vargo, S. L., \& Tanniru, M. (2010). Service, value networks and learning. Journal of the Academy of Marketing Science, 38(1), 19-31.

Mai, L. W., \& Ness, M. R. (2006). A structural equation model of customer satisfaction and future purchase of mail-order speciality food. International Journal of Business Science and Applied Management, 1(1), 1-13.

Maringe, F., \& Gibbs, P. (2009). Marketing higher education: Theory and practice. McGraw-Hill International.

Marzo-Navarro M, Pedraja-Iglesias M, Rivera-Torres MP. (2005).Measuring customer satisfaction in summer courses. Quality Assurance in Education;13(1):53-65. 
Mavondo FT, Tsarenko Y, Gabbott M. (2004).International and local student satisfaction: resources and capabilities perspective. Journal of Marketing for Higher Education;14(1):41-60.

Mattila, A. S. (2006). How affective commitment boosts guest loyalty (and promotes frequent-guest programs). Cornell Hotel and Restaurant Administration Quarterly, 47(2), 174-181.

Meng, S. M., Liang, G. S., \& Yang, S. H. (2011). The relationships of cruise image, perceived value, satisfaction, and post-purchase behavioral intention on Taiwanese tourists. African Journal of Business Management, 5(1), 19-29.

Mintzberg, H., \& Gosling, J. (2002). Educating managers beyond borders.Academy of Management Learning \& Education, 1(1), 64-76.

Moore D, Bowden-Everson JL. (2012).An Appealing Connection-The Role of Relationship Marketing in the Attraction and Retention of Students in an Australian Tertiary Context. Asian Social Science;8(14):p65.

Nam, K., \& Lee, N. H. (2010). Typology of Service Innovation from Service-Dominant Logic Perspective. J. UCS, 16(13), 1761-1775.

Ng, I. C., \& Forbes, J. (2009). Education as service: the understanding of university experience through the service logic. Journal of Marketing for Higher Education, 19(1), 3864.

Nicholls, J., Harris, J., Morgan, E., Clarke, K., \& Sims, D. (1995). Marketing higher education: the MBA experience. International Journal of Educational Management, 9(2), 31-38. 
Nicolescu, L. (2009). Applying marketing to higher education: Scope and limits.Management \& Marketing, 4(2), 35-44.

Nunnally J. C.(1978). Psychometric theory. 1978.

Piller F, Ihl C, Vossen A. Customer co-creation: Open innovation with customers. Wittke, V./Hanekop, H 2011:31-63.

Prahalad CK, Ramaswamy V. (2000); Co-opting customer competence. Harv Bus Rev 78(1):79-90.

Rajah E, Marshall R, Nam I. (2008).Relationship glue: customers and marketers co-creating a purchase experience. Advances in Consumer Research;35:367-373.

Ramaswamy, V. (2009). Leading the transformation to cocreation of value.Strategy \& Leadership, 37(2), 32-37.

Reichheld, F. F. (1992). Loyalty-based management. Harvard business review,71(2), 64-73.

Schimmel, K., Eschenfelder, M., Clark, J., Marco, G., \& Racic, S. (2011). Differences in selection criteria among traditional students, adult continuing education students and graduate students. American Journal of Business Education (AJBE), 2(5).

Shaw G, Bailey A, Williams A. (2011).Aspects of servicedominant logic and its implications for tourism management: Examples from the hotel industry. Tourism Management;32(2):207-214.

Sheth, J. N. (1973). A model of industrial buyer behavior. The Journal of Marketing, 50-56. 
Storbacka K, Strandvik T, Grönroos C. (1994).Managing customer relationships for profit: the dynamics of relationship quality. International journal of service industry management;5(5):21-38.

Temple, P. (2009). From space to place: University performance and its built environment. Higher Education Policy, 22(2), 209-223.

Ulaga, W. (2011). Investigating customer value in global business markets: Commentary essay. Journal of Business Research, 64(8), 928-930.

Vargo, S. L., \& Lusch, R. F. (2008). Service-dominant logic: continuing the evolution. Journal of the Academy of marketing Science, 36(1), 1-10.

Veloutsou, C., Lewis, J. W., \& Paton, R. A. (2004). University selection: information requirements and importance. International Journal of Educational Management, 18(3), 160-171.

Verhoef, P. C. (2003). Understanding the effect of customer relationship management efforts on customer retention and customer share development.Journal of marketing, 67(4), 30-45.

Yi, Y., \& Gong, T. (2013). Customer value co-creation behavior: Scale development and validation. Journal of Business Research, 66(9), 1279-1284.

Zander, I., \& Zander, U. (2005). The Inside Track: On the Important (But Neglected) Role of Customers in the Resource-Based View of Strategy and Firm Growth*. Journal of Management Studies, 42(8), 15191548. 
Zhang JQ, Dixit A, Friedmann R. (2010)Customer loyalty and lifetime value: an empirical investigation of consumer packaged goods. The Journal of Marketing Theory and Practice;18(2):127-140. 


\section{CAPÍTULO 7}

CONCLUSIONES 


\section{1.- Conclusiones}

En la primera parte de esta tesis, la reflexión se ha centrado en la necesidad que tienen las instituciones educativas, en un momento complejo como el actual, de lograr una mayor orientación hacia el mercado para poder desarrollar estrategias competitivas diferenciadoras en el mercado de los másteres. La falta de estudios sobre el posgrado es todavía más llamativa si se tiene en cuenta que el Tratado de Bolonia incrementa el interés por parte de las universidades en los másteres al considerarlos en muchos casos como un paso previo para poder ejercer determinadas profesiones o para completar los estudios de grado. Todo ello redunda en un mercado con una mayor competencia y al mismo tiempo, en una necesidad de más pensamiento estratégico para las propias universidades.

Esta necesidad de una mayor orientación hacia el mercado en el caso de los cursos de posgrado, ha sido claramente identificada en la revisión de la literatura. La estrategia de orientación al mercado requiere, como primera fase, el desarrollo de un modelo de toma de decisiones del estudiante adulto ante la elección de un programa de máster. La revisión de la literatura ha evidenciado que ese modelo no está desarrollado. Por eso, nuestra primera aportación con esta tesis ha sido la propuesta de un modelo que explique de forma muy detallada el proceso de decisión del estudiante de posgrado, así como las interrelaciones que existen entre universidad, estudiante adulto y empresa. Este modelo se ha desarrollado como primer paso para una orientación proactiva hacia el mercado de posgrado y ha demostrado la importancia de considerar las interrelaciones e influencias entre los tres actores implicados: universidad estudiante adulto - empresa. 
Tras desarrollar un modelo explicativo del proceso de toma de decisiones del estudiante adulto y poner de manifiesto la existencia de los tres actores que interactúan en este proceso, la tesis introduce la co-creation como fórmula para avanzar en esa mayor orientación al mercado En la revisión de la literatura se comprueba que existe escasa investigación al respecto en el sector educativo y que es prácticamente inexistente en el área del posgrado. Por eso, la segunda aportación de la tesis fue la propuesta de un marco que facilitase la innovación en el mercado de posgrado bajo el paradigma de la cocreación y que implicase la participación de los diversos actores (universidad, estudiante adulto y empresa). El modelo propuesto ofrece, bajo el paradigma de la cocreación, diferentes tipos posibles de innovaciones futuras que las instituciones de posgrado pueden considerar con el objetivo de diferenciarse claramente en este mercado. Este modelo fue contrastado a través de un estudio Delphy con expertos para introducirle mejoras, lo que dio lugar al modelo definitivo propuesto.

El principal punto diferenciador de nuestro modelo es la involucración de los diferentes actores implicados en el posgrado. Esto supone una clara apuesta por una orientación proactiva hacia el mercado en la que el estudiante adulto y los empleadores participan activamente junto con la universidad en el proceso de la co-creación de valor, en la búsqueda de un beneficio para todos y en definitiva, en una mayor satisfacción de sus intereses por ser partícipes activos de esas propuestas innovadoras. En resumen, con este modelo o marco, se pretende facilitar a las universidades el camino hacia una innovación con éxito a través del uso de la co-creation focalizada en las distintas posibilidades de innovación. Todo ello, aumenta la probabilidad de que las instituciones educativas logren estrategias diferenciadoras aplicando técnicas del marketing ya superadas en otros sectores. 
En la siguiente fase de la tesis, se da continuidad al uso de la co-creation por parte de las universidades aunque desde el punto de vista de su implementación. Para ello, se revisan las distintas técnicas y métodos utilizados en otros sectores lográndose una clasificación de los mismos. Tras el análisis se ha visto que los Living lab combinados con la involucración de lead users son las técnicas más idóneas para plantear con éxito un proceso de co-creation en instituciones educativas.

Finalmente, en la última parte de la tesis y se realizaron dos estudios cuantitativos a través de modelos de ecuaciones estructurales, donde se abordaron las consecuencias de llevar a cabo un proceso de co-creation sobre distintos outputs del marketing: satisfacción, relación y lealtad del alumno hacia la institución.

Estos estudios cuantitativos se han realizado bajo una doble perspectiva, la de business to consumer (cuando el alumno era universitario) y la de business to business (cuando el alumno era un profesional enviado por su empresa para realizar el máster). En el primer trabajo, se evalúa la influencia de un proceso de cocreation en la satisfacción y lealtad hacia la universidad del propio alumno que participa. El estudio concluye que la co-creation influye en la satisfacción y la lealtad del estudiante hacia la universidad de manera positiva, por lo que se puede considerar una buena estrategia de fidelización.

En el segundo trabajo, se plantea un modelo con más constructos donde se ha añadido la variable fortaleza de la relación, se llega a la conclusión final de que, para los profesionales enviados por sus empresas, la participación en procesos de co-creation influye en la satisfacción y lealtad del estudiante y en la fortaleza de la relación aunque sin mediar para potenciar la lealtad del estudiante. 
En esta parte final de la tesis se evidencia desde un punto de vista cuantitativo, que los procesos de cocreation son en sí mismos estrategias de marketing diferenciadoras al potenciar la lealtad del estudiante de posgrado con independencia de los resultados mismos de esa co-creation.

Así pues, en esta tesis no sólo se han identificado las posibilidades que ofrece la co-creation para las universidades, así como las mejores técnicas y métodos para aplicarla junto con un marco que detalle todas sus posibilidades, sino que además se ha demostrado que el propio proceso de co-creation tiene efectos positivos sobre la lealtad del estudiante. En definitiva, se ha logrado demostrar que la co-creation puede ser una fuente doble de ventaja competitiva para las instituciones educativas: una mejora de las innovaciones en distintas perspectivas, y una mejora de la satisfacción del estudiante de posgrado.

\section{2.-Limitaciones}

Las limitaciones de este estudio son, por una parte, la necesidad de introducir en nuestro modelo sobre la cocreation la opinión de las instituciones gubernamentales educativas que establecen los estándares de educación y cuya opinión debe ser considerada en este proceso de alguna manera.

Por otra parte, en cuanto al estudio cuantitativo, las limitaciones de este estudio son básicamente debidas a las restricciones de la base de datos utilizada debiéndose ampliar a un número mayor de universidades y programas. Por último, el estudio cuantitativo no ha considerado la variable de género por si pudiera tener alguna influencia en los resultados 


\section{3.- Futuras líneas de investigación}

En el futuro, proponemos analizar desde estudios cuantitativos cuales podrían ser los enfoques concretos donde centrar los proyectos de co-creación dentro de las distintas posibilidades que el modelo planteado nos ofrece. En este sentido, será necesario considerar tanto las necesidades de las universidades como también aquello que resulta más determinante y discriminante para el alumno, algo que en sí mismo ya es de interés para las universidades.

También consideramos como acción futura de investigación el realizar un estudio en profundidad de tipo cualitativo para obtener más información sobre cómo llevar a cabo la implantación de la técnica living lab de la manera más adecuada en este contexto.

Como conclusión, señalar que esta tesis ha iniciado un camino sobre las posibilidades de la cocreación para el mercado de posgrado. Además coincide con un momento donde los cambios legislativos, Ley Wert, van a influir de manera determinante en la importancia que las universidades le tienen que otorgar a los estudios de posgrado cuya interés por parte de los alumnos universitarios se deberá ver incrementado. Consecuentemente, La combinación de investigaciones centradas en los estudiantes preuniversitarios y de master será fundamental.

Por todo ello, esperamos que esta tesis sea el inicio para lograr promover y desarrollar este campo de la co-creación para las instituciones educativas en su mercado de posgrado. 
ANEXOS 
PUBLICACIONES 
PUBLICACIÓN PAPER 1: Publicado

Revista Dirección y Organización (DYO) 
wwwrevistadyo.com

\title{
A proactive market orientation for the postgraduate programs Una orientación proactiva hacia el mercado para los programas de Postgrado
}

\author{
Agustín Peralt Rillo', Gabriela Ribes-Giner? \\ ' Departamento de Organización de Empresa,Universidad Europea de Valencia.Valencia.España. \\ ${ }^{2}$ Departamento Organización de Empresas, Facultad de Administración y dirección de empresas. Universidad Politécnica de Valencia (U.P.V). \\ Camino de Vera, s/n 46022 Valencia. España \\ agustin.peraltQuem.es, gabrigi@omp.upv.es
}

Fecha de recepción: 4-1-2013

Fecha de aceptación: 18-2-2013

Abstract: The present study aims to help universities to develop a proactive market orientation as the precedent for a successful innovation policy for their postgraduate programs through a deep review of the concepts of "proactive market orientation" of the postgraduate market and its relative "postgraduate decision-making process".

This 'decision-making process model' will be the perfect framework which will facilitate different reflections about customers (adult students), companies (employers) and universities and all their possible interactions which can exist under a "proactive market orientation" and the consequent strategies for a successful innovation policy.

Therefore, this research makes a significant contribution to the body of knowledge in this important area of market orientation as a precedent for innovation for educational institutions This proactive market research philosophy can assist the University administrators, managers and recruiters in adapting their marketing strategies and their related innovation policy in order to differentiate from the competition in a complex sector like the postgraduate education one.

Keywords: proactive market orientation, innovation, postgraduate, masters programs.

Resumen: El presente estudio pretende ayudar a las universidades a desarrollar una orientación proactiva hacia el mercado como precedente de una política de innovación exitosa para sus programas máster, a través de una revisión sistemática de los conceptos de «orientación proactiva hacia el mercado del postgrado» y su correspondiente uproceso de toma de decisiones y eleccións.

El modelo de proceso de elección será el marco perfecto para facilitar reflexiones sobre consumidores (estudiantes adultos). compañías (empleadoras o facilitadoras de alumnos), universidades y todas las posibles relaciones que existan relacionadas con la orientación proactiva hacia el mercado y sus consecuentes estrategias en la búsqueda de una política de innovación exitosa. Por lo tanto, esta investigación realiza una significante contribución al conocimiento en el área de la orientación al mercado como un precedente para la innovación en las instituciones educativas. Esta filosofía de orientación proactiva hacia el mercado puede ayudar a las universidades, sus administradores, sus directivos y sus recruiters a adaptar sus estrategias de marketing y su correspondiente política de innovación para poder diferenciarse de la competencia en un sector tan complejo como el de la educación de postgrado

Palabras clave: orientación proactiva, innovación, postgrado, programas máster.

\section{Introduction. Trends in the market of postgraduate education}

In this paper, the "decision-making process for postgraduate education" will refer to the process by which an adult makes the determination to enroll in a parttime postgraduate program, a part-time master.

In this introductory section, we are going to review the present situation of the postgraduate market.
The postgraduate education institutions are facing an increasingly complex competition due to today's tough economic situation, the global economy and the introduction of online education programs and institutions all around the world (Schimel et al 2009). This increasing competition among postgraduate providers is now driving the need for an improved more thorough understanding of the students "decisionmaking behaviors" (Jarvis, 2000; Riana et al 2006). Indeed, as mentioned before, in Europe, the Bologna 


\section{PUBLICACIÓN PAPER 2 : Publicado}

Capitulo 13 Libro Innovation and Teaching Technologies. Editorial: Springer

Co-creation Innovation model for masters programs in the universities

2014, pp 117-125

Date: 05 Mar 2014 


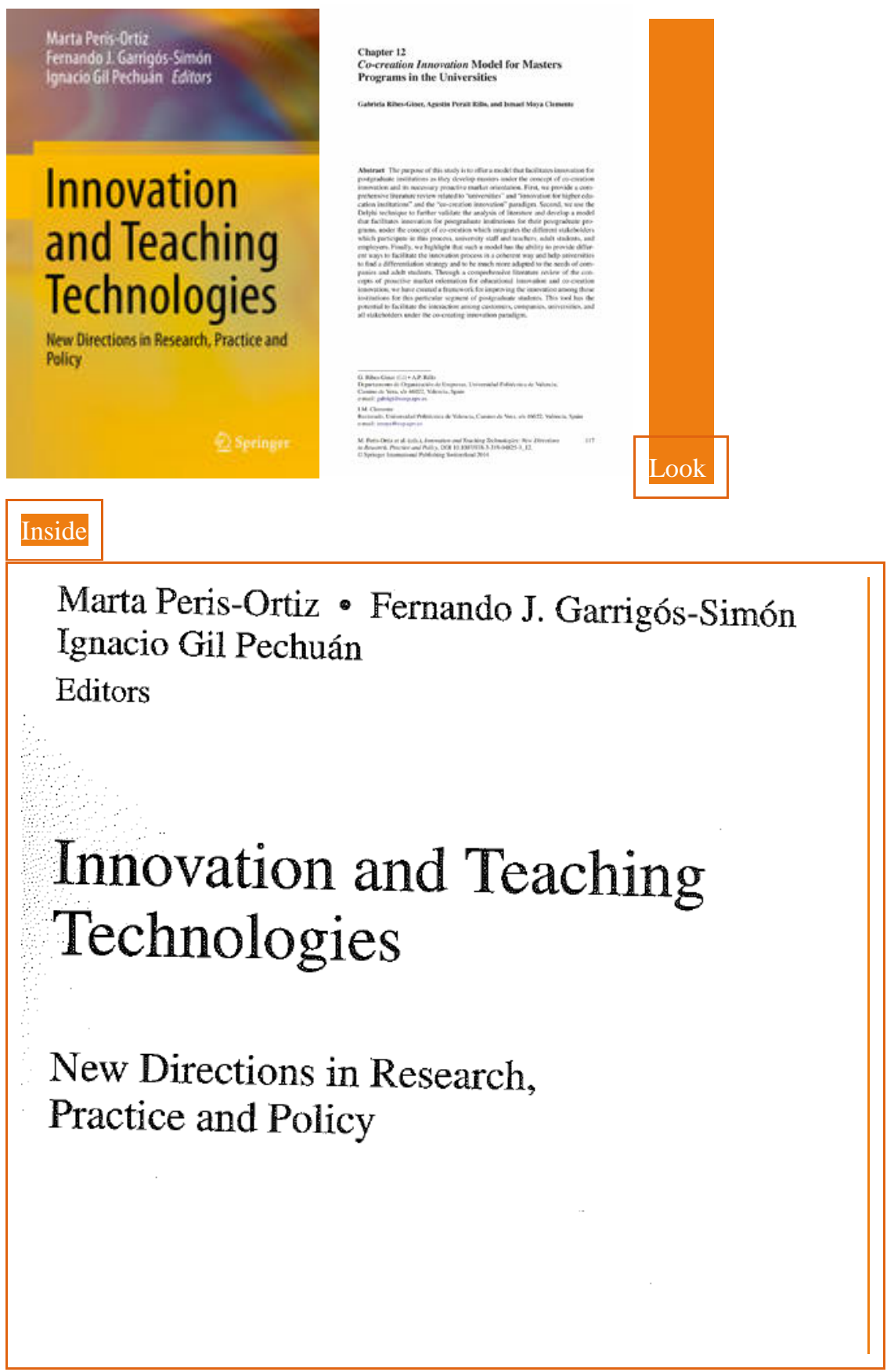


ISBN 978-3-319-04824-6

ISBN 978-3-319-04825-3 (eBook)

DOI $10.1007 / 978-3-319-04825-3$

Springer Cham Heidelberg New York Dordrecht London

Library of Congress Control Number: 2014934152

(c) Springer International Publishing Switzerland 2014

This work is subject to copyright. All rights are reserved by the Publisher, whether the whole or part of the material is concerned, specifically the rights of translation, reprinting, reuse of illustrations, recitation, broadcasting, reproduction on microfilms or in any other physical way, and transmission or information storage and retrieval, electronic adaptation, computer software, or by similar or dissimilar methodology now known or hereafter developed. Exempted from this legal reservation are brief excerpts in connection with reviews or scholarly analysis or material supplied specifically for the purpose of being entered and executed on a computer system, for exclusive use by the purchaser of the work. Diplication of this publication or parts thereof is permitted only under the provisions of the Copyright Law of the Publisher's location, in its current version, and permission for use must always be obtained from Springer Permissions for use may be obtained through RightsLink at the Copyright Clearance Center. Violations are liable to prosecution under the respective Copyright Law.

The use of general descriptive names, registered names, trademarks, service marks, etc. in this publication does not imply, even in the absence of a specific staternent, that such names are exempt from the relevant protective laws and regulations and therefore free for general use.

While the advice and information in this book are believed to be true and accurate at the date of publication, neither the authors nor the editors nor the publisher can accept any legal responsibility for any errors or omissions that may be made. The publisher makes no warranty, express or implied, with respect to the material contained herein.

Printed on acid-free paper

Springer is part of Springer Science+Business Media (www.springer,com) 


\title{
Chapter 12 \\ Co-creation Innovation Model for Masters Programs in the Universities
}

\author{
Gabriela Ribes-Giner, Agustin Peralt Rillo, and Ismael Moya Clemente
}

\begin{abstract}
The purpose of this study is to offer a model that facilitates innovation for postgraduate institutions as they develop masters under the concept of co-creation innovation and its necessary proactive market orientation. First, we provide a comprehensive literature review related to "universities" and "innovation for higher education institutions" and the "co-creation innovation" paradigm. Second, we use the Delphi technique to further validate the analysis of literature and develop a model that facilitates innovation for postgraduate institutions for their postgraduate programs, under the concept of co-creation which integrates the different stakeholders which participate in this process, university staff and teachers, adult students, and employers. Finally, we bighlight that such a model has the ability to provide different ways to facilitate the innovation process in a coherent way and help universities to find a differentiation strategy and to be much more adapted to the needs of companies and adult students. Through a comprehensive literature review of the concepts of proactive market orientation for educational innovation and co-creation innovation, we have created a framework for improving the innovation among those institutions for this particular segment of postgraduate students. This tool has the potential to facilitate the interaction among customers, companies, universities, and all stakeholders under the co-creating innovation paradigm.
\end{abstract}

\footnotetext{
G. Ribes-Giner $(\varangle) \cdot$ A.P. Rillo

Departamento de Organización de Empresas, Universidad Politécnica de Valencia,

Camino de Vera, s/n 46022 , Valencia, Spain

e-mail: gabrigi@omp.upv.es
}

I.M. Clemente

Rectorado, Universidad Politécnica de Valencia, Camino de Vera, s/n 46022, Valencia, Spain

e-mail: imoya@esp.upv.es 


\section{PUBLICACIÓN PAPER 3: Publicado \\ Revista : Intangible Capital}

\section{Métodos y técnicas facilitadoras de la co-creation innovation en programas máster para el mercado del postgrado}

Gabriela Ribes Giner, Agustín Peralt

\section{Resum}

Purpose: The main objective of this paper is to propose methods and techniques for successfully implementing an innovative project based on the paradigm of co -creation innovation for the postgraduate market. This is intended to provide universities the way to a successful innovation policy in its masters programs which are understood as a product-service binomial.

Design/methodology/approach: The methodology used is a review of the literature in innovation co-creation.

Contributions/results: We have identified best practices in innovation co-creation in other sectors, and the different methods and techniques used with good results. Furthermore, these methods and techniques were classified depending on the dimensionality of the co -creation innovation.

Practical implications: This study proposes the most appropriate methods and techniques for an educational institution to implement an innovation project for their master programs based on the paradigm of CO

-creation.

Originality/value: This study facilitates universities, the road to a successful innovation policy in its formative offer Master programs through the paradigm of co-creation. This innovation process based on the co-creation requires active collaboration between the different parties involved in this process: the adult student, employer -firms and the staff of the university, which is the training service provider 


\section{PUBLICACIÓN PAPER 4 : Aceptada. Pendiente de publicación. \\ Revista: Journal of Computational and Applied Mathematics}

\begin{tabular}{|l|l|l|l|}
\hline Category Name & $\begin{array}{l}\text { Total } \\
\text { Journals } \\
\text { in Category }\end{array}$ & $\begin{array}{l}\text { Journal } \\
\text { Rank } \\
\text { in Category }\end{array}$ & $\begin{array}{l}\text { Quartile } \\
\text { in } \\
\text { Category }\end{array}$ \\
\hline $\begin{array}{l}\text { MATHEMATICS, } \\
\text { APPLIED }\end{array}$ & 251 & 70 & Q2 \\
\hline
\end{tabular}

23-02-2015Ms. $\quad$ Ref. $\quad$ No.: $\quad$ CAM-D-14-01753R2

Title: Structural equation modeling of co-creation and its influence on the student's satisfaction and loyalty towards university Journal of Computational and Applied Mathematics

Dear

Mr.

PERALT,

I am pleased to confirm that your paper "Structural equation modeling of co-creation and its influence on the student's satisfaction and loyalty towards university" has been accepted for publication in Journal of Computational and Applied Mathematics.

Comments from the Editor and Reviewers can be found below. Thank you for submitting your work to this journal. With

kind

Lucas

Guest

Antonio

Journal of Computational and Applied Mathematics regards,

Sánchez,

$\mathrm{Ph}$ Editor 


\section{PUBLICACIÓN PAPER 5: En revisión.}

Revista: Industrial Marketing Management

\begin{tabular}{|l|l|l|l|}
\hline Category Name & $\begin{array}{l}\text { Total J ournals } \\
\text { in Category }\end{array}$ & $\begin{array}{l}\text { J ournal Rank } \\
\text { in Category }\end{array}$ & $\begin{array}{l}\text { Quartile } \\
\text { in Category }\end{array}$ \\
\hline BUSINESS & 111 & 35 & Q2 \\
\hline MANAGEMENT & 173 & 47 & Q2 \\
\hline
\end{tabular}

$16 / 11 / 14$

De: marko.kohtamaki@uwasa.fi

Para: agustin peralt ,

Thank you for your submission to the special issue on the "theory and practice of value co-creation in B2B systems" in Industrial Marketing Management.

Your manuscript will be processed after the submission deadline (15.11.2014).

All the best,

Marko Kohtamäki

Head of Department of Management

Professor, Ph.D. (econ.) / Visiting Professor 